\title{
39. JURASSIC AND CRETACEOUS CALCISPHAERULIDAE FROM DSDP LEG 27, EASTERN INDIAN OCEAN
}

\author{
Hans M. Bolli, Department of Geology, Swiss Federal Institute of Technology, \\ Zurich, and University of Zurich, Switzerland
}

\begin{abstract}
Nineteen new species and four forms in open nomenclature of Pithonella, here included in the incertae sedis family Calcisphaerulidae, are described from Upper Jurassic, Lower and Upper Cretaceous sediments recovered from Sites 259, 260, 261, and 263 of Leg 27 in the Eastern Indian Ocean. One genus, Andriella, is proposed as new. Previously, specimens of Calcisphaerulidae, which have an average size of $40-120 \mu$ were described exclusively from thin sections of limestones. The specimens from the Leg 27 sections could be isolated from the soft sediments and be studied by SEM methods. This led to the recognition of much more detail in wall structure (outside, inside, and cross-section views) than was previously possible.

Most specimens are spherical in shape, some more or less ovoid or distinctly elongate, all usually with an aperture. The walls are composed of one to three layers, consisting of calcite crystals of different size, shape, and arrangement. The systematic position is still uncertain, but there are some indications that the tests may represent a cyst stage, possibly of algae. The stratigraphic distribution of the individual Pithonella species described here is restricted. Once investigated by SEM methods in more complete and better dated sections, Calcisphaerulidae may well become valuable index fossils for the Jurassic and Cretaceous.
\end{abstract}

\section{INTRODUCTION}

Since the description of the first Pithonella species under the names Lagena ovalis and $L$. sphaerica by Kaufmann in Heer (1865), numerous Calcisphaerulidae species were published under a variety of generic names. The small, mostly spherical to ovate incertae sedis Calcisphaerulidae, known from the Jurassic and Cretaceous, have thus far almost exclusively been described from thin sections of limestones. Only recently have attempts been made to study isolated specimens under the light microscope (LM). Because of the limited resolution and depth of focus, however, the results have been unsatisfactory.

The application of the scanning electron microscope (SEM) technique, first applied by Banner (1972) and now in this paper, has allowed for the observation of features not previously seen in isolated specimens. The Leg 27 Cretaceous sediments, consisting largely of pelites from which isolated microfossils are readily recovered, have produced some of the best preserved and most diversified Calcisphaerulidae known so far.

Comparison of the Leg 27 isolated Calcisphaerulidae studied under the SEM with the published LM thin sections has not yet led to conclusive results because of the marked differences in resolution and viewed parts of specimens. Reliable comparison of the here-described species with published forms can eventually only be expected by using topotypic material and the same observation methods. During the short time available for the preparation of this paper, this was not possible. However, from some preliminary comparative work carried out on material from the East Indian Archipelago, and taking into consideration the stratigraphic position of the species already described, it would appear that only a very low percentage of the here-proposed species might eventually become synonyms of previously published forms.

Compared with other microfossil groups, relatively little attention has been paid so far to the biostratigraphic usefulness of the Calcisphaerulidae. The reasons for this are their small (40 to 60, occasionally to $120 \mu$ ) size and the fact that all known single-chambered and mostly spherical to ovoid species have been described from thin sections. However, from the published record, it is apparent that many of the distinguished species have restricted ranges and can be used in biostratigraphy. Some authors have published range charts and some have even proposed zones based on Calcisphaerulidae species.

That Calcisphaerulidae species have restricted ranges is also demonstrated in this study. Each of the 19 Pithonella isolated species and four forms of open nomenclature, here distinguished based on test shape, aperture, wall composition, and number of layers forming the wall, has a limited distribution within the Upper Jurassic to Upper Cretaceous. Even though the 
Leg 27 sections in which they occur are far from complete, several stratigraphically restricted and not overlapping faunal associations can be distinguished. From this it would appear that, once better known, Calcisphaerulidae will become similarly valuable for subdividing Jurassic and Cretaceous marine sediments as are other fossil groups already in use, such as foraminifera, calcareous nannoplankton, Radiolaria, and calpionellids.

\section{INCERTAE SEDIS FAMILY CALCISPHAERULIDAE}

Of the four family names proposed (Stomiosphaeridae and Cadosinidae by Wanner, 1940; Pithonellidae by Keller, 1946; and Calcisphaerulidae by Bonet, 1956) Calcisphaerulidae is used in this paper for the small Mesozoic, calcareous, single-chambered incertae sedis forms.

This family name is here given preference to others proposed because the name characterizes this fossil group well and because it has already been adopted by a number of authors.

Calcisphaerulidae were described from Jurassic and Cretaceous limestones. However, forms of apparently similar size and general morphology were also published from the Paleozoic by Williams (1880) and Derville (1931). Because the Paleozoic forms seem to have lived in different environments and because their relation to the Mesozoic forms is unknown, they are not further discussed or listed here.

Although reviews of Calcisphaerulidae studies have been given by a number of authors in recent years, the history of some early investigations needs further clarification, in order to explain the taxonomic principles followed in this paper. von der Mark (1858) was the first to figure objects that can most probably be regarded as Calcisphaerulidae (his pl. 1, fig. A1-A13). He did not, however, name these small forms $(80-160 \mu)$ which he described from the upper Senonian marls of Dolberg. Only later, in 1871, did von der Mark mention that similar but larger forms were described by Bronn as Orbulina universa. Obviously, there is no connection of von der Mark's Cretaceous forms with the middle Miocene to Recent Orbulina.

Spherical and elongate, single-chambered, calcareous Calcisphaerulidae of approximately $40-100 \mu$ size were published by Kaufmann in Heer (1865) under the names Lagena sphaerica and $L$. ovalis, from a polished section of the Senonian part of the Seewerkalk (Quarry at Seewen, Central Switzerland, type locality of the Seewerkalk).

Lorenz (1901) recognized that Kaufmann's species sphaerica and ovalis could not belong to the foraminiferal genus Lagena because of the presence, according to Lorenz, of two apertures instead of one in Lagena. He included them in his newly erected genus Pithonella, which he also placed in the foraminifera. Further, he maintained that the circular forms of Kaufmann's Lagena sphaerica are transverse sections through $L$. ovalis. However, because of a distinct size difference in transverse sections of $L$. ovalis and diameters of $L$. sphaerica, this assumption cannot be maintained. That both spherical and elongate Calcisphaerulidae exist in the Seewerkalk has now also been proven by SEM investigations on semiisolated specimens. Lorenz defined Pithonella as possessing two apertures, one at each end, and with widely variable wall thickness and grade of lateral inflation. $\mathrm{He}$ also distinguished two varieties-one slender, one inflated-without, however, formally naming them.

Thin sections from recently collected samples of Seewerkalk from the Seewen Quarry, Kaufman's type locality for Lagena sphaerica and L. ovalis, contain-similar to Lorenz' published Oberstdorf thin section-elongate and circular forms. The elongate specimens show none, one, or seemingly two apertures depending on the angle of section. None of the many semiisolated $L$. ovalis specimens from the same sample, which have so far been studied under the SEM, possess two apertures. It is therefore assumed that these second apertures as seen in thin-sectioned specimens do not exist, but may represent areas still covered by a thin calcite layer which is optically more transparent than the surrounding material. By slightly changing the depth of focus when viewing the thin sections, the aperture in question disappears or becomes less distinct, which supports the above assumption. However, before reaching a final conclusion, this problem has to be investigated further.

Whatever the outcome, the genus Pithonella, though originally described as possessing two apertures, has in fact only one, because Lorenz cites as its type Lagena ovalis Kaufmann. Kaufmann (in Heer, 1865) illustrates in his fig. 104 the drawing of a polished rock surface with numerous cross-sections of Lagena sphaerica and L. ovalis, some with, some without, single apertures, but none with two apertures. A single, more enlarged specimen of $L$. ovalis in longitudinal section and with one aperture is shown in his fig. 107a, an axial crosssection in 107b. Though not designated as such by Kaufmann, the specimen in fig. 107a, which also fits his description, must be regarded as the holotype of $L$. ovalis and consequently as the genotype of Lorenz' Pithonella.

Rhumbler, in 1906, erected the foraminiferal genus Orbulinaria for small spherical to ellipsoid tests with several apertures and with meander-like scaled surfaces. He did not, however, name a type species for this genus. Some years later, in 1909, Egger described a species Orbulinaria fallax based on material received by him from Rhumbler. Its locality is given as North Atlantic (should correctly read South Atlantic), near Ascension, from a depth of 240 meters, and is most probably of Recent to Sub-Recent origin. Egger did not recognize any apertures in the species examined by him. In the same publication he includes Kaufmann's Lagena sphaerica and $L$. ovalis in Orbulinaria and regards the one aperture shown by Kaufmann, and the two claimed by Lorenz, as the result of damage to the tests, and erroneously maintains that fully preserved specimens are without apertures. Neither Kaufmann's Lagena sphaerica and $L$. ovalis, both with single apertures, nor any other Cretaceous Calcisphaerulid can be included in Orhulinaria, whose type species is Egger's Orbulinaria fallax. 
The development in the erection of Calcisphaerulidae taxa after Egger, 1906, and published until 1972, is shown in Table 1, which contains, arranged in chronological order, the original taxa of family, genus, and species rank.

\section{SYSTEMATIC TREATMENT OF CALCISPHAERULIDAE-LM AND SEM INVESTIGATIONS}

\section{Introduction}

Similar to the calcareous nannoplankton, Calcisphaerulidae can be studied by two methods-light and scanning electron microscopy. The difficulties encountered, due to the strong difference in resolution, in comparing nannoplankton by the two methods are well known, and methods to overcome them have been published.

So far, Calcisphaerulidae have been described and figured in LM studies almost exclusively from thin sections. In a very few instances only (Bonet and Trejo, 1958; Bignot and Lezaud, 1964; Manivit, 1970), have isolated specimens been photographed under the LM. Because of their small size, the depth of focus is poor, and no distinct surface details become visible.

The only SEM views of isolated Calcisphaerulidae published so far are those by Banner (1972) and in the present paper. Surface features in considerable detail, which are not visible in thin sections are shown for the first time.

\section{Criteria Used For Establishing Genera and Species In Thin Sections}

Twelve different Calcisphaerulidae genera (see Table 1) have so far been proposed, all based on thin-sectioned specimens. Shape and arrangement of calcium carbonate crystals forming the test wall as seen in crosssections are used in most genera as distinguishing characters. The test shape is spherical for the majority of taxa. As seen in sections, the test has been described for several genera merely as being unilocular, for some as spherical, spherical to ovoid, in one as elongate.

Some taxa, however, possess distinctly different morphologies, one of them being a heart-shaped form originally described as Stomiosphaera conoides, for which Dufour, 1968, proposed the genus Bonetocardiella (of which Conejoconus Knauer, 1970, is a junior synonym).

Another taxon that deviates strongly from the spherical to moderately elongate test form is the slender (length $145-230 \mu$ width $35-45 \mu$ ), spindle-shaped (some specimens are bent, banana-like, possibly a different species) Pithonella trejoi, which has strongly pointed ends. In section, this species has a thick wall leaving a long, irregular-shaped narrow cavity. Because the overall morphology is so unique and so different from other Calcisphaerulidae, and because the stratigraphic distribution of these forms is apparently restricted (upper Albian to Cenomanian, ? Turonian), it is proposed to erect for such forms the new genus Andriella (named for E. Andri, Geological Institute, University of
Genova), with Pithonella trejoi Bonet, 1956, as type species.

Several other species that deviate considerably from the other Calcisphaerulidae in test shape or in strong variations in wall thickness within a specimen, have been proposed from thin sections under the following names:

Lagena diffringens de Lapparent: in thin sections an inflated triangle.

Cadosina ingens Vogler: with a distinct neck.

Stomiosphaera polygona Vogler: thick wall, inner surface circular, outer surface a seven-sided polygon.

Stomiosphaera acculeata Vogler: inner surface more or less circular, outer surface with some fine spines in equatorial area.

No mention was made of presence, absence, or shape of apertures in several of the genus descriptions. In some they are acknowledged as being present, in one as narrow, and in one (Calcisphaerula) expressly stated as "not existing." Random thin sections where apertures-in particular when small-are frequently missed must account largely for the insignificance previously attached to apertures in genus descriptions.

Species criteria, in addition to variability in generic criteria are: test size, thickness of wall, number of layers, and structural characteristics.

\section{Criteria for Determining Isolated Specimens by SEM}

Test features for describing isolated Calcisphaerulidae specimens by SEM are much more numerous and detailed compared with those seen in cross-sections under the LM. Size and shape of tests are more readily determined than in random thin sections. Presence, size, and shape of apertures are also easily seen while in thin sections they are missed in a high percentage of sections and, where present, the maximum size and shape is difficult to determine.

SEM investigations of isolated specimens have revealed that features of the inner and outer wall surface are of prime significance for distinguishing taxa. In the examined material of Leg 27, for instance, numerous forms can be distinguished not only by test shape and size, apertural characters, and number of layers forming the test, but, in particular, also by the ways in which the walls are formed. The different arrangements of the minute crystals of different size and shape are only very poorly seen in LM thin sections, but can be easily studied in broken specimens under the SEM.

The question arises as to whether the criteria used for generic distinction in LM cross-sections can also be adapted to isolated specimens investigated under the SEM.

The test shape of most Calcisphaerulidae genera proposed so far is spherical to moderately ovoid; in some it is distinctly elongate but still with rounded ends, in others different shapes have been observed as explained above.

From the Leg 27 specimens, it would appear that using wall structure, that is, crystal arrangement and number of layers to define taxa, as has been done by 
TABLE 1

Table of Mesozoic Calcisphaerulidae Families, Genera, and Species

\begin{tabular}{|c|c|c|c|c|}
\hline Year & Author & Family & Genus & Species \\
\hline 1865 & \multicolumn{2}{|l|}{ Kaufmann in Heer } & $\begin{array}{l}\text { Lagena* } \\
\text { Lagena }\end{array}$ & $\begin{array}{l}\text { sphaerica } \\
\text { ovalis }\end{array}$ \\
\hline 1901 & \multicolumn{2}{|l|}{ Lorenz } & Pithonella* & (ovalis) \\
\hline 1905 & \multicolumn{2}{|l|}{ Reinsch } & Palynosphaeren* & \\
\hline 1906 & \multicolumn{2}{|l|}{ Rhumbler } & Orbulinaria* & \\
\hline 1906 & \multicolumn{2}{|l|}{$\begin{array}{l}\text { Egger } \\
\text { de Lapparent }\end{array}$} & Orbulinaria & sphaerica \\
\hline \multirow[t]{2}{*}{1918} & de Lapparent & & $\begin{array}{l}\text { Lagena } \\
\text { Lagena }\end{array}$ & $\begin{array}{l}\text { orbulinaria } \\
\text { diffringens (not a } \\
\text { Calcisphaerulid) }\end{array}$ \\
\hline & & & Lagena & gracillima (Seguenza, 1862) \\
\hline 1924 & \multicolumn{2}{|l|}{ de Lapparent } & $\begin{array}{l}\text { Fibrosphaerae* } \\
\text { (not valid, see Durand- } \\
\text { Delga, 1957) }\end{array}$ & \\
\hline 1934 & \multicolumn{2}{|l|}{ Colom } & $\begin{array}{l}\text { Fibrosphaera } \\
\text { Fibrosphaera }\end{array}$ & $\begin{array}{l}\text { minutissima } \\
\text { stephanoides }\end{array}$ \\
\hline \multirow[t]{3}{*}{1940} & \multirow[t]{3}{*}{ Wanner } & Stomiosphaeridae* & Stomiosphaera* & moluccana \\
\hline & & Cadosinidae* & Cadosina* & fusca \\
\hline & & Cadosinidae & Cadosina & semiradiata \\
\hline \multirow[t]{10}{*}{1941} & \multirow[t]{10}{*}{ Vogler } & Cadosinidae & Cadosina & sublapidosa \\
\hline & & Cadosinidae & Cadosina & fusca misolensis \\
\hline & & Cadosinidae & Cadosina & radiata \\
\hline & & Cadosinidae & Cadosina & heliosphaera \\
\hline & & Cadosinidae & Cadosina & ingens \\
\hline & & Cadosinidae & Cadosina & misolensis \\
\hline & & Cadosinidae & Cadosinella* & gracillimoides \\
\hline & & Stomiosphaeridae & Stomiosphaera & polygona \\
\hline & & Stomiosphaeridae & Stomiosphaera & acculeata \\
\hline & & Stomiosphaeridae & Stomiosphaera & spinosa \\
\hline \multirow[t]{3}{*}{1946} & \multirow[t]{3}{*}{ Keller } & Pithonellidae & $\begin{array}{l}\text { Pithonella } \\
\text { Sphaerella* }\end{array}$ & caucasica \\
\hline & & & (name preoccupied, see & \\
\hline & & & $\begin{array}{l}\text { Voigt and Hantzschel, } \\
1964, \text { p. } 536 \text { ) }\end{array}$ & \\
\hline 1956 & Bonet & Calcisphaerulidae* & Calcisphaerula* & innominata \\
\hline & & Calcisphaerulidae & Stomiosphaera & similis \\
\hline & & Calcisphaerulidae & Stomiosphaera & conoidea \\
\hline & & Calcisphaerulidae & Pithonella & trejoi \\
\hline 1957 & Durand-Delga & & Stomiosphaera & colomi \\
\hline & & & Stomiosphaera & moreti \\
\hline 1958 & Colom and Allard & & Stomiosphaera & asdadensis \\
\hline 1959 & Leischner & & Stomiosphaera & alpina \\
\hline 1962 & Ayala and Seiglie & Calcisphaerulidae & Stomiosphaera & cardiiformis \\
\hline 1964 & Borza & & Stomiosphaera & carpathica \\
\hline & & & Stomiosphaera & malmica \\
\hline & & & Stomiosphaera & pulla \\
\hline 1966 & Nagy & & Cadosina & borzai \\
\hline & & & Cadosina & fibrata \\
\hline & & & Cadosina & tenuis \\
\hline & & & Cadosina & parvula \\
\hline 1966 & Azema & & Stomiosphaera & betica \\
\hline 1967 & Adams et al. & Calcisphaerulidae & Calcisphaerula & innominata lata \\
\hline 1968 & Dufour & Calcisphaerulidae & Bonetocaridella* & (cardiiformis) \\
\hline 1968 & Nowak & & Parastomiosphaera* & (malmica) \\
\hline & & & Carpistomiosphaera* & (borzai) \\
\hline & & & Carpistomiosphaera & tithonica \\
\hline & & & Colomisphaera * & (minutissima) \\
\hline & & & Colomisphaera & ornata \\
\hline & & & Colomisphaera & cieszynica \\
\hline & & & Hemiosphaera* & (parvula) \\
\hline & & & Stomiosphaera & echinata \\
\hline 1969 & Borza & Cadosinidae & Cadosina & nagy \\
\hline & & & Cadosina & pieniensis \\
\hline & & & Cadosina & vogleri \\
\hline & & & Cadosina & oraviensis \\
\hline & & & Cadosina & gigantea \\
\hline & & & Cadosina & sp. 1 \\
\hline & & & Cadosina & sp. 2 \\
\hline & & Stomiosphaeridae & Stomiosphaera & wanneri \\
\hline
\end{tabular}


TABLE 1 - Continued

\begin{tabular}{|c|c|c|c|c|}
\hline Year & Author & Family & Genus & Species \\
\hline 1969 & Colom & & $\begin{array}{l}\text { Globulinites* } \\
\text { (larger than other } \\
\text { Calcisphaerulidae) }\end{array}$ & tripartitus \\
\hline 1970 & Knauer & & $\begin{array}{l}\text { Conejoconus* } \\
\text { (junior synonym of } \\
\text { Bonetocardiella) }\end{array}$ & (conoideus) \\
\hline 1972 & Andri & $\begin{array}{l}\text { Calcisphaerulidae } \\
\text { Calcisphaerulidae }\end{array}$ & $\begin{array}{l}\text { Bonetocardiella } \\
\text { Pithonella }\end{array}$ & $\begin{array}{l}\text { conoidea var. extraflexa } \\
\text { perlonga }\end{array}$ \\
\hline 1972 & Borza & - & $\begin{array}{l}\text { Cadosina } \\
\text { Cadosina } \\
\text { Pithonella } \\
\text { Palynosphaera } \\
\text { (Reinsch, 1905) }\end{array}$ & $\begin{array}{l}\text { undosa } \\
\text { (spinosa) } \\
\text { multicava } \\
\text { brezovica }\end{array}$ \\
\hline
\end{tabular}

Note: Families, genera, and species are listed in chronological order. Asterisked family and genus names indicates first publication, species names in parenthesis indicate that taxon is used as type species for new of different genera, but was already published previously under a different generic name.

some authors whose taxa are based on thin sections, would lead to a large number of mainly monospecific genera. Therefore, differences in these features should be expressed on the species level. The same is true for apertures which are almost always present in isolated specimens, but may be absent in occasional specimens from each species.

Based on the foregoing, the test shape is considered the only suitable parameter for subdividing the family Calcisphaerulidae into genera and this practice is followed in this paper. By doing this, problems are largely avoided, at least on the generic level in comparing LM and SEM investigated specimens.

Because all intermediate shapes exist, forms ranging from spherical to distinctly elongate but still with rounded ends, are here placed in the genus Pithonella Lorenz 1901. The subsequently erected genera that contain forms of this shape but of varying wall structure and number of layers, as seen in thin sections, are, as explained above, placed in synonymy with Pithonella.

They are:

Stomiosphaera, Wanner 1940

Cadosina, Wanner 1940

Cadosinella, Vogler 1941

Calcisphaerula, Bonet 1956

Parastomiosphaera, Nowak 1968

Carpistomiosphaera, Nowak 1968

Colomiosphaera, Nowak 1968

Hemiosphaera, Nowak 1968

\section{MORPHOLOGICAL CHARACTERS OF PITHONELLA}

Test shape, number of layers, shape, size, and arrangement of crystals forming the layers, and apertural characters are here used to distinguish the 19 Pithonella species described as new and the four forms in open nomenclature. Variability in test size is limited in most species, but may be quite extreme in some.

The test shape varies from spherical to more or less ovoid to distinctly elongate with rounded to subrounded ends. Restrictions below the apertural area, resulting in a collar and a somewhat pointed distal end, were found in only one form, described in open nomenclature. Most species are restricted to one test shape: spherical, ovoid, or distinctly elongate; in some, however, the test may vary from spherical to ovoid or elongate.

The number of layers forming the test wall varies from one to three in the species described here. One- and two-layered forms are the most common. The thickness of individual layers is variable, it may range from approximately $1 \mu$ up to about $12 \mu$.

Each species includes forms with and without apertures. From this it may be assumed that the Calcisphaerulidae, and in particular the genus Pithonella as interpreted here, represent cysts of an as yet unknown organism, possibly algae. These cysts apparently have an early stage where they are closed and an aperture is formed in a later stage. This is demonstrated in the Leg 27 specimens where most specimens of a given species possess apertures, but some are usually present without.

Of particular interest in this respect is a specimen of Pithonella francadecimae (Plate 15, Figures 5,6) where the aperture is already formed, but with an operculum, that is that part of the test originally covering the apertural area, still loosely attached. In this species (Plate 14, Figures 10-12), as in others as, such as Pithonella sheilasantawae (Plate 14, Figure 4), the shape of the apertural edges have the appearance of having been "cut" out, somewhat like a pumpkin whose top has been cut. Other species again, like Pithonella gustafsoni, have quite smooth and rounded apertural edges.

The apertures of the species described here are as a rule circular, often somewhat irregular because of crystals of varying size forming the rim. The size of apertures is variable, some species such as Pithonella edgari (Plate 4, Figure 1; Plate 13, Figure 4) possess small apertures, others, as $P$. francadecimae (Plate 5, Figure 1; Plate 14, Figures 10-12) have apertures approaching test diameter. Considerable variability of aperture size may exist in certain species. An example is $P$. thayeri where in the studied material numerous specimens were also found to be without aperture (Plate 8, Figures 9-12; Plate 9, Figures 1-6).

Pithonella shows some similarity to Thoracosphaera in general test shape (spherical to slightly elongate) in having a more or less circular aperture and in having a test wall formed of individual crystals. However, the two genera differ considerably in size. Spherical Pithonella measure about $40-70 \mu$, whereas Thoracosphaera as 
measured from some figured specimens are approximately $7-24 \mu$. It could also not be determined from published SEM views of Thoracosphaera specimens (Haq und Lipps, 1971; Perch-Nielsen, 1972; Stradner, 1973) whether the test wall consists of a single layer, or, as is the case in some Pithonella species, of two or three layers. The stratigraphic distribution of the two genera is also different. Pithonella so far is known only from the Jurassic and Cretaceous, whereas Thoracosphaera is known chiefly from the Tertiary to Quaternary, but is also said (Bramlette and Martini, 1964) to occur in the uppermost Cretaceous (Maestrichtian). Possible relationships between Calcisphaerulidae (Pithonella) and Thoracosphaeridae (Thoracosphaera) are still to be investigated.

\section{METHODS OF STUDY}

With very few exceptions, published investigations on Calcisphaerulidae are all based on thin sections. Bonet and Trejo (1958) were the first to figure isolated Calcisphaerulidae specimens photographed under the light microscope. They figure Calcisphaerula innominata, Stomiosphaera sphaerica, St. conoides, Pithonella ovalis, and $P$. trejoi, all from ditch samples from Mexican boreholes. They became separated from the matrix by the fine fractioning of the sediment through bit action. This is the only published record of isolated Calcisphaerulidae from boreholes (ditch or core samples).

Bonet and Trejo give credit to Kaufmann (1865) and to Egger (1910) for having separated the first isolated Calcisphaerulidae. However, Kaufmann described his forms from a polished section of the very dense and hard Seewerkalk, and makes no mention himself of having studied isolated specimens. The specimens figured by Egger from material received by him from Rhumbler must be regarded as Recent to sub-Recent, hence, they have no relation to Cretaceous Calcisphaerulidae.

Bignot and Lézaud (1964) described a technique by which they isolated Pithonella specimens from sediments and photographed them under the light microscope. Manivit (1971) figured isolated Pithonella sphaerica (her pl. 30) and P. ovalis (herpl. 31). Because of the small size of the specimens and consequently restricted depth of focus, resolution in the photographs by Bonet and Trejo, Bignot and Lézaud, and Manivit is not sufficient to show any surface details.

Banner (1972) studied Calcisphaerulidae from early Cenomanian chalk of the Isle of Wight under the SEM. By this method, details of a distinctly reticulate/striate surface were published for the first time in specimens determined by Banner as Pithonella ovalis.

To check on the possible presence of Calcisphaerulidae in the Cretaceous clays and shales recovered from Leg 27 Sites 259, 260, 261, and 263, samples were washed onboard ship through a 325-mesh $(44 \mu)$ sieve, in addition to a routine check of the 230mesh $(63 \mu)$ fraction. As a result, numerous Calcisphaerulid specimens were recovered, most of which were retained on the 325-mesh sieve, some larger ones also on the 230 mesh.
For better and more rapid disintegration, the samples were treated with $\mathrm{H}_{2} \mathrm{O}_{2}$ prior to washing through a set of 80-, 230-, and 325-mesh sieves. After drying the fractions, the Calcisphaerulidae were separated from the residue by a fine water-wet brush and placed into foraminiferal assemblage slides (type Curtin) with a base of black photopaper inserted. On this, the specimens remain attached by water only and no glue is needed.

Test shape, aperture size, and more prominent features of surface morphology of the small specimens were sufficiently diverse to allow for a preliminary distinction of numerous types under the shipboard binocular microscope $(\times 80)$.

After termination of Leg 27, specimens of each "shipboard type" were examined under the SEM. By this method, many additional features became visible. Broken specimens revealed that each "shipboard type" not only possessed its distinct outside wall texture, but that in addition to one-layered forms, the walls of many types are composed of two, and in two cases, of three layers. Further, it was found that the textures of outer and inner surfaces of the test were always different.

Cross-sections and inner surfaces of test walls were made visible by placing specimens in a small hole in the photopaper base of the slide, covering them with a drop of water and carefully breaking them with a needle.

The specimens to be studied and photographed under the SEM were transferred from the slide to the stub by a fine, water-wet brush. Because of their minute size, natural adhesion of the specimens to the aluminum surface of the stub proved sufficient. Virtually none of the several hundred Leg 27 specimens prepared so far by this method for SEM investigation has been lost during handling or during the gold-coating process.

\section{Comparison of Isolated Leg 27 Pithonella Species with Species Described from Thin Sections}

Thin sections of Calcisphaerulidae do not reveal sufficient detail and resolution to allow for direct comparison with SEM views of isolated whole specimens, or broken tests showing the inside surfaces and cross-sections of the test wall.

To arrive at such a comparison, one has to either thinsection isolated specimens and view them under the LM, or to isolate or at least semiisolate topotypic material (as was successfully done in the dense Seewerkalk) and examine the specimens under the SEM. Polished and edged sections of limestone viewed under the SEM may eventually also prove to be of some use for comparison.

Apart from the difficulties in obtaining topotype material of published species, such methods are time consuming. The only attempt in comparing Leg 27 isolated specimens with published species in thin sections consisted of a preliminary SEM examination of some of Vogler's (1941) Misol Upper Jurassic-Lower Cretaceous samples. However, it was not possible to definitely correlate any of the Site 261 species, which are of approximately the same age, with those described by Vogler.

Some more general comparisons based on ranges and gross morphology indicate that few, if any, of the Leg 27 
isolated Pithonella species will eventually turn out to be synonyms with species described from thin sections. For this reason, and because of the belief that creating an occasional synonym instead of a homonym poses fewer taxonic problems, 19 of the 23 distinguished forms in the Leg 27 Late Jurassic to Late Cretaceous sediments are here described as new species. Open nomenclature is applied to four forms which so far were found only as single specimens.

\section{X-RAY POWDER DIAGRAMS TO DETERMINE CRYSTALS FORMING PITHONELLA TESTS}

Because of the small size and scarcity (except for Pithonella thayeri) of all species, the crystals forming tests of the here-described forms are best identified by $\mathrm{X}$-ray Gandolfi camera method. For this report two specimens of the two-layered Pithonella krasheninnikovi, one with the inner and outer layer intact (Plate 7, Figure 1; Plate 18, Figures 2, 11), and one with the outer layer removed (Plate 19, Figure 7; Plate 20, Figure 1), were investigated by means of a Gandolfi camera with $\mathrm{CuK}$ $\gamma$-rays and $\mathrm{Ni}$ filter. Exposure time for each film was 6 hours. The specimens were mounted on a glass thread and placed in the camera. The following lines were identified by their values on the film of Sample 1 (specimen with the outer layer removed and the larger inner layer crystals exposed):

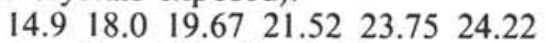

The $\theta$ values for calcite for $\mathrm{CuK} \gamma$-rays as taken from the literature (X-ray powder data for ore minerals. The Peacock Atlas, New York, 1962) are:

\section{$\begin{array}{llllll}14.65 & 17.9 & 19.65 & 21.55 & 23.65 & 24.25\end{array}$}

Sequence of intensities:

$$
1045576
$$

The film of Sample 2 (with the outer layer consisting of smaller crystals present) shows the same sequence of lines. Because of the smaller volumes of the individual outer layer crystals, the lines are weaker compared with those on the film of Sample 1. The strongest line at value 14.65 shows slight widening, an indication of calcite crystals small in size.

Pithonella thayeri which occurs in large numbers at Sample $261-33-1,0-20 \mathrm{~cm}$, was examined by the X-ray powder diagram Guinier camera with $\mathrm{CuK} \gamma$-rays. The crystals are calcite as in Pithonella krasheninnikovi. From the above X-ray results of Pithonella krasheninnikovi and P. thayeri, and from the fact that tests of the species described here quickly dissolve when placed in $10 \% \mathrm{HCl}$, it is concluded that they all are composed of calcite.

\section{OCCURRENCE AND AGE OF CALCISPHAERULIDAE IN LEG 27}

\section{SITES 259, 260, 261, 263, AND IN THE EAST} INDIAN ARCHIPELAGO

\section{Leg 27 Sites (Figure 1)}

The ages assigned to the Pithonella species described here are based on those indicated by concurring fossils, particularly on calcareous nannoplankton (see Proto Decima, this volume), benthonic foraminifera (see

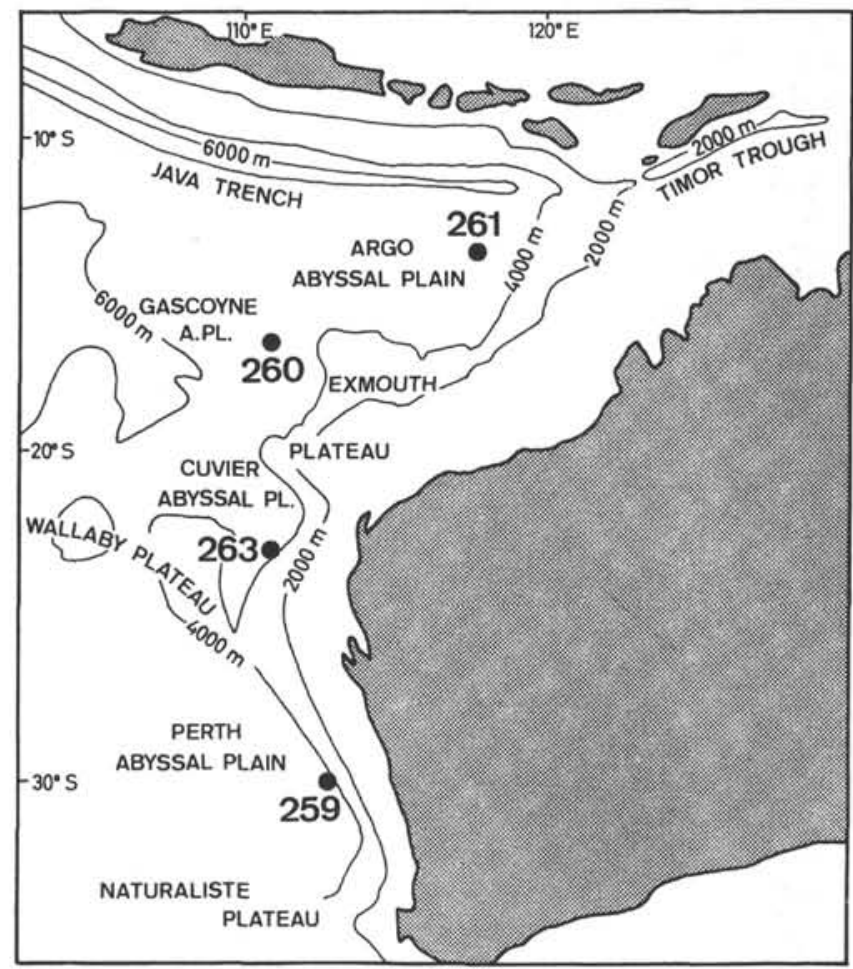

Figure 1. Location of Leg 27 sites 259, 260, 261, 263.

Scheibnerova, this volume), planktonic foraminifera (see Krasheninnikov, this volume), and at one site also on dinoflagellates (see Wiseman and Williams, this volume). As evident from Figures 2, 3, and 5, ages of given intervals may vary depending on the fossil group used. This is particularly true for Site 263. These

\begin{tabular}{|c|c|c|c|c|c|c|c|c|c|c|}
\hline \multicolumn{3}{|c|}{$\begin{array}{l}\text { Age based } \\
\text { on Leg } 27\end{array}$} & \multirow[b]{2}{*}{ Core } & \multirow[b]{2}{*}{ 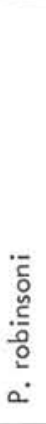 } & \multirow[b]{2}{*}{ 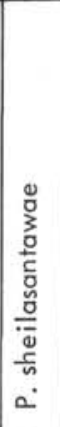 } & \multirow[b]{2}{*}{ 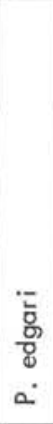 } & \multirow[b]{2}{*}{$\begin{array}{l}\frac{\bar{\lambda}}{\frac{2}{3}} \\
\therefore \\
0\end{array}$} & \multirow[b]{2}{*}{ 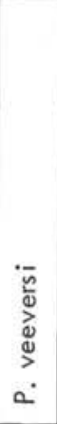 } & \multirow[b]{2}{*}{ 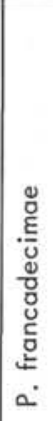 } & \multirow[b]{2}{*}{ 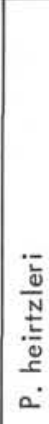 } \\
\hline 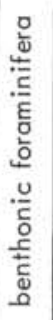 & 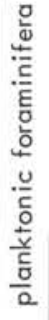 & 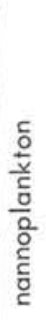 & & & & & & & & \\
\hline \multirow{7}{*}{$\begin{array}{l}\frac{c}{0} \\
\frac{0}{\alpha} \\
\frac{\alpha}{\alpha} \\
\frac{0}{2} \\
\frac{0}{2}\end{array}$} & \multirow{7}{*}{$\frac{\frac{5}{0}}{\frac{0}{\alpha}}$} & \multirow{7}{*}{ 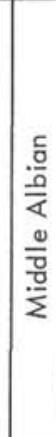 } & $12-2,60-62$ & & $x$ & $x$ & $x$ & & $x$ & $x$ \\
\hline & & & $13-2,60-62$ & & & $x$ & $x$ & $\mathrm{x}$ & $x$ & $\mathrm{x}$ \\
\hline & & & $14-3,135-137$ & $x$ & $\mathrm{x}$ & $x$ & $\mathrm{x}$ & $x$ & $\mathrm{x}$ & $x$ \\
\hline & & & $15-5,124-126$ & & $x$ & $x$ & $x$ & & & \\
\hline & & & $16-3,80-82$ & & $x$ & $\mathrm{x}$ & $x$ & & & \\
\hline & & & $17-2,47-49$ & $x$ & $x$ & $x$ & $x$ & & & \\
\hline & & & $17-3,38-40$ & $x$ & $x$ & $x$ & & & & \\
\hline
\end{tabular}

Figure 2. Distribution of Pithonella species in Site 259. 
differences, particularly for the Barremian-Albian interval, are due to an absence of good coordination of the stratigraphic distribution of the various fossil groups and lack of a close comparison of those fossils with corresponding faunas of the classical stages.

\section{Site 259 (Figure 2)}

In Cores 12-17, mostly brownish, zeolite-rich nanno clays, Calcisphaerulidae are frequent and occur with rich benthonic and planktonic foraminifera and calcareous nannoplankton. The age discrepancy indicated by these fossils is minor, only varying between middle and upper Albian. Also present are ostracoda, poorly preserved Radiolaria, and, in Core 14, molluscs.

\section{Site $\mathbf{2 6 0}$ (Figure 3)}

The only Upper Cretaceous Calcisphaerulidae of Leg 27 were found in brown clays of Core 6, where they occur with planktonic foraminifera, including species of Globotruncana indicating a Senonian age. The tests of the foraminifera and Pithonella species frequently show signs of dissolution, an indication that they were deposited below the lysocline. Radiolaria are rare and poorly preserved, calcareous nannoplankton are absent. The frequent fish debris present is another indication of the sediment having been exposed to calcium carbonate dissolution. The Pithonella species of Cores 9-15, in nanno ooze and clays, are middle Albian based on nannoplankton, Albian based on planktonic foraminifera, and ? upper Aptian to upper Albian based are associated with a rich planktonic and benthonic foraminiferal fauna, calcareous nannoplankton, some Radiolaria, ostracoda, and mollusca. Those of Cores 1215 occur with scarce arenaceous foraminifera and poor

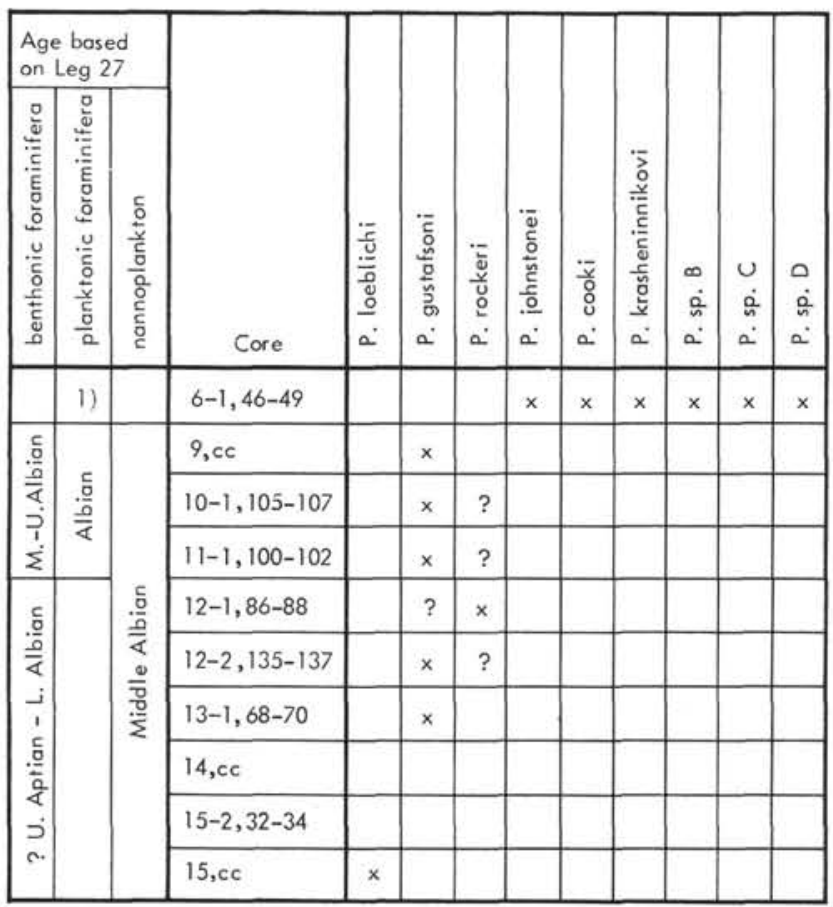

Figure 3. Distribution of Pithonella species in Site 260. calcareous nannoplankton. Poorly preserved Radiolaria are abundant in Cores 12 and 13, CC catcher, rare in Cores 14 and $15, \mathrm{CC}$.

\section{Site 261 (Figure 4)}

The Pithonella species of Cores 31, 32, 33, (semilithified, dark, reddish-brown claystone; Valanginian to upper Oxfordian), with $P$. thayeri occurring in floods, are dated by nannoplankton only. The benthonic, calcareous, and arenaceous foraminifera present are not diagnostic. The nannoplankton is used for dating these cores, where ostracoda are very sparse and Radiolaria absent. Dinoflagellates of Core 32 indicate Kimmeridgian/Tithonian, which is in good agreement with the nannoplankton dating.

\begin{tabular}{|c|c|c|c|c|}
\hline $\begin{array}{l}\text { Age based } \\
\text { on Leg } 27 \\
\text { nannoplankton }\end{array}$ & Core & 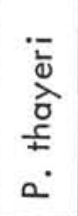 & 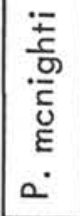 & 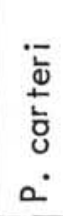 \\
\hline Tithonian & $31, c c$ & $x$ & $x$ & $x$ \\
\hline Kimmeridgian & $32, \mathrm{cc}$ & $x$ & & \\
\hline U. Oxfordian & $33-1,0-20$ & $x$ & & \\
\hline
\end{tabular}

Figure 4. Distribution of Pithonella species in Site 261.

\section{Site 263 (Figure 5)}

Based on nannoplankton (Eiffelithus turriseiffeli), the sparse Pithonella present in Sample 3, CC and Cores 5 and 17 are upper Albian, whereas benthonic foraminifera indicate for Core 17 an Aptian or older and for Cores 3, CC and 5 ?lower Albian. Dinoflagellates date the interval Core 3, CC-17 as Barremian to upper Aptian or lower Albian.

The Upper Cretaceous to Upper Jurassic penetrated in Leg 27 is stratigraphically incomplete. While the Albian in particular is well represented, most of the Upper Cretaceous (Cenomanian-Maestrichtian), with the exception of some Senonian, appears to be absent or could at least not be dated as such, based on the available fossil record. The deeper parts of the Lower Cretaceous (Hauterivian-Valanginian) could only be poorly dated by fossils; they are devoid of Calcisphaerulidae. Latest Jurassic, rich in Calcisphaerulidae, is present at Site 263.

Three main groups of Pithonella species, that is Upper Jurassic, Albian, and Senonian, each restricted in distribution, can be distinguished. This indicates that the species have reasonable short ranges, which, however, may be controlled to an as yet unknown extent by 


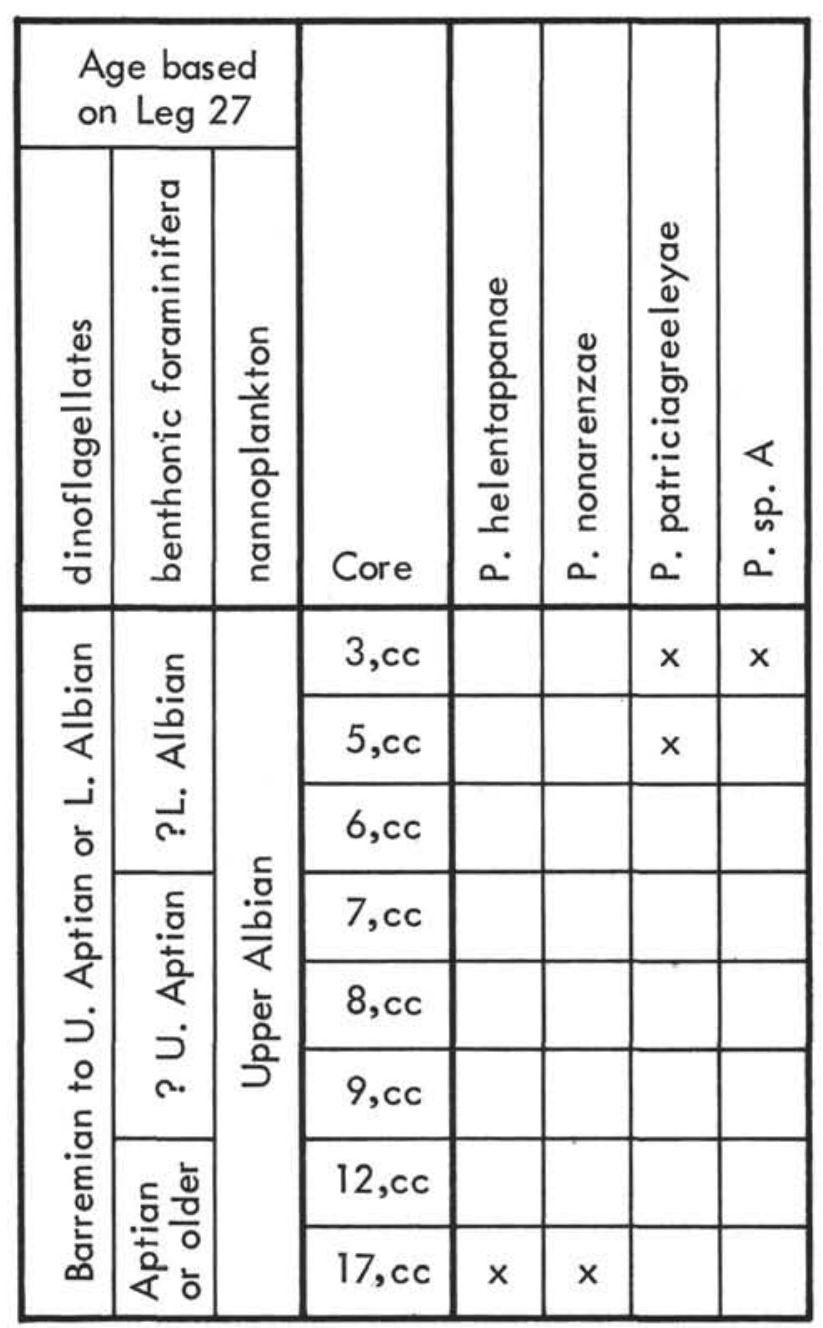

Figure 5. Distribution of Pithonella species in Site 263.

environment. From this it may be concluded that the Calcisphaerulidae when studied in isolated or semiisolated form with appropriate methods, including SEM, may be of more stratigraphic and ecologic significance than considered so far. Long ranges assigned to certain taxa in the literature should therefore be viewed with care, at least some of them may well be due for revision and be considerably shortened.

\section{East Indian Archipelago}

Calcisphaerulidae have a wide distribution in Jurassic and Cretaceous sediments of the East Indian Archipelago. Wanner (1940) described three species, Stomiosphaera moluccana, Cadosina fusca, and $C$. semiradiata, here all included in the genus Pithonella. He did not designate holotypes for his newly erected forms of which he gives figures from the following localities: $S$. moluccana from Central Ceram (his fig. 1-12); from Ofu, Timor (fig. 13-15); and from the Island of Fatjet, Misol (fig. 16-18). C. fusca from Ofu, Timor (fig. 19-29); and the Island of Fatjet (fig. 30); and C. semiradiata from Central Ceram (fig. 36) and Ofu (fig. 37).

The Central-Ceram specimen (fig. 36) of $C$. semiradiata differs from the Ofu specimen (fig. 37) in that the outer of the two layers of the test, which has a radial arrangement of calcite crystals, is only slightly thinner than the inner layer of irregularly arranged calcite, whereas in the Ofu specimen the outer radial layer measures only a third or less of the inner layer.

The specimens of the three species figured as coming from near the village of Ofu, Amanuban coastal range, Timor, are from a whitish, bedded limestone (Wanner sample 688). Based on Belemnopsis jonkeri and $B$. perlonga which were found nearby, Sample 688 is dated by Wanner as higher Malm, probably Kimmeridgian, or possible Tithonian. This compares well with the dating of the basal sediments at Site 261, which is about 1500 $\mathrm{km}$ from Timor.

Wanner (1940) cites the following occurrences of Calcisphaerulidae from the East Indian Archipelago, in addition to those mentioned above:

The Orbulinaria sphaerica in Brouwer (1919, p. 731) were determined by Wanner, based on the original sections, as Stomiosphaera moluccana and Cadosina semiradiata, with $C$. fusca absent. Wanner regards them as upper Malm or Lower Cretaceous.

The Orbulinaria found by Tan Sin Hok (1927, p. 140) in the Upper Jurassic Radiolaria-coccolith limestone of Batu Hun and Sua Lain on the Island of Rotti, are regarded by Wanner to include Stomiosphaera or Cadosina, or both.

Bothé (1927, p. 99) quotes Lagena orbulinaria and $L$. sphaerica from gray limestones on the Island of Button, southeast of Celebes. According to Bothé, the Calcisphaerulidae and Belemnites alfuriens-bearing limestones are overlain and underlain by beds with Globotruncana, that is Upper Cretaceous. The possibility thus exists that the Calcisphaerulidae are Upper Cretaceous, that is, of approximately the same age as the "Lagena" sphaerica originally described by Kaufmann (in Heer, 1865), or are older, in which case their position between Upper Cretaceous layers is the result of tectonic movements. Finally, Wanner considers the fossils figured in a thin section by Loczy (1934, pl. 2, fig. 3) from Celebes to be Stomiosphaera moluccana.

Vogler (1941) described in his publication on the Upper Jurassic and Lower Cretaceous of Misol (Dutch East Indies), the following Calcisphaerulidae species (age ranges given as by Vogler):

Cadosina fusca Wanner upper Oxfordian \pm Neocomian

Cadosina semiradiata Wanner \pm upper Malm

Cadosina sublapidosa Vogler \pm Neocomian

Cadosina lapidosa Vogler \pm Neocomian

Cadosina fusca misolensis Vogler upper Malm - \pm Neocomian

Cadosina radiata Vogler \pm Neocomian Cadosina helicosphaera Vogler \pm Neocomian Cadosina misolensis Vogler \pm upper Malm \pm Neocomian

Cadosina ingens Vogler \pm Neocomian Upper Cretaceous

Cadosina gracillima (Seguenza) Cenomanian Maestrichtian

Pithonella ovalis (Kaufmann) Cenomanian Maestrichtian 
Cadosinella gracillimoides Vogler Cenomanian Maestrichtian

Stomiosphaera moluccana Wanner upper Oxfordian, \pm Malm, \pm Neocomian

Stomiosphaera cf. orbulinaria (de Lapparent)

Cenomanian-Maestrichtian

Stomiosphaera $\mathrm{cf}$. diffringens (de Lapparent)

Cenomanian-Maestrichtian

Stomiosphaera polygona Vogler \pm Neocomian

Stomiosphaera acculeata Vogler \pm Malm, \pm Neocomian

Stomiosphaera spinosa Vogler \pm Neocomian, Aptian, and Albian

Of these, C. ingens, St. polygona, St. acculeata, St. cf. diffringens, and St. spinosa are not regarded here as belonging to the Calcisphaerulidae. Their tests are either angular, possess regularly or irregularly arranged distinct spines, have a distinct neck, or are irregular in outline.

Of the remaining forms, one group is, according to Vogler, restricted to the Upper Jurassic to Lower Cretaceous (Neocomian); a second one to the Upper Cretaceous (Cenomanian to Maestrichtian).

Of the published East Indian Archipelago species, the three of Wanner (1940) and nine of Vogler fall in the Oxfordian to Neocomian, and thus are of about the same age as Pithonella carteri, $P$. mcnighti, and $P$. thayeri of Leg 27. The five species of Vogler whose range is given as Cenomanian to Maestrichtian may compare in age with Pithonella krasheninnikovi, $P$. cooki, $P$. johnstonei, P. sp. B. P. sp. C, and P. sp. D of Leg 27 (Senonian). No Calcisphaerulidae have been described by these authors from the Aptian/Albian (except for St. spinosa, which is here not regarded as a Calcisphaerulid). Thus, there are no described forms from the East Indian Archipelago to compare with the Leg 27 Aptian-Albian species described here as new.

\section{PRELIMINARY COMPARISON OF LEG 26 AND LEG 27 CALCISPHAERULIDAE}

No special effort was made onboard ship during Leg 26 to obtain and study Calcisphaerulidae. Samples were not washed through the $44 \mu$ sieve where most Calcisphaerulidae examined in the Leg 27 samples were retained. However, a preliminary check of some Leg 26, Site 257 Albian samples, washed through the $63 \mu$ sieve and made available by René Herb, Leg 26 paleontologist, showed the presence of large specimens of Pithonella.

Specimens of Sample 26-257-7, CC were examined by SEM which was found to contain numerous Pithonella francadecimae and also specimens of $P$. heirtzleri and $P$. robinsoni. With Hedbergella planispira, Ticinella aff. princela and Prediscosphaera cretacea, this core is dated as middle Albian, Prediscosphaera cretacea Zone.

At Site 259 of Leg 27, Pithonella francadecimae and $P$. heirtzleri occur in Cores 12-14, P. robinsoni in Cores 14 and 17 , the whole interval also being dated on nannoplankton evidence as middle Albian, Prediscosphaera cretacea Zone. Furthermore, the planktonic foraminifera species present in these intervals at Sites 257 and 259 are comparable.
Cores $12-17$ at Site 259 contain a number of additional Pithonella species to those listed above (see Figure 2), which were not seen in the $63 \mu$ fraction of Sample 7, CC at Site 257. This may be explained by the fact that only the largest specimens, which represent a small portion of the total number of Pithonella specimens, were retained in that mesh. To obtain a more complete Pithonella association in this and other Leg 26 cores, samples would have to be washed through the $44 \mu$ sieve.

\section{SYSTEMATIC DESCRIPTION}

\section{Family Calcisphaerulidae Bonet 1956} Genus PITHONELLA Lorenz 1901

Single-chambered tests; spherical to ovoid, to distinctly elongate with rounded ends. Diameter of spherical tests approximately $40-70 \mu$ maximal length of elongate forms up to $120 \mu$ or slightly more. Wall consisting of calcite crystals of varying size, shape, and arrangement. They may form one, two, or three distinct layers. In multilayered forms, thickness of individual layers, and crystal size, shape, and arrangement may or may not be different in each layer. Thickness of individual layers may vary between about 1 and $12 \mu$, total wall thickneșs between about 4 and $12 \mu$.

A more or less circular aperture, variable in size, is usually present in elongate forms situated at one end. Occasional specimens may be without aperture. It is assumed that Pithonella tests represent a cyst stage of an as yet unknown organism, possibly a planktonic algae.

Known stratigraphic distribution: Jurassic, predominantly upper; Lower and Upper Cretaceous.

Pithonella carteri Bolli, n. sp.

(Plate 1, Figures 1-4; Plate 8, Figures 1-3; Plate 21, Figure 1)

Description of species: Test spherical, consisting a single layer of $4 \mu$ diameter. Calcite crystals forming test wall are small, fairly regular in size, thin, elongate, and irregularly interlocked. Inner and outer surfaces are similar (Plate 1, Figures 2-4). No distinct crystal faces become visible under the magnification used for this study.

Aperture, when present, variable in size, subcircular to irregular in circumference (Plate 1, Figure 1; Plate 8, Figure 2).

Dimensions of holotype: Diameter 47, aperture $13 \mu$.

Locality of figured specimens: Sample 27-261-31, CC. Northeastern Argo Abyssal Plain, about $200 \mathrm{~km}$ from foot of Scott Plateau, Indian Ocean, $12^{\circ} 57^{\prime} \mathrm{S}, 117^{\circ} 54^{\prime} \mathrm{E}$. Water depth 5687 meters, depth below sea floor 513 meters.

Age/range of species: Upper Jurassic, Tithonian (based on calcareous nannoplankton).

Lithology of type sample: Moderate reddish-brown, semilithified claystone.

Name: The species is named for Allen Carter, DSDP Leg 27 sedimentologist; University of New South Wales, Kensington, N.S.W., Australia.

Pithonella menighti Bolli, n. sp.

(Plate 1, Figures 5-8; Plate 8, Figures 4-8; Plate 21, Figure 2)

Description of species: Test spherical to very slightly irregular, formed by single layer of approximately $6 \mu$ thickness, consisting of fairly large, angular crystals. Their arrangement on outer surface fairly loose and irregular (Plate I, Figure 6; Plate 8, Figure 1). Large faces of generally plate-shaped crystals perpendicular to surface (Plate 1, Figure 8). Compared with outer surface, crystal ends on inner surface distinctly smaller, less elongate and of a somewhat granular aspect.

Aperture small (holotype), to moderate in size, and circular despite large crystals forming its rim (Plate 1, Figure 5; Plate 8, Figure 7).

Dimensions of holotype: Diameter test 52, aperture $15 \mu$.

Locality of figured specimens: Sample 27-261-31, CC. Northeastern Argo Abyssal Plain, about $200 \mathrm{~km}$ from foot of Scott Plateau, Indian Ocean, $12^{\circ} 57^{\prime} \mathrm{S}, 117^{\circ} 54^{\prime} \mathrm{E}$. Water depth 5687 meters, depth below sea floor 513 meters.

Age/range of species: Upper Jurassic, Tithonian (based on calcareous nannoplankton). 
Lithology of type sample: Moderate reddish-brown, semilithified claystone.

Name: The species is named for Brian K. McKnight, DSDP Leg 27 sedimentologist; Wisconsin State University, Oshkosh, Wisconsin.

Pithonella thayeri Bolli, n. sp.

(Plate 1, Figures 9-12; Plate 8, Figures 9-12; Plate 9, Figures 1-12; Plate 21, Figure 3)

Description of species: Test spherical to fairly irregular in shape, usually consisting of one layer of mainly very large crystals, up to $12 \mu$ in diameter. On outer surface crystals are of irregular shape and size, giving test a very rugged morphology. Crystal shape may vary from subrounded to irregular to angular with only occasional welldeveloped crystal faces. Appearance of test is that of an agglutinated form. Thickness of layer approximately $7-12 \mu$ equal size of larger crystals. Inner surface much smoother, in that spaces between large crystals are filled by small, regularly arranged crystals with welldeveloped faces. Inner surface thus regular with the exception that ends of some of the larger crystals forming test wall are still piercing through the layer of small crystals (Plate 1, Figures 11, 12; Plate 9, Figure 7). Small crystals on inner surface may in some specimens form an independent second inner layer (Plate 9, Figures 8, 9).

The species occurs in floods in samples from Samples 261-31, CC, 32 , CC, and $33-1,0-20 \mathrm{~cm}$. Often two specimens are attached to each other, apparently aperture against aperture (Plate 9, Figures 10-12). This may represent a reproductive stage.

Aperture irregular in size and shape though mostly circular to subcircular. Many of the examined specimens are without aperture.

Dimensions of holotype: Diameter 58, aperture $20 \mu$.

Locality of figured specimens: Sample 27-261-31, CC (holotype). See explanations Plates 8 and 9 for paratypes. Northeastern Argo Abyssal Plain, about $200 \mathrm{~km}$ from foot of Scott Plateau, Indian Ocean, $12^{\circ} 57^{\prime} \mathrm{S}, 117^{\circ} 54^{\prime} \mathrm{E}$. Water depth 5687 meters, depth below sea floor 513 meters.

Age/range of species: Upper Jurassic, upper Oxfordian-Tithonian (based on calcareous nannoplankton). Age of holotype: Tithonian.

Lithology of type sample: Moderate, reddish-brown, semilithified claystone.

Name: The species is named for Paul A. Thayer, DSDP Leg 27 sedimentologist; University of North Carolina, Wilmington, North Carolina.

Pithonella nonarenzae Bolli, n. sp.

(Plate 2, Figures 5-8; Plate 10, Figures 9-12; Plate 21, Figure 5)

Description of species: Test spherical to slightly elongate to slightly irregular ovoid, consisting of one layer of about $4 \mu$ thickness. The outer surface consists of small, $1-2 \mu$ fairly regular and tightly arranged calcite crystals. Many crystal faces are well developed (Plate 2, Figure 6) but the surface remains fairly smooth to finally granular (Plate 10, Figures 9-11). In cores-section the elongate crystals appear with their long axis in more or less radial position (Plate 2, Figure 8). The inner surface is similar to the outer but smoother. Crystal faces are not recognizable. Present, however, are small, fairly regularly arranged interspaces (Plate 2, Figures 7, 8; Plate 10, Figure 12). Aperture more or less circular, fiarly large (Plate 2, Figure 5; Plate 10, Figure 10) may also be absent (Plate 10, Figures 9, 11).

Dimensions of holotype: Diameter 54 , aperture $23 \mu$.

Locality of figured specimens: Sample 27-263-17, CC. Eastern edge of Cuvier Abyssal Plain, Indian Ocean, $23^{\circ} 20^{\prime} \mathrm{S}, 110^{\circ} 58^{\prime} \mathrm{E}$. Water depth 5065 meters, depth below sea bottom 394.5 meters.

Age/range of species: Upper Albian (based on calcafeous nannoplankton), Aptian or older (based on benthonic foraminifera), Barremian to upper Aptian or Lower Albian (based on dinoflagellates).

Lithology of type sample: Black, semilithified clay.

Name: The species is named for Nona Killmar Renz, DSDP Leg 27 paleontologist; University of California, Los Angeles.

Pithonella helentappanae Bolli, n. sp.

(Plate 2, Figures 1-4; Plate 10, Figures 1-8; Plate 21, Figures 4)

Description of species: Test spherical to very slightly elongate consisting of three layers, an outer compact one of 5-6 $\mu$ thickness, a middle layer of loosely arranged crystals, $5 \mu$ and a very thin third layer of $1-2 \mu$, giving the inner surface a smooth appearance.

Depending on its preservation, outer layer consists of moderately to distinctly angular well-developed calcite crystals as in Plate 10, Figures
7 and 8 . In some specimens, crystals may be corroded showing signs of secondary overgrowth, the spaces between crystals then being filled with micritic particles (Plate 10, Figure 2). Inner surface of outer layer smooth (Plate 2, Figure 4). The middle layer consists of oblong, welldeveloped, angular, pillar-like crystals with wide empty interspaces between individual crystals. With their long axis, crystals are radial to oblique in position (Plate 2, Figure 4). Thickness of middle layer has tendency to become reduced towards apertural area (Plate 10, Figures 4-6). The third, innermost thin layer, is constant in thickness and consists of small,compactly arranged crystals with their faces poorly recognizable. Some are slightly protruding from the inner surface (Plate 2, Figures 3 and 4; Plate 10, Figure 6).

A perture variable in size, circular. Some specimens without aperture (Plate 10, Figure 7), others with a very small aperture (Plate 10, Figure 3). Specimens with quite large and somewhat irregular apertures are also observed (Plate 2, Figure 1; Plate 10, Figures 4, 5).

Dimensions of holotype: Diameter 60 , aperture $30 \mu$.

Locality of figured specimens: Sample 27-263-17, CC. Eastern edge of Cuvier Abyssal Plain, Indian Ocean, $23^{\circ} 20^{\prime} \mathrm{S}, 110^{\circ} 58^{\prime} \mathrm{E}$. Water depth 5065 meters, depth below sea bottom 394.5 meters.

Age/range of species: Upper Albian (based on calcareous nannoplankton), Aptian or older (based on benthonic foraminifera), Barremian to upper Aptian or lower Albian (based on dinoflagellates).

Lithology of type sample: Black, semilithified clay.

Name: The species is named for Helen Loeblich Tappan, University of California, Los Angeles.

Pithonella patriciagreeleyae Bolli, n. sp.

(Plate 2, Figures 9-12; Plate 11, Figures 1-8; Plate 21, Figure 5)

Description of species: Test spherical, formed by one layer of about $4 \mu$ thickness. Surface mostly smooth, characterized by generally poorly delineated crystal faces. In some specimens, no crystal faces visible at all (Plate 11, Figures 1, 2); in others, surface appears pitted, possibly a result of solution (Plate 11, Figures 3,4 ). A specimen where crystals are recognizable is figured on Plate 11, Figures 5, 6. In section, long axis of crystals may be in one of two directions, resulting in a cross-arrangement of individual crystals (Plate 2, Figure 12). Small faces of crystal ends are better preserved on inner surface (Plate 2, Figure 12). Plate 2, Figure 11 shows existence on inner surface of numerous small, open spaces between crystal ends.

Some specimens without aperture, some with large ones, somewhat irregularly shaped but always nearly circular. Apertural rim rough, determined by crystal faces in cross position.

Dimensions of holotype: Diameter 57, aperture $25 \mu$.

Locality of figured specimens: Sample 27-263-3, CC, basal part. (holotype). See explanations Plate 11 for paratypes. Eastern edge of Cuvier Abyssal Plain, Indian Ocean, $23^{\circ} 20^{\prime} \mathrm{S}, 110^{\circ} 58^{\prime} \mathrm{E}$. Water depth 5065 meters, depth below sea bottom 100 meters.

Age/range of species: Reworked in Tertiary, together with the following Lower Cretaceous fossils: upper Albian (based on calcareous nannoplankton), ? lower Albian (based on benthonic foraminifera), Barremian to upper Aptian or lower Albian (based on dinoflagellates).

Lithology of type sample: Black, clayey nanno ooze.

Name: The species is named for Patricia Paluso Greeley, DSDP Leg 27 paleontological technician; DSDP, Scripps Institution of Oceanography, La Jolla, California.

Pithonella loeblichi Bolli, n. sp.

(Plate 3, Figures 1-4; Plate 11, Figures 9-12; Plate 12, Figures 1-3; Plate 22, Figure 1)

Description of species: Test spherical, with two layers: a thick outer one of $6-8 \mu$ and a very thin inner one of about $1 \mu$ thickness. Outer

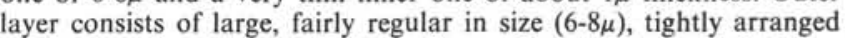
calcite crystals with well-developed faces (Plate 3, Figures 1, 2). Inner layer consists of very small, closely packed, regularly sized (about $1 \mu$ ) and well-developed crystals giving inner surface a granular aspect (Plate 3, Figure 3). Inner layer rather loosely attached to ends of large crystals of outer layer (Plate 3, Figure 4; Plate 12, Figure 3).

Aperture fairly large, circular, its rim determined by large crystals of outer layer (Plate 12, Figure 2).

Dimensions of holotype: Diameter 58 , aperture $25 \mu$.

Locality of figured specimens: Sample 27-260-15, CC. Gascoyne Abyssal Plain, at foot of Exmouth Plateau, Indian Ocean, $16^{\circ} 09^{\prime} \mathrm{S}$, 
$110^{\circ} 18^{\prime}$ E. Water depth 5709 meters, depth below sea floor 300.5 meters.

Age/range of species: Middle Albian (based on calcareous nannoplankton), ? upper Aptian to lower Albian (based on benthonic foraminifera).

Lithology of type sample: Medium bluish-gray, nanno ooze.

Name: The species is named for Alfred R. Loeblich, Jr.; University of California, Los Angeles.

Pithonella rockeri Bolli, n. sp.

(Plate 3, Figures 5-8; Plate 12, Figures 4-6; Plate 22, Figure 2)

Description of species: Test spherical consisting of one layer. Outer surface predominantly formed by small subangular calcite crystals, 1$3 \mu$. Crystals tightly interlocked but with distinct boundaries. Characteristic for species is presence of occasional much larger, up to $12 \mu$, subrounded crystals, somewhat irregularly distributed over test surface (Plate 3, Figure 6; Plate 12, Figures 4,5). Only few of the small crystals forming outer surface are visible on inner surface. Most of the inner surface consists of numerous very small (about $1 \mu$ ), regularly arranged crystals, apparently filling interspaces of larger crystals. These fine crystals, forming the inner surface, may be interpreted as a second layer, although no distinct boundary exists between the outer and inner layers (Plate 3, Figures 7, 8).

Aperture large in holotype, circular, but somewhat irregular, as a result of varying sizes of crystals forming its rim. Some specimens (Plate 12, Figure 4) may be without aperture.

Dimensions of holotype: Diameter 54, aperture $27 \mu$.

Locality of figured specimens: Sample 27-260-12-1, 86-88 cm. Gascoyne Abyssal Plain, at foot of Exmouth Plateau, Indian Ocean, $16^{\circ} 09^{\prime} \mathrm{S}, 110^{\circ} 18^{\prime} \mathrm{E}$. Water depth 5709 meters, depth below sea floor 263.5 meters.

Age/range of species: Middle Albian (based on calcareous nannoplankton), ?upper Aptian-lower Albian (based on benthonic foraminifera).

Lithology of type sample: Orange-pink to dark yellowish-brown, nanno ooze.

Name: The species is named for Karl Rocker, DSDP Leg 27 physicist; Naval Civil Engineering Laboratory, Port Hueneme, California.

Pithonella gustafsoni Bolli, n. sp.

(Plate 3, Figures 9-12; Plate 12, Figures 7-12; Plate 13, Figures 1, 2; Plate 22, Figure 3)

Description of species: Test spherical, formed by one layer of about $4 \mu$ thickness. Outer surface consists of subrounded to angular fairly regular in size calcite crystals of $1-2 \mu$, arranged in tight, cobblestonelike pattern (Plate 3, Figure 10). Crystals elongate in cross-section, slightly conical with long axis in radial position. Wall thickness equals length of crystals (Plate 3, Figure 12; Plate 13, Figures 1, 2). Inner surface similar to outer, but crystal ends more angular, slightly smaller and with faces better developed (Plate 3, Figure 11; Plate 13, Figure 2). Circular aperture fairly small, regular (Plate 3, Figure 9; Plate 12, Figure 9). Plate 12, Figures 7, 8, and 12 shows specimens where apertures are enlarged because part of rim is broken out.

Dimensions of holotype: Diameter 50, aperture $14 \mu$.

Locality of figured specimens: Sample 27-260-9, CC (holotype). See explanations Plates 3, 12, and 13 for paratypes. Gascoyne Abyssal Plain, at foot of Exmouth Plateau, Indian Ocean, $16^{\circ} 09^{\prime} \mathrm{S}, 110^{\circ} 18^{\prime} \mathrm{E}$. Water depth 5709 meters, depth below sea floor 243.5 meters.

Age/range of species: Middle Albian (based on calcareous nannoplankton). ?upper Aptian-lower (Site 260, Cores 12-18), middleupper Albian (Site 260, Cores 9, CC to 11) (based on benthonic foraminifera).

Lithology of type sample: Stiff, dark yellowish-brown nanno ooze.

Name: The species is named for Ted B. Gustafson, DSDP Leg 27 Laboratory Officer; DSDP, Scripps Institution of Oceanography, La Jolla, California.

\section{Pithonella edgari Bolli, n. sp.}

(Plate 4, Figures 1-4; Plate 13, Figures 3-7; Plate 22, Figure 4)

Description of species: Test spherical to slightly elongate, consisting of two layers of calcite crystals, an outer one of about $5 \mu$ thickness, and an inner one of about $2 \mu$ thickness. Outer layer with distinctly angular, well-developed, fairly loosely arranged crystals with distinct interspaces. Crystals plate-shaped with large faces perpendicular to surface. Faces forming surface may be covered by small subhedral pustules (Plate 4, Figure 2).

Crystals of inner layer of apparently similar shape and arrangement as those of outer layer. They are, however, smaller and more tightly packed. Inner surface fairly smooth, compact but still with some interspaces between crystals (Plate 4, Figure 3 ).

Aperture circular, small to moderate in size. Rim formed by angular, fairly large crystals of outer layer and, therefore, somewhat irregular.

Dimensions of holotype: Diameter 50, aperture $14 \mu$.

Locality of figured specimens: Sample 27-259-15-5, 124-126 cm (holotype). See explanations Plates 4 and 13 for paratypes. Eastern side of Perth Abyssal Plain, at foot of continental slope, Indian Ocean, $29^{\circ} 37^{\prime} \mathrm{S}, 112^{\circ} 42^{\prime} \mathrm{E}$. Water depth 4712 meters, depth below sea floor 139 meters.

Age/range of species: Middle Albian (based on calcareous nannoplankton), Albian (based on planktonic foraminifera), upper Albian (based on benthonic foraminifera).

Lithology of type sample: Olive-gray to greenish-gray, zeolite-rich nanno ooze.

Name: The species is named for N. Terence Edgar, DSDP chief scientist; DSDP, Scripps Institution of Oceanography, La Jolla, California.

Pithonella robinsoni Bolli, $n$. sp.

(Plate 4, Figures 5-8; Plate 13, Figures 8-12; Plate 14, Figures 1-3; Plate 22, Figure 5)

Description of species: Test slightly to fairly distinctly elongate with two layers of calcite crystals, almost equal in thickness, each measuring about $4-5 \mu$. Outer layer consists of two different crystal types, one distinctly larger than the other. The large crystals, measuring up to $8 \mu$, much less frequent, angular to subrounded and fairly irregularly distributed over surface, except for apertural and posterior ends where they may be more frequent (Plate 13, Figures 8 , $11,12)$. Second type of crystals much smaller, up to $2 \mu$, angular to subangular, filling in spaces between large crystals (Plate 4, Figure 10). Inner layer with compactly arranged crystals, on its outer side of a cobblestone pattern, though fairly smooth (Plate 14, Figure 3 ). Inner surface with compactly arranged, well-developed crystal ends of about $1-3 \mu$ size (Plate 4 , Figure 7)

Adhesion between outer and inner layers only slight because crystals of smooth outer surface of inner layer are not interlocking with the more loosely arranged crystals of different sizes of outer layer (Plate 14, Figures 2, 3).

Aperture circular, small to moderate in size. Rim irregular, determined by the large crystals of outer layer.

Dimensions of holotype: Length 58 , width 52 , aperture $15 \mu$.

Locality of figured specimens: Sample 27-259-17-2, 47-49 cm (holotype). See explanations Plates 4,13 , and 14 for paratypes. Eastern side of Perth Abyssal Plain, at foot of continental slope, Indian Ocean, $29^{\circ} 37^{\prime} \mathrm{S}, 112^{\circ} 42^{\prime} \mathrm{E}$. Water depth 4712 meters, depth below sea floor 152.5 meters.

Age/range of species: Middle Albian (based on calcareous nannoplankton), Albian (based on planktonic foraminifera), upper Albian (based on benthonic foraminifera).

Lithology of type sample: Yellowish-brown, zeolite- and clay-rich nanno ooze.

Name: The species is named for Paul T. Robinson, DSDP Leg 27 sedimentologist; University of California, Riverside, California.

Pithonella sheilasantawae Bolli, n. sp.

(Plate 4, Figures 9-12; Plate 14, Figures 4-9; Plate 22, Figure 6)

Description of species: Test spherical to slightly ovoid, with two layers of calcite crystals, an outer one about $4 \mu$ thick and an inner much thinner one approximately $1 \mu$ thick.

Outer layer consists of irregular-shaped, angular crystals varying in size, up to $6 \mu$. In some specimens, crystal surfaces may be more or less corroded, resulting in their edges being subangular to slightly rounded. Small open spaces may exist between crystals (Plate 14, Figure 6). Generally, the larger crystals are arranged with the longer axis in radial position. Inner layer with small, tightly packed subrounded to rounded crystals of about $1 \mu$ (Plate 14, Figure 7). No distinct crystal faces or crystal orientation observed. 
Contact between the two layers fairly loose because of marked difference in crystal size, shape, and arrangement. Thickness of inner layer tends to become slightly reduced towards apertural area (Plate 14, Figures 4, 9). Aperture large, circular. Both layers and arrangement of crystals well visible in apertural rim (Plate 14, Figure 4), which is somewhat irregular, in that it is formed by individual crystal faces.

Dimensions of holotype: Diameter 58, aperture $28 \mu$.

Locality of figured specimens: Sample $27-259-17-3,38-40 \mathrm{~cm}$ (holotype). See explanations Plates 4 and 14 for paratypes. Eastern side of Perth Abyssal Plain, at foot of continental slope, Indian Ocean, $29^{\circ} 37^{\prime} \mathrm{S}, 112^{\circ} 42^{\prime} \mathrm{E}$. Water depth 4712 meters, depth below sea floor 154 meters.

Age/range of species: Middle Albian (based on calcareous nannoplankton), Albian (based on planktonic foraminifera), upper Albian (based on benthonic foraminifera).

Lithology of type sample: Yellowish-brown, zeolite- and clay-rich nanno ooze.

Name: The species is named for Sheila Santaw, DSDP Leg 27 Yeoman; DSDP Scripps Institution of Oceanography, La Jolla, California.

Pithonella francadecimae Bolli, n. sp.

(Plate 5, Figures 1-4; Plate 14, Figures 10-12; Plate 15, Figures 1-6; Plate 23, Figure 1)

Description of species: Test spherical to slightly elongate, consisting of two layers, an outer one $4 \mu$ thick, an inner one $3 \mu$ thick. Irregularly shaped and distributed pores present on both outer and inner layer (Plate 5, Figures 1-4; Plate 14, Figures 10-12; Plate 15, Figures 2, 4). Surface of outer layer smooth, shiny under light microscope. Crystals irregular in shape and size, tightly interlocked, crystal boundaries visible only under high magnification (Plate 5, Figure 2; Plate 15, Figure 4). No orientation of crystals on outer surface or cross-section seen (Plate 5, Figures 2, 4).

Inner layer formed by smaller and apparently more regular in size crystals, resulting in a smooth inner surface (Plate 5, Figure 3). Becomes reduced in thickness towards apertural area (Plate 15, Figure 1). Pores of inner surface smaller compared to those of outer layer.

Aperture as a rule very large, circular to slightly irregular in circumference. Both inner and outer layers usually visible along rim. Apertural rim rough, shaped by individual crystal faces.

The specimen figured on Plate 15, Figures 5, 6 indicates that the test represents a cyst stage. An operculum still loosely attached covers the aperture. It is part of the slightly elongate test. Occasional specimens are seen without aperture, apparently representing forms prior to detachment of the operculum.

Dimensions of holotype: Diameter 62, aperture $32 \mu$.

Locality of figured specimens: Sample 27-259-12-2, 60-62 cm (holotype). See explanations Plates 5,14 , and 15 for paratypes. Eastern side of Perth Abyssal Plain, at foot of continental slope, Indian Ocean, $29^{\circ} 37^{\prime} \mathrm{S}, 112^{\circ} 42^{\prime} \mathrm{E}$. Water depth 4712 meters, depth below sea floor 105 meters.

Age/range of species: Middle Albian (based on calcareous nannoplankton), Albian (based on planktonic foraminifera), upper Albian (based on benthonic foraminifera).

Lithology of type sample: Stiff, yellowish-brown, zeolite- and nanno-bearing clay.

Name: The species is named for Franca Proto-Decima, DSDP Leg 27 paleontologist; University of Padova, Padova, Italy.

Pithonella heirtzleri Bolli, n. sp.

(Plate 5, Figures 5-8; Plate 15, Figures 7-12; Plate 16, Figures 1-4; Plate 23, Figure 2)

Description of species: Test spherical to very slightly elongate. Wall formed by three layers of calcite crystals; outer and middle being of near equal thickness, $5 \mu$ each. Inner layer very thin, peel-like, a fraction of a micron in thickness.

Outer layer formed by crystals irregular in shape and size, somewhat loosely arranged. No preferred orientation of crystals recognizable. Crystals on the outer surface often covered by small pustules (Plate 5, Figure 6; Plate 15, Figure 10) and occasionally also by elevated rims along crystal edges (Plate 16, Figures I, 2). Middle layer consisting of small, closely packed elongate crystals arranged crosswise (Plate 5, Figure 8). Its outer surface compact, showing ends of each small crystal and giving it a cobblestone pattern (Plate 16, Figure 4). Inner surface of middle layer similar to that of outer layer (Plate 16, Figure 2 , upper to right).

Inner layer very thin, smooth, consisting of comparatively large angular, calcite plates covering most of the surface (Plate 5, Figure 7; Plate 16, Figures 1, 3). Aperture small, circular, its rim formed by outer layer (Plate 5, Figure 5; Plate 15, Figures 7, 8). Crystals forming apertural rim of a somewhat platy appearance (Plate 15, Figure 8).

Dimensions of holotype: Diameter 52, aperture $15 \mu$.

Locality of figured specimens: Sample 27-259-12-2, 60-62 cm (holotype). See explanations Plates 5,15 , and 16 for paratypes. Eastern side of Perth Abyssal Plain, at foot of continental slope, Indian Ocean, $29^{\circ} 37^{\prime} \mathrm{S}, 112^{\circ} 42^{\prime} \mathrm{E}$. Water depth 4712 meters, depth below sea floor 105 meters.

Age/range of species: Middle Albian (based on calcareous nannoplankton), Albian (based on planktonic foraminifera), upper Albian (based on benthonic foraminifera).

Lithology of type sample: Stiff, yellowish-brown, zeolite- and nanno-bearing clay.

Name: The species is named for James R. Heirtzler, DSDP Leg 27 co-chief scientist; Woods Hole Oceanographic Institution, Woods Hole, Massachusetts.

Pithonella veeversi Bolli, n. sp.

(Plate 5, Figures 9-12; Plate 16, Figures 5-12; Plate 23, Figure 3)

Description of species: Test distinctly elongate, circular in axial cross-section, posterior end rounded to subrounded, anterior end open with large aperture. Width/length ratio approximately 1:2.

Wall formed of one layer, measuring about 5-6 $\mu$ in thickness, consisting of calcite crystals with long axis regularly perpendicular to test surface. Length of individual crystals equivalent to wall thickness. On inner surface crystal faces well developed (Plate 5, Figures 11, 12; Plate 16, Figure 8), on outer surface more or less strongly eroded (Plate 16, Figures 6, 11, and 12). Edging marks (small rounded pits, clearly visible in Plate 5, Figure 10 and Plate 16, Figure 12) may be present on crystals of outer surface. Some crystal faces of inner surface with triangular-shaped holes at their base (Plate 16, Figure 8). Length/width ratio of individual crystals approximately $4: 1$.

Aperture large, almost equal to diameter of test. Apertural rim mostly somewhat irregular, determined by individual crystal faces (Plate 16, Figure 10).

Dimensions of holotype: Length 74 , width 40 , aperture $24 \mu$.

Locality of figured specimens: Sample 27-259-13-2, 60-62 cm Eastern side of Perth Abyssal Plain, at foot of continental slope, Indian Ocean, $29^{\circ} 37^{\prime} \mathrm{S}, 112^{\circ} 42^{\prime} \mathrm{E}$. Water depth 4712 meters, depth below sea floor 114.5 meters.

Age/range of species: Middle Albian (based on calcareous nannoplankton), upper Albian (based on benthonic foraminifera), Albian (based on Planktonic foraminifera).

Lithology of type sample: Stiff, zeolite-rich nanno clay, predominantly light brown to yellowish-brown with streaks and smears of green clay.

Name: The species is named for John J. Veevers, DSDP Leg $27 \mathrm{co-}$ chief scientist; Macquarie University, North Ryde, N.S.W., Australia.

Pithonella quiltyi Bolli, n. sp.

(Plate 6, Figures 1-4; Plate 17, Figures 1-12; Plate 23, Figure 4)

Description of species: Test variable, spherical to distinctly

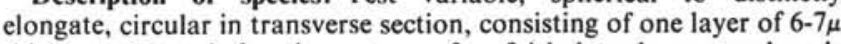
thickness. Crystals forming outer surface fairly loosely arranged, ends subangular to subrounded without distinct faces. Their size is fairly regular, $\pm 1 \mu$. In section, the crosswise arranged crystals distinetly elongate, in some their long axis about equivalent to wall thickness (Plate 6, Figure 4; Plate 17, Figures 7, 12), but mostly shorter. Crystals forming inner surface are slightly thinner but also elongate in shape and crosswise arranged. Ends of these crystals are smaller, more rounded, and with wider interspaces (Plate 6, Figure 3) compared with those forming outer surface. Crystals forming inner layer are irregularly interlocked with crystals of outer surface.

Aperture circular and variable in size. May be absent altogether (Plate 17, Figures 4, 9) or may be almost as wide as diameter of elongate specimens (Plate 17, Figures 5, 6).

Dimensions of holotype: Diameter 67, aperture $31 \mu$.

Locality of holotype: Sample 27-259-12-2, 60-62 cm (holotype). See explanations Plates 6 and 17 for paratypes. Eastern side of Perth 
Abyssal Plain, at foot of continental slope, Indian Ocean, $29^{\circ} 37^{\prime} \mathrm{S}$, $112^{\circ} 42^{\prime} \mathrm{E}$. Water depth 4712 meters, depth below sea floor 105 meters.

Age/range of species: Middle Albian (based on calcareous nannoplankton), Albian (based on planktonic foraminifera), upper Albian (based on benthonic foraminifera).

Lithology of type sample: Stiff, yellowish-brown, zeolite- and nanno-bearing clay

Name: The species is named for Patrick G. Quilty, Paleontologist; Western Australian Petroleum Company, Perth, Australia.

Pithonella johnstonei Bolli, n. sp.

(Plate 6, Figures 5-8; Plate 18, Figures 1, 2; Plate 23, Figure 5)

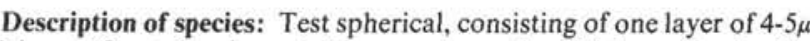
thickness. Crystal ends as visible on outer surface fairly regular in size, $1-2 \mu$, angular and fairly tightly packed with only small interspaces. In cross-section the elongate crystals are distinctly crosswise arranged, at angles of approximately $90^{\circ}$ (Plate 6, Figure 8). Crystal faces are better developed on inner surface and appear more irregular in size compared with outer surface. Interspaces between crystals are wide (Plate 6, Figures 7, 8; Plate 18, Figure 2). Aperture small, circular. Dimensions of holotype: Diameter 45 , aperture $12 \mu$.

Locality of figured specimens: Sample 27-260-6-1, 46-48 cm. Gascoyne Abyssal Plain, at foot of Exmouth Plateau, Indian Ocean, $16^{\circ} 09^{\prime} \mathrm{S}, 110^{\circ} 18^{\prime} \mathrm{E}$. Water depth 5709 meters, depth below sea floor 177.5 meters.

Age/range of species: Upper Cretaceous, probably Coniacian to Santonian. This age assignment is based on a poor planktonic foraminiferal fauna that occurs in Core 6 with the Calcisphaerulidae and the characteristic benthonic agglutinated foraminifera described in this volume by $\mathrm{K}$ rasheninnikov. Diagnostic planktonic species present are: very scarce Rotalipora apenninica, more frequent Globotruncana lapparenti aff. coronata and $G$. lapparenti lapparenti. From the heterogeneous composition of the planktonic foraminiferal species and the character of the sediment, probably deposited below the lysocline, it is assumed that the entire planktonic foraminiferal fauna is redeposited. The true age of the sediment is therefore difficult to assess. The presence of species of the $G$. lapparenti group indicates an age not older than Coniacian. The absence of species characterizing Campanian and younger sediments (Globotruncana stuartiformis, G. elevata. $G$. contusa, etc.) may be taken as an indication that the sediments are not younger than Santonian, although reworking of the species present into sediments of an age younger than Santonian cannot entirely be excluded. Because of their calcareous test and their apparent planktonic nature, the Calcisphaerulidae in Sample 6-1, 46$48 \mathrm{~cm}$, are assumed to also have been redeposited. If they are age equivalent with the predominant Globotruncana species of the lapparenti group of Core 6 , which appears likely, they are dated as Coniacian to Santonian.

Lithology of type sample: Dark, grayish-brown, stiff zeolite-bearing clay.

Name: The species is named for Murray $H$. Johnstone, chief geologist, Western Australian Petroleum Company, Perth, Australia.

Pithonella cooki Bolli, n. sp.

(Plate 6, Figures 9-12; Plate 18, Figures 3-9; Plate 23, Figure 6)

Description of species: Test variable, spherical to moderately elongate, circular in transverse section, width/length ratio 1:1 to 2.3:3. Wall formed by two layers of calcite crystals. Outer, much thinner layer, about $2 \mu$, inner about $7 \mu$ thick. Crystals on outer surface fairly uniform in size, with indistinct faces, cobblestone pattern (Plate 6, Figure 10; Plate 18, Figures 4, 7). Inner layer similar to that of Pithonella krasheninnikovi, with closely packed crystals of variable sizes and with well-developed end faces (Plate 6, Figure 11).

Long axis of crystals perpendicular to surface (Plate 6, Figure 12). Inner layer may become thinner in apertural area where it may be partially overlapped by outer layer.

A perture circular, of medium size, its rim determined by individual crystals of outer layer (Plate 18, Figures 1,6).

Dimensions of holotype: Length 78 , width 54 , aperture $18 \mu$.

Locality of figured specimens: Sample 27-260-6-1, 46-48 cm. Gascoyne Abyssal Plain, at foot of Exmouth Plateau, Indian Ocean, $16^{\circ} 09^{\prime} \mathrm{S}, 110^{\circ} 18^{\prime} \mathrm{E}$. Water depth 5709 meters, depth below sea floor 177.5 meters.

Age/range of specimens: Upper Cretaceous, probably Coniacian to Santonian (based on planktonic foraminifera, see remarks under Pithonella johnstonei).
Lithology of type sample: Dark, grayish-brown, stiff, zeolitebearing clay

Name: The species is named for Peter J. Cook, DSDP Leg 27 sedimentologist; Bureau of Mineral Resources, Canberra, Australia.

Pithonella krasheninnikovi Bolli, n. sp.

(Plate 7, Figures 1-5; Plate 18, Figures 10-12; Plate 19,

Figures 1-12; Plate 20, Figures 1-4; Plate 24, Figures 1, 2)

Description of species: Test distinctly elongate, ends subrounded to rounded, circular in transverse section, width/length ratio approximately $1: 2$. Formed by two layers whose calcite crystals are well preserved. Outer layer measures approximately $2 \mu$ inner about $7 \mu$ in thickness. Outer layer may be partially (Plate 19, Figures 1, 2, 4-6) or completely (Plate 19, Figures 7, 10; Plate 20, Figure 1) missing which is probably due to mechanical damage or, more likely, to solution effects. Outer layer consisting of plate-shaped calcite crystals of approximately $2-4 \mu$ length, $2-3 \mu$ height, and $1 \mu$ width. Large faces perpendicular to test surface (Plate 19, Figures 2, 3, 4), orientation apparently to some degree dependent on orientation of crystal faces of inner layer, on which they rest (Plate 7, Figure 3; Plate 19, Figures 2, 4, 8). Probably from this results a certain alignment pattern of outer layer crystals which are loosely arranged, resulting in empty angular spaces between crystals (Plate 7 , Figure 2).

Inner layer consisting of closely packed crystals of variable size with long axis perpendicular to surface (Plate 7, Figures 3, 5; Plate 19, Figure 6). Crystal faces, usually three for each crystal, may be well developed on outer surface (Plate 7, Figure 3; Plate 19, Figures 7, 8; Plate 20, Figures 1,2). In some specimens, crystal faces may be corroded or edged (Plate 19, Figures 10,11). On inner surface crystals show a similar development and preservation as on outer surface (Plate 7, Figures 4, 5; Plate 19, Figure 12).

Aperture situated at one end, circular, may be absent in some specimens. The specimen figured on Plate 20, Figures 3,4 is less elongate compared with the average. Here, the small platy crystals of the outer layer are interspaced by few distinctly larger crystals without distinct faces. The outer layer crystals of the specimen shown on Plate 19 . Figure 9 are slightly more massive and slightly more compactly arranged than in the other figured specimen (Plate 7, Figure 2).

Dimensions of holotype: Length 120 , width 60 , aperture $18 \mu$.

Locality of figured specimens: Sample 27-260-6-1, 46-48 cm. Gascoyne Abyssal Plain, at foot of Exmouth Plateau, Indian Ocean, $16^{\circ} 09^{\prime} \mathrm{S}, 110^{\circ} 18^{\prime} \mathrm{E}$. Water depth 5709 meters, depth below sea floor 177.5 meters.

Age/range of species: Upper Cretaceous, probably Coniacian to Santonian (based on planktonic foraminifera, see remarks under Pithonella johnstonei).

Lithology of type sample: Dark, grayish-brown, stiff zeolite-bearing clay.

Name: The species is named for Valeri A. Krasheninnikov, DSDP Leg 27 paleontologist; Academy of Sciences of the USSR, Moscow.

\section{Pithonella sp. A}

\section{(Plates 7, Figures 9-12; Plate 20, Figures 10-12; Plate 23, Figure 4)}

Description of species: Test elongate, amphora shaped, circular in transverse section. Immediately below aperture slightly restricted in diameter. Distal end fairly pointed with a small circular second aperture (Plate 7, Figure 9; Plate 20, Figures 11, 12). Thickness of the wall in apertural rim $4 \mu$. Outer surface smooth with small irregular holes but with no individual crystal faces distinguishable. Inner ends of crystals appear smaller, leaving some interspaces on the smooth inner surface (Plate 7, Figures 11, 12).

Aperture large, circular, rim rough. Second aperture at distal end small, circular, rim smooth.

Only a single specimen has been found so far which is here provisionally included in Pithonella, despite the fact that a second aperture is apparently present.

Dimensions of figured specimen: Length 64 , width 45 , aperture $24 \mu$. Aperture at distal end $8 \mu$.

Locality of figured specimen: Sample 27-263-3, CC, basal part. Eastern edge of Cuvier Abyssal Plain, Indian Ocean, $23^{\circ} 20^{\prime} \mathrm{S}$, $110^{\circ} 58^{\prime} \mathrm{E}$. Water depth 5065 meters, depth below sea bottom 100 meters.

Age/range of species: Reworked in Tertiary, together with the following Lower Cretaceous fossils: upper Albian (based on calcareous nannoplankton), ?lower Albian (based on benthonic 
foraminifera), Barremian to upper Aptian or lower Albian (based on dinoflagellates).

Lithology of sample: Black, clayey nanno ooze.

\section{Pithonella sp. B}

(Plate 7, Figures 6-8; Plate 20, Figure 9; Plate 24, Figure 3)

Description of species: Test spherical, formed by single layer, $3 \mu$ thick in apertural rim. Surface formed by well-developed, small, but irregularly sized calcite crystals, their ends composed of three principal faces (Plate 20, Figure 7).

In cross-section individual crystals elongate with long axis in radial position that also equals the thickness of test wall (Plate 20, Figure 8). Aperture circular.

The single specimen found compares closely with $P$. gustafsoni from which it differs on the outer surface by the individual crystal faces being well developed with distinct edges, while in P. gustafsoni the crystal ends appear subangular to subrounded and with more faces on each crystal. Further, Pithonella sp. B occurs in a different stratigraphic level.

Dimensions of figured specimen: Diameter 60, aperture $26 \mu$.

Locality of figured specimen: Sample 27-260-6-1, 46-48 cm. Gascoyne Abyssal Plain, at foot of Exmouth Plateau, Indian Ocean, $16^{\circ} 09^{\prime} \mathrm{S}, 110^{\circ} 18^{\prime} \mathrm{E}$. Water depth 5709 meters, depth below sea floor 177.5 meters.

Age/range of specimen: Upper Cretaceous, probably Coniacian to Santonian (based on planktonic foraminifera, see remarks under Pithonella johnstonei).

Lithology of sample: Dark, grayish-brown, stiff zeolite-bearing clay.

Pithonella sp. C

(Plate 20, Figures 5, 6; Plate 23, Figure 5)

Description of species: Test elongate, circular in transverse section, length/width ratio 3.5:2.4, apparently consisting of one layer. On

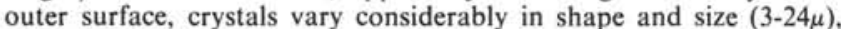
many being very large compared with size of test. Distribution of small and large components irregular, with crystals of each size grouped together.

Aperture fairly large, somewhat irregular in shape. Rim formed by crystals of different sizes. Only a single specimen of this kind has been observed.

Dimensions of figured specimen: Length $73 \mu$, width $44 \mu$, aperture $18 \mu$.

Locality of figured specimen: Sample 27-259-6-1, 46-48 cm. Eastern side of Perth Abyssal Plain, at foot of continental slope, Indian Ocean, $29^{\circ} 37^{\prime} \mathrm{S}$, $112^{\circ} 42^{\prime} \mathrm{E}$. Water depth 4712 meters, depth below sea floor 177.5 meters.

Age/range of specimen: Upper Cretaceous, probably Coniacian to Santonian (based on planktonic foraminifera, see remarks under Pithonella johnstonei).

Lithology of sample: Dark, grayish-brown, stiff zeolite-bearing clay.

\section{Pithonella sp. D}

(Plate 20, Figures 7, 8; Plate 23, Figure 6; Plate 24, Figure 6)

Description of species: Test distinctly elongate, circular in transverse section, length/width ratio $2: 1$. Rounded at distal end, towards apertural area narrowing in diameter. Surface formed by irregular in size, somewhat corroded calcite crystals giving it a rough appearance. Apertural rim, unlike other Pithonella sp. described here, formed by five large curvilinear individual but closely attached crystals, much larger and different in size from those forming test. They surround aperture in form of a ring (Plate 20, Figures 7,8).

Only a single-specimen of this kind has been found.

Dimensions of figured specimen: Length 100 , width 50 , aperture $10 \mu$.

Locality of figured specimen: Sample 27-260-6-1, 46-48 cm. Gascoyne Abyssal Plain, at foot of Exmouth Plateau, Indian Ocean, $16^{\circ} 09^{\prime} \mathrm{S}, 110^{\circ} 18^{\prime} \mathrm{E}$. Water depth 5709 meters, depth below sea floor 177.5 meters.

Age/range of specimen: Upper Cretaceous, probably Coniacian to Santonian (based on planktonic foraminifera, see remarks under Pithonella johnstonei).

Lithology of sample: Dark, grayish-brown, stiff zeolite-bearing clay.

\section{ACKNOWLEDGMENTS}

The author wishes to thank the Deep Sea Drilling Project for having given him the opportunity to participate on Glomar Challenger Leg 27 cruise in the Eastern Indian Ocean Between Australia and Indonesia. Though originally taking part as a foraminiferal paleontologist, the main interest of the writer was shifted during the leg towards the study of Calcisphaerulidae, which, rather unexpectedly, were recovered in great numbers and in well-preserved and isolated form from Jurassic and Cretaceous sediments.

Onboard ship, the writer discussed many aspects concerning Calcisphaerulidae with Franca Proto Decima (Padova) and V. A. Krasheninnikov (Moscow), whose advice proved to be most valuable during the early stage of the work. Special thanks go to H. E. Franz of the Geology Department, Swiss Federal Institute of Technology, Zurich. He took some 800 SEM photographs to permit the detailed study of the Pithonella species as presented here. In addition, H. E. Franz, and also H. U. Nissen (Zurich), provided important assistance in the description of the species. The here-described forms and their systematic position were discussed with $\mathrm{R}$. Lehmann (Bordeaux), Helen and Alfread R. Loeblich-Tappan (Los Angeles), J. Remane (Neuchatel), and F. Rögl (Zurich). Beatrice Lüthi, W. Petter, and G. Pupp of the Crystallography Department, Swiss Federal Institute of Technology, Zurich, kindly provided X-ray powder diagrams for some Pithonella species, in order to identify the mineralogical composition of their tests. J. P. Beckmann (Zurich) and P. T. Robinson (Riverside) critically read and discussed the manuscript, which was typed by Franziska Wechsler (Zurich). The photographic work was carried out by U. Gerber of the Geology Department, Swiss Federal Institute of Technology, Zurich.

The writer wishes to extend his gratitude to all these persons who helped in the preparation of the paper.

Finally, he wishes to acknowledge that the Swiss Federal Institute of Technology kindly granted him the necessary leave of absence to participate in Leg 27, and after the cruise, placed at his disposal SEM, laboratory, photographic, and clerical facilities.

\section{REFERENCES}

Adams, T. D., Khalili, M., and Khosrovi Said, A., 1967. Stratigraphic significance of some oligosteginid assemblages from Lurestan Province, northwest Iran: Micropaleontology, v. 13, p. 55-67.

Andri, E., 1972. Mise au point et données nouvelles sur la famille des calcisphaerulidae Bonet 1956: les genres Bonetocardiella, Pithonella, Calcisphaerula et "Stomiosphaera". Rev. Micropaléontol., v. 15, p. 12-34.

Ayala-Castanares, A. and Seiglie, G. A., 1962. Stomiosphaera cardiiformis sp. nov. del Cretacico superior de Cuba: Paleontol. Mexicana, v. 12, p. 11-22.

Azema, J., 1966. Stratigraphie: Observations sur la microfaune du Crétacé supérieur de la région de Fortuna, Prébétique méridional (province de Murcie, Espagne): C. R. Acad. Sci. Paris., v. 262, p. $838-840$.

Banner, F. T., 1972. Pithonella ovalis from the early Cenomanian of England: Micropaleontology, v. 18, p. 278284.

Bignot, G. and Lézaud, L., 1964. Contribution à l'étude des Pithonella de la craie parisienne: Rev. Micropaléontol., v. 7, p. 138-152.

Bonet, F., 1956. Zonificacion microfaunistica de las calizas cretacicas del este de Mexico: Internatl. Geol. Congr., 20th, p. 3-102. 
Bonet, F. and Trejo, M., 1958. Nuevos datos sobre la Familia Calcisphaerulidae (Protozoa): Anal. Esc. Nac. Cienc. Biol., v. 9 , p. $43-48$.

Borzka, K., 1964.DieGattung Stomiosphaera Wanner, 1940 in den Westkarpaten: Geol. Sbornik, Slov. Akad., v. 15, p. $189-195$.

1969. Die Mikrofazies und Mikrofossilien des Oberjuras und der Unterkreide der Klippenzone der Westkarpaten: Verlag Slowak. Akad. Wiss., p. 1-301.

1972. Neue Arten der Gattungen Cadosina Wanner, Pithonella Lorenz und Palinosphaera Reinsch aus der oberen Kreide: Geol. Sbornik, Geol. Carpathica, v. 23, p. 139-150.

Bothé, A. Chr. D., 1927. Voorloopige mededeeling betreffende de Geologie van Zuidost-Celebes: De Myningenieur, v. 8.

Bramlette, M. N. and Martini, E., 1964. The great change in calcareous nannoplankton fossils between the Maestrichtian and Danian: Micropaleontology, v. 10 (3), p. 291.

Brouwer, H. A., 1919. Geologische Onderzoekingen in OostCeram: Tydschr. v.h.K. Nederl. Aardr. Gen. (2), v. 36, p. 715-750.

Colom, G., 1969. Globulinites tripartitus, microorganismo incertae sedis de las calizas del Lias inferior de Mallorca: Rev. Esp. Micropaleontol., v. 1, p. 13-17.

Colom, G. and Allard, P. L. 1958. Présence au Maroc des microorganismes de Wanner: Rev. Micropaléontol., v. 1, p. 31-32.

Dufour, M. T., 1968. Quelques remarques sur les organismes incertae sedis de la famille des Calcisphaerulidae Bonet (1956): C. R. Acad. Sci. Paris, V. 266, p. 1947-1949.

Durand Delga, M., 1957. Quelques remarques sur les fibrosphères: Serv. Carte Géol. Algérie, v. 13, p. 153-164.

Egger, J. G., 1909. Foraminiferen der Seewener Kreideschicten: Verh. Kgl. Bayer Akad. Wiss. Math.-Phys. KI. Abh., v. 11, p. 1-51.

Haq, U. Z. B. and Lipps, J. H., 1971. Calcareous nannoplankton. In Tracey, J. I., Jr., et al., Initial Reports of the Deep Sea Drilling Project, Volume 8: Washington (U.S. Government Printing Office), p. 777.

Heer, O., 1865. Urwelt der Schweiz. Friedrich Schulthess, Zürich, 1-622.

Keller, B. M., 1946. The foraminifera of the Upper Cretaceous deposits in the Sotehi Region: Soc. Nat. Moscow, Bull. v. 21 , p. 83-108.

Knauer, J., 1970. Calcisphaerula, Pithonella and Stomiosphaera from Middle Cretaceous beds of the Bakony Mountains: Hungarian Geol. Soc. Bull., v. 100, p. 8890.

Lapparent, J. de, 1918. Etude lithologique des terrains crétacé de la region d'Hendaye: Serv. Carte Géol. France Mém., p. $1-155$.

1924. Les calcaires a Globigérines du Crétacé supérieur et des couches de passage à l'Eocéne dans les Pyrénées occidentales: Soc. Géol. France, Bull. v. 24, p. 615-641.

Leischner, W., 1961. Zur Mikrofacies kalkalpiner Gesteine: Oesterr. Akad. Wissensch. Math. Natur. KI. Sitz.-Ber. B I, 168 , Wien.

Locker, S., 1967. Die Sphären der Oberkreide und die sogenannte Orbulinaritfazies: Geologie, v. 16, p. 850-859.

Loczy, L. v., 1934. Geologie van Noord-Boengkoe en het Bongkagebiet tusschen de golf van Tomini en de golf van Tolo in Oost-Celebes: Verh. Geol. Mynb. Gen. Nederland. Geol. Ser., v. 10, p. 219-322.

Lorenz, T., 1901. Geologische Studien im Genzgebiete zwischen helvetischer und ostalpiner Fazies: Ber. Natf. Ges. Freiburg i. Br., v. 12, p. 34-95.
Mark, W. von der, 1958. Die Diluvial- und AlluvialAblagerungen im Innern des Kreidebeckens von Münster: Verh. Naturhist. Verein Rheinland. u. Westphal., 15, NF 5, p. 1-75.

, 1871. Ueber fossile Coccolithen und Orbulinen der oberen westfälischen Kreide: Verh. Naturhist. Verein Rheinland. u. Westphal., 28, 3. Folge, v. 8, p. 60-63.

Nagy, I., 1966. A stomiosphaera és a cadosina nemzetség rétegtaini szerepe a mecseki felsöjuraban: Hung. Geol. Soc. Bull., v. 96, p. 86-104.

Nowak, W., 1968. Stomiosphaerids of the Cieszyn Beds (Kimmeridgian-Hauterivian) in the Polish Cieszyn Silesia and their stratigraphic value: Ann. Soc. Géol. Pologne, v. 38 , p. $275-327$.

Perch-Nielsen, K., 1972. Remarks on Late Cretaceous to Pleistocene coccoliths from the North Atlantic. In Laughton, A. S., Berggren, W. A. et al., Initial Reports of the Deep Sea Drilling Project, Volume 12: Washington (U.S. Government Printing Office), p. 1003.

Reinsch, P. F., 1905. Die Palinosphären, ein mikroskopischer vegetabiler Organismus in der Mucronatenkreide: Centralblatt f. Min., Geol. Pal., v. 1, p. 402-407.

Schiller, J., 1930. Coccolithineae: Leipzig Akad. Verlag, 1, p. 1-273.

Seguenza, G., 1862. Notizie succinte intorno alla costituzione geologica dei terreni Terziarii del Distretto di Messina.

Stradner, H., 1973. Catalogue of Calcareous nannoplankton from sediments of Neogene age in the eastern North Atlantic and Mediterranean Sea. In Ryan, W. B. F., Hsu, K. J. et al., Initial Reports of the Deep Sea Drilling Project, Volume 13: Washington (U.S. Government Printing Office), p. 1137.

Tan Sin Hok, 1927. Over de Samenstelling en het onstaan van Kryt-en Mergel-Gesteenten van de Molukken: Jarb. Mynwezen Nederl. Oost-Indie 1926.

Vogler, J., 1941. Ober-Jura und Kreide von Misol (Niederländisch-Ostinden): Palaeontographica, v. 4, p.245293.

Voigt, E. and Häntzschel, W., 1964. Gradierte Schichtung in der Oberkreide Westfalens: Fortschr. Geol. Rheinland. Westfalen: v. 7, p. 495-548.

Wanner, J., 1940. Gesteinsbildende Foraminiferen aus Malm und Unterkreide des östlichen Ostindischen Archipels: Pal. Z., v. 22 , p. $75-99$.

\section{PLATES 1-24}

\section{General Explanations}

\section{Plates 1-7, Figures 1-5}

The 19 new species are shown in four figures each $(P$. krasheninnikovi in five), on each plate arranged in vertical order. At the top is the holotype magnified at a uniform diameter, $\times 350-800$, depending on size of specimen. Below follow close-up views of outer surface, inner surface, and cross-section, all at $\times 2500$. Some of these close-up views are from holotypes, others from paratypes.

\section{Plates 7, Figures 6-12; Plate 20, Figures 5-12}

The four species described in open nomenclature are figured in a similar way as the new species. However, some of the close-up views of the inner surface and cross-section could not be shown because one specimen only was available. 


\section{Plates 8-20, Figures 1-4}

Figured are paratypes, close-up views of features of particular interest, and for each species a broken specimen showing the inside surface and wall section.

\section{Plates 21-24}

To show the features of each species, holotypes had to be figured on Plates 1-7 at a fairly low magnification and also had to be spread over seven plates.
Plates 21-24 show the 19 new species and four species in open nomenclature at a magnification about double that of Plates 1-7 and 20. Many features of entire specimen are here better visible, and comparison between holotypes is facilitated.

The specimens figured on Plates 1-24 are deposited in the Museum of Natural History, Basle, Switzerland, under the numbers C 29809 to C 29934. The number for each specimen appears with the species explanations for the plates. 


\section{PLATE 1}

Figures 1-4 Pithonella carteri, Sample 261-31, CC.

1. Apertural view of holotype, $\times 800$, C 29809.

2. Outer surface of holotype, $\times 2500$, C 29809.

3. Inner surface of paratype, $\times 2500, C 29810$.

4. Cross-secti-n of paratype, $\times 2500, C 29811$.

Figures 5-8 Pithonella menighti, Sample 261-31, CC.

5. Side/apertural view of holotype, $\times 800, C$ 29814.

6. Outer surface of holotype

(see also Plate 8, Figure 4), $\times 2500$, C 29814.

7. Inner surface of paratype, $\times 2500, C 29815$.

8 . Cross section of paratype, $\times 2500$, C 29816 .

Figures 9-12 Pithonella thayeri, Sample 261-31, CC.

9. Side/apertural view of holotype, $\times 700, C$ 29820.

10. Outer surface of paratype, $\times 2500$, C 29821 .

11. Inner surface of paratype, $\times 2500$, C 29822 .

12. Cross-section of paratype, $\times 2500$, C 29823 . 
PLATE 1
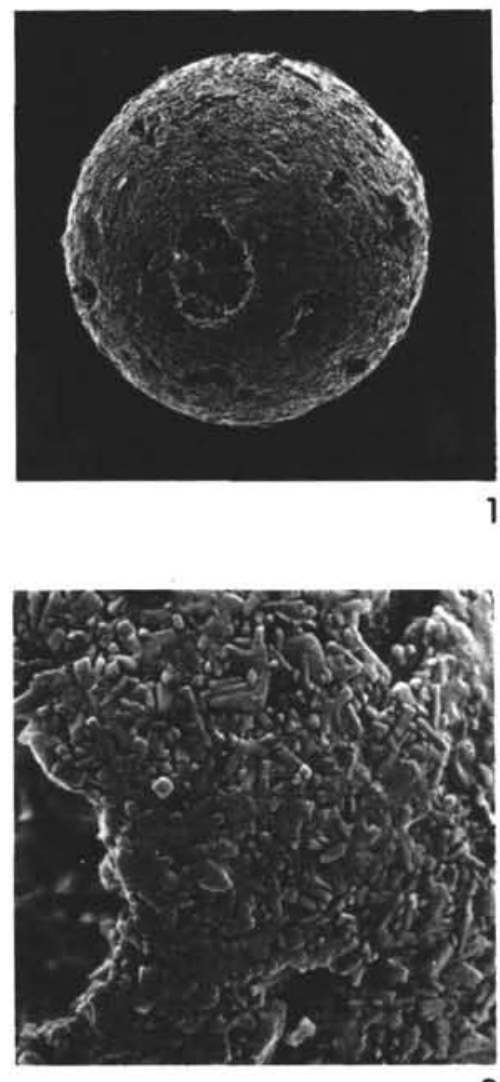

2
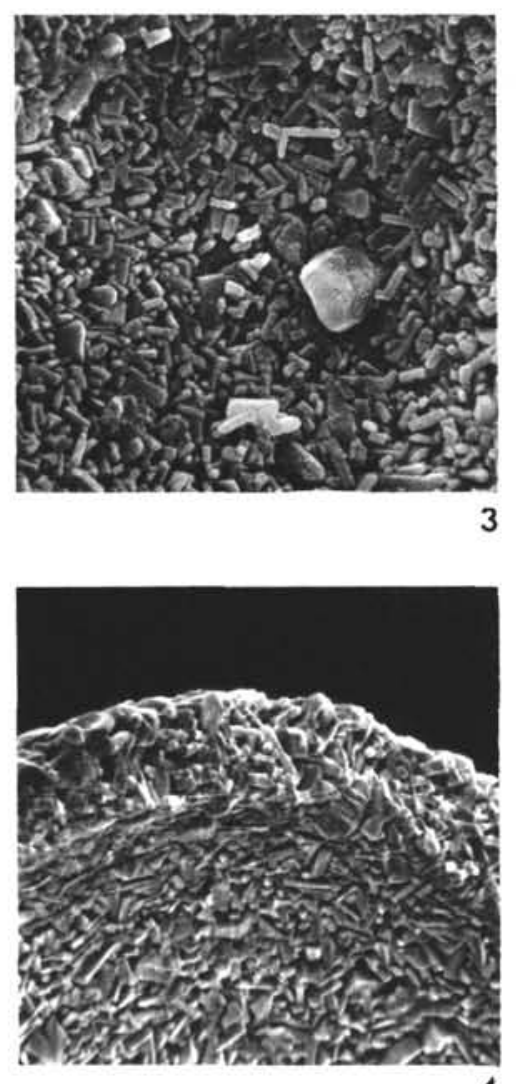
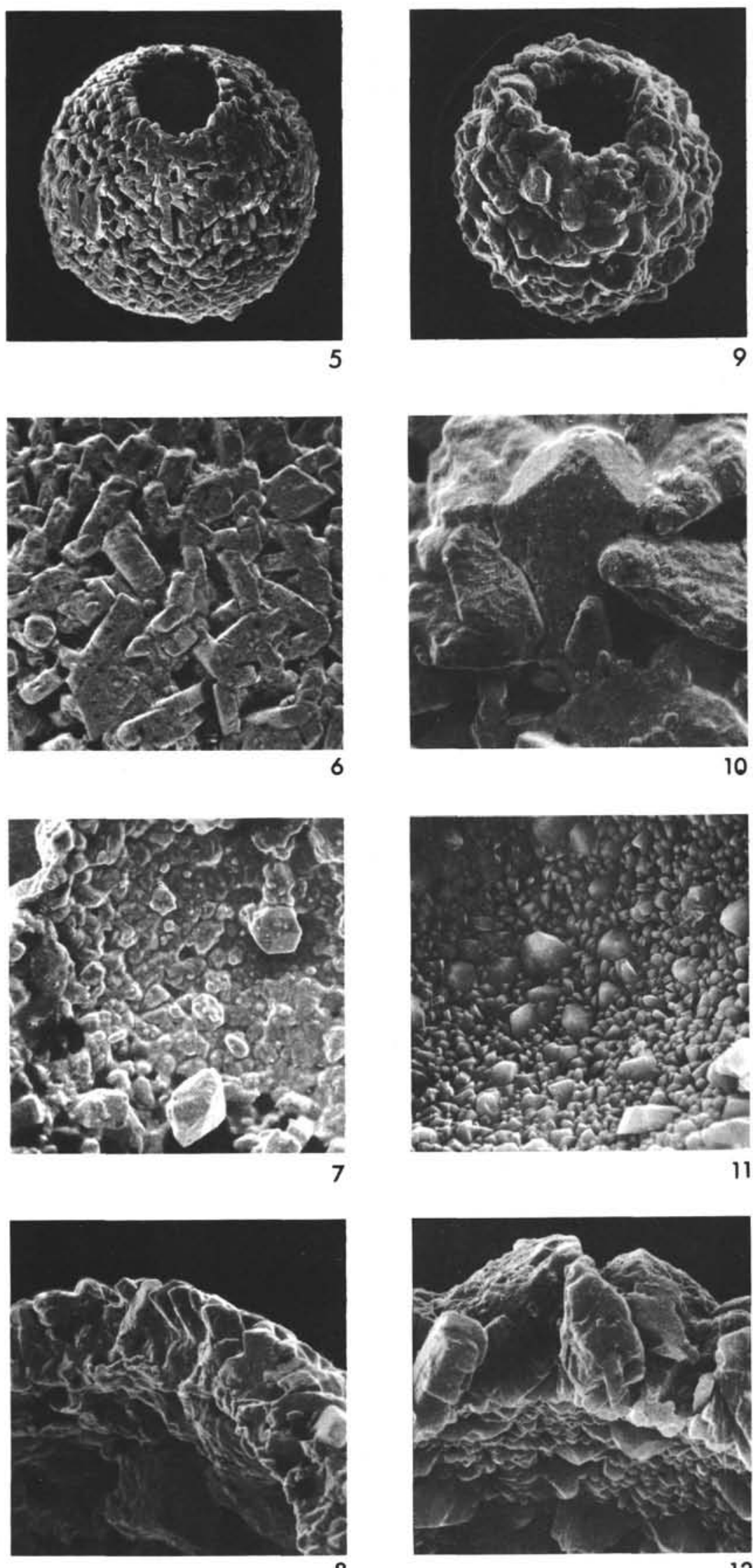


\section{PLATE 2}

Figures 1-4 Pithonella helentappanae, Sample 263-17, CC. 1. Side/apertural view of holotype, $\times 700, \mathrm{C}$ 29834.

2. Outer surface of paratype, $\times 2500$, C 29835 .

3. Inner surface of paratype, $\times 2500, \mathrm{C} 29836$.

4. Cross-section of paratype, $\times 2500, \mathrm{C} 29837$.

Figures 5-8 Pithonella nonarenzae, Sample 263-17, CC.

5. Side/apertural view of holotype, $\times 700, \mathrm{C}$ 29841 .

6. Outer surface of paratype, $\times 2500$, C 29842 .

7. Inner surface of paratype, $\times 2500, C 29843$.

8. Cross-section of paratype, $\times 2500$, C 29844.

Figures 9-12 Pithonella patriciagreeleyae, Sample 263-3, CC.

9. Side/apertural view of holotype, $\times 700, C$ 29848.

10. Outer surface of holotype, $\times 2500$, C 29848 .

11. Inner surface of paratype, $\times 2500$, C 29849.

12. Cross-section of paratype, $\times 2500$, C 29849 . 
PLATE 2
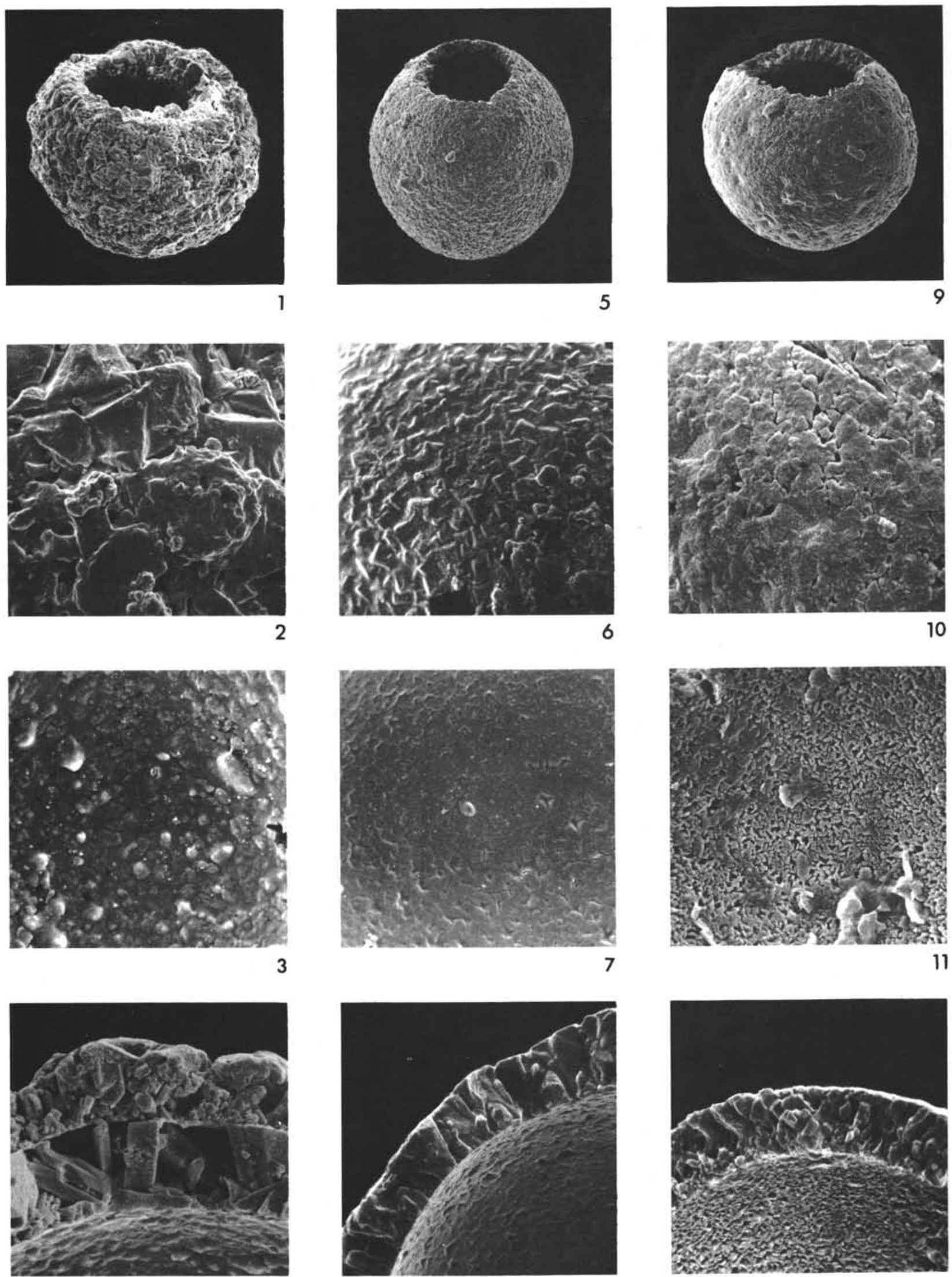


\section{PLATE 3}

Figures 1-4 Pithonella loeblichi, Sample 260-15, CC.

1. Side/apertural view of holotype, $\times 700, C$ 29854.

2. Outer surface of holotype, $\times 2500$, C 29854 .

3. Inner surface of paratype, $\times 2500$, C 29855.

4. Cross-section of paratype, $\times 2500$, C 29856.

Figures 5-8 Pithonella rockeri, Sample 260-12-1, 86-88 cm. 5 . Side/apertural view of holotype, $\times 750, C$ 29859.

6. Outer surface of paratype, $\times 2500$, C 29860 .

7. Inner surface of paratype, $\times 2500, C 29861$.

8. Cross-section of paratype, $\times 2500$, C 29862.

Figures 9-12 Pithonella gustafsoni, holotype from Sample 260-9, CC; paratype from Sample 260-11-1, 100-102 cm.

9. Side/apertural view of holotype

(for detail of apertural area see Plate 12, Figure 9), $\times 800$, C 29863.

10. Outer surface of paratype, $\times 2500$, C 29864.

11. Inner surface of paratype, $\times 2500, C 29865$.

12. Cross-section of paratype, $\times 2500$, C 29866. 


\section{PLATE 3}
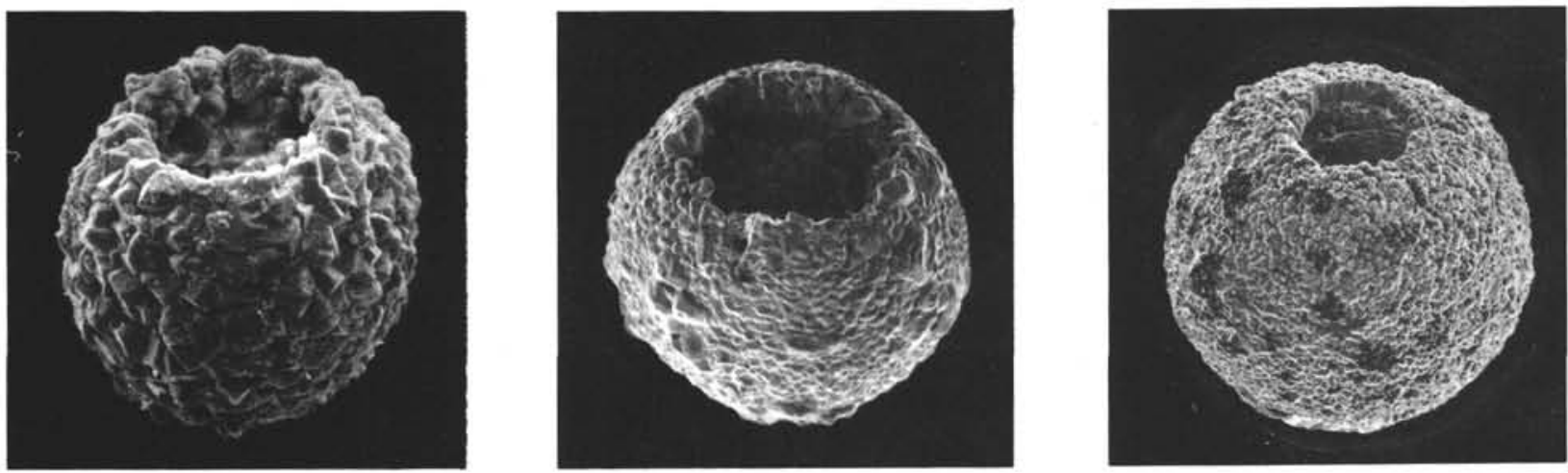

5

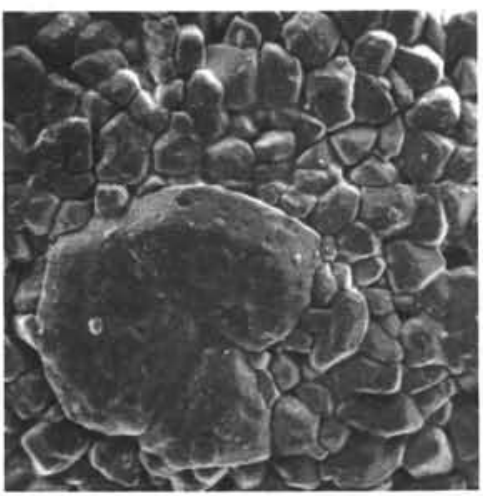

6
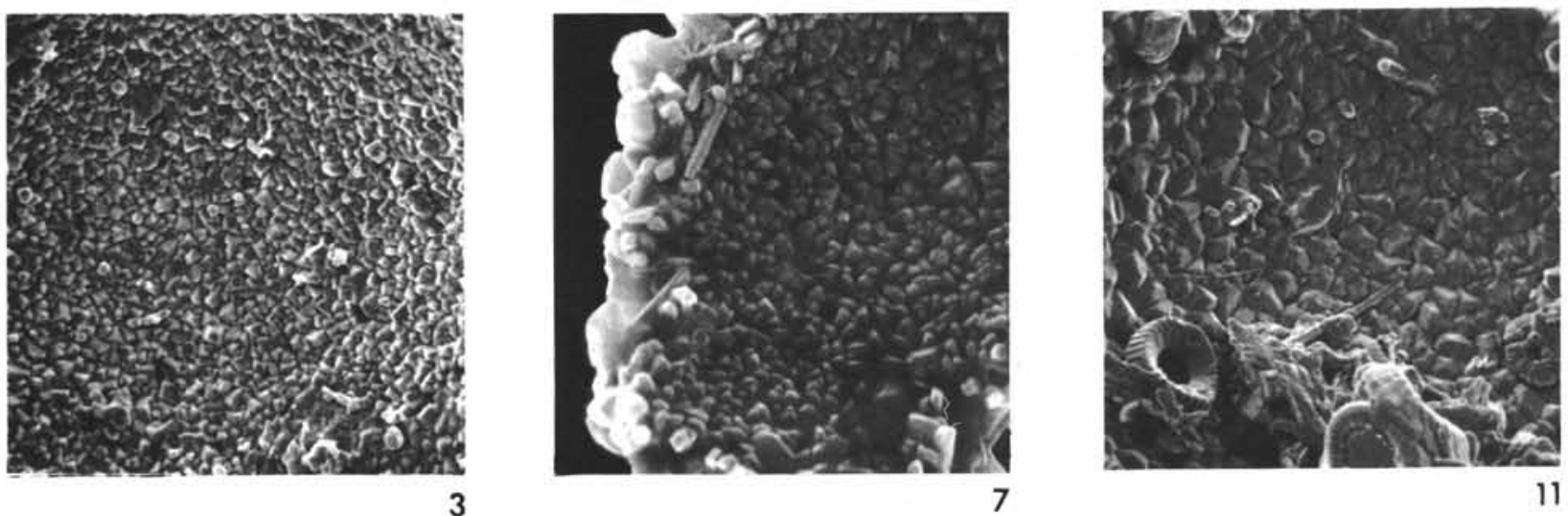

11
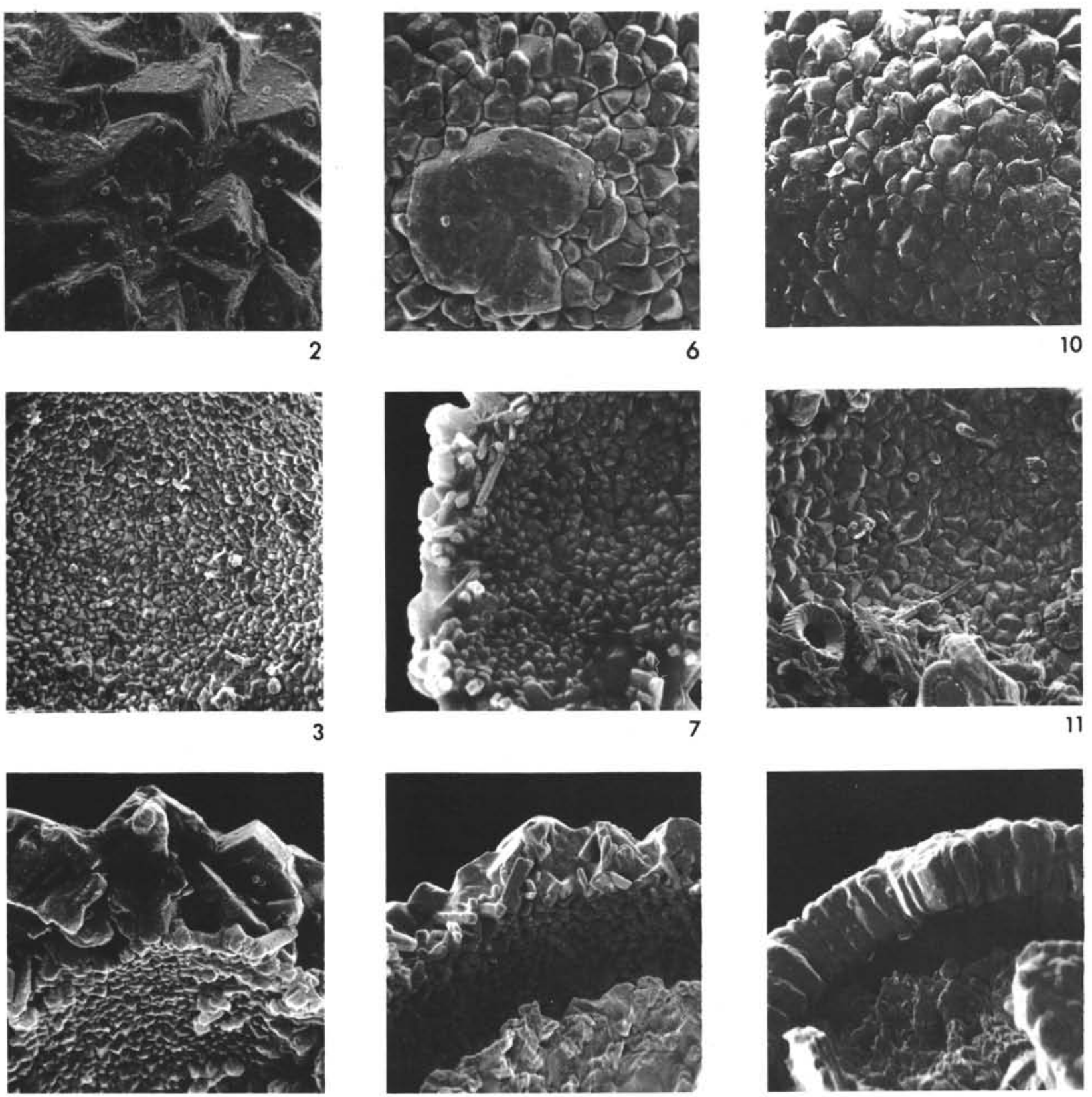


\section{PLATE 4}

Figures 1-4 Pithonella edgari, holotype from Sample 259-15-5, 124-126 cm; paratype from Sample 259-13-2, 60-62 $\mathrm{cm}$.

1. Side view of holotype

(for detail of apertural area see Plate 13, Figure 3), ×750, C 29870.

2. Outer surface of holotype, $\times 2500$, C 29870 .

3 . Inner surface of paratype, $\times 2500$, C 29871.

4. Cross-section of paratype, $\times 2500, C 29871$.

Figures 5-8 Pithonella robinsoni, holotype from Sample 25917-2, 47-49 cm; paratype from Sample 259-17-3, $38-40 \mathrm{~cm}$.

5. Side view of holotype

(for detail of apertural area see Plate 13, Figures 8, 9), ×700, C 29875.

6. Outer surface of holotype, $\times 2500$, C 29875 .

7 . Inner surface of paratype, $\times 2500, \mathrm{C} 29876$.

8. Cross-section of paratype, $\times 2500$, C 29876.

Figures 9-12 Pithonella sheilasantawae, Site 259.

9. Side/apertural view of holotype, $\times 700, C$ 29880.

10. Outer surface of holotype, $\times 2500$, C 29880 .

11. Inner surface of paratype, Sample 17-3, 38-40 $\mathrm{cm}, \times 2500$, C 29881 .

12. Cross-section of paratype, Sample $2-47-49 \mathrm{~cm}$, $\times 2500$, C 29882 . 
PLATE 4

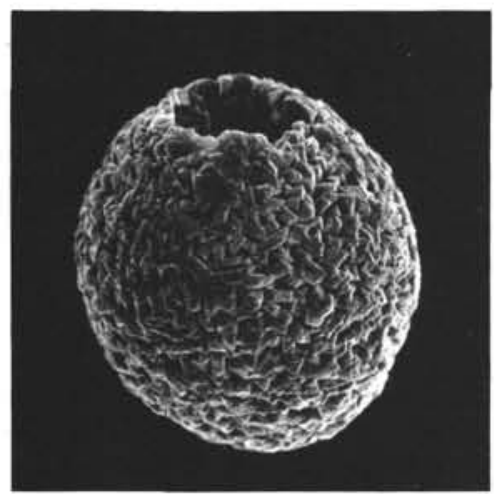

1

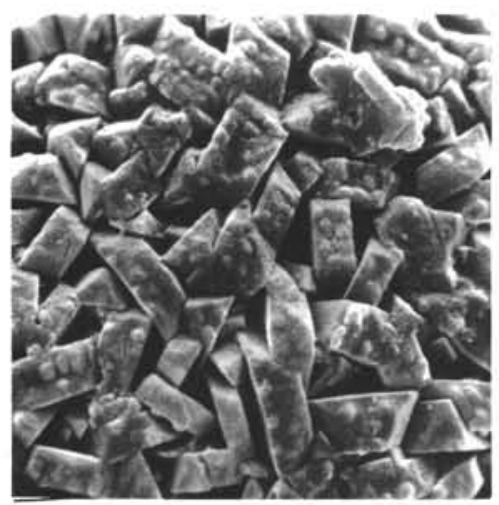

2

-

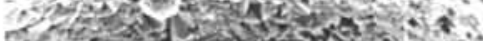

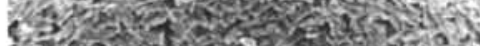

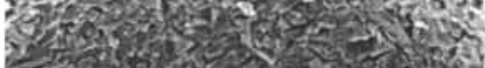

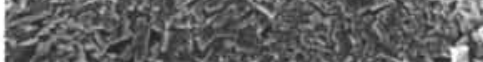

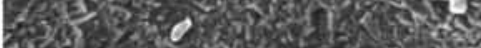
a w M

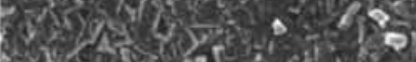

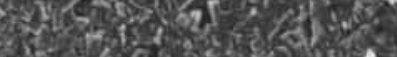

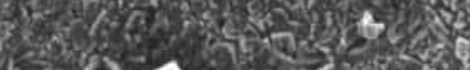

3

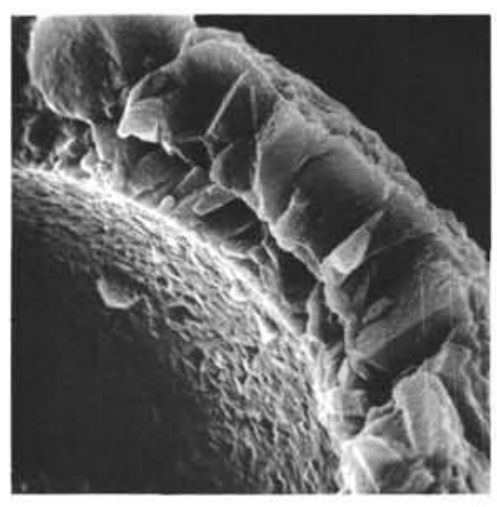

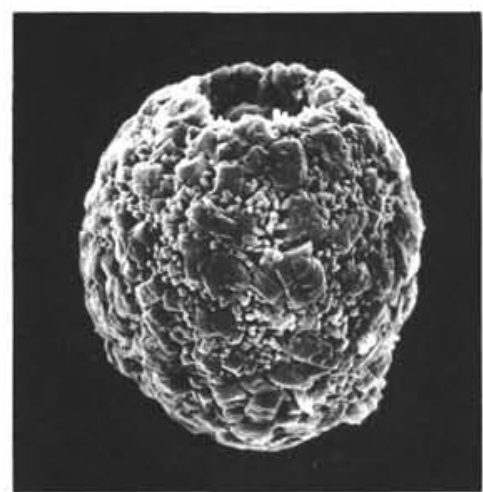

5

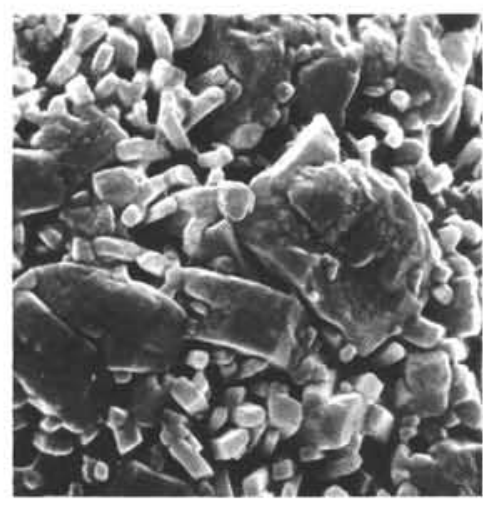

6

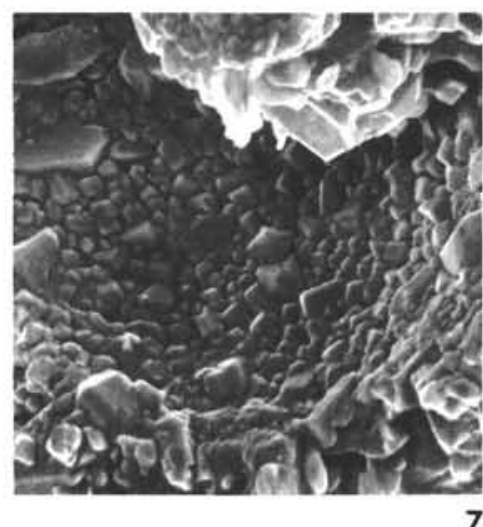

7

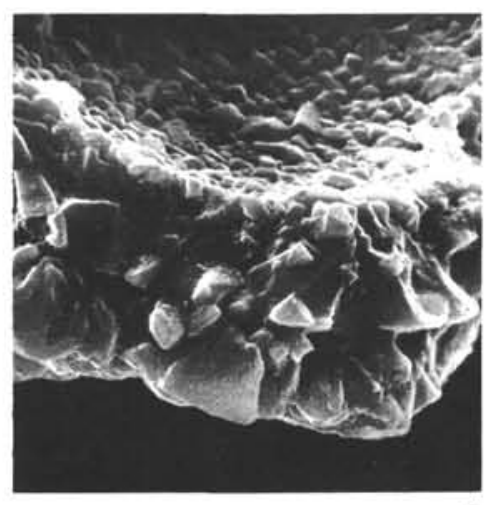

8

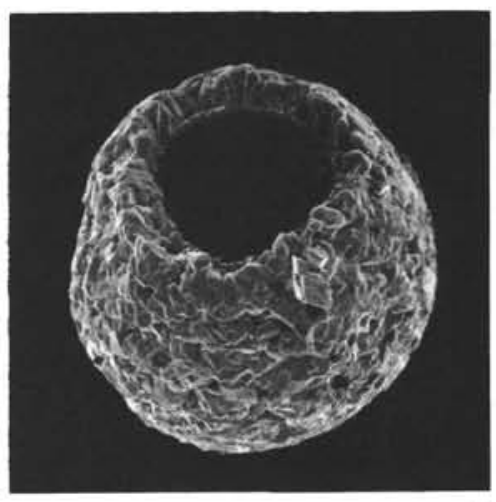

9

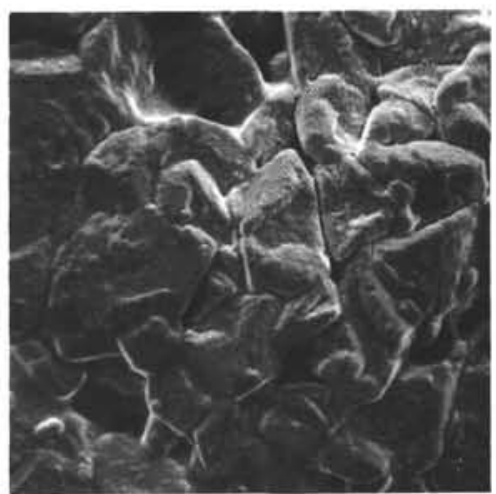

10
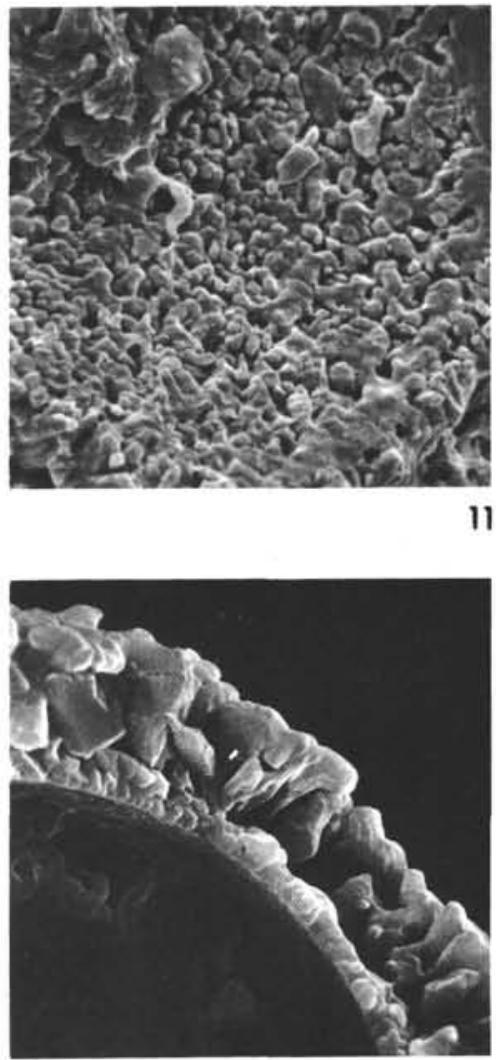

12 


\section{PLATE 5}

Figures 1-4 Pithonella francadecimae, Sample 259-12-2, 60-62 $\mathrm{cm}$.

1. Side view of holotype, $\times 650$, C 29885 .

2. Outer surface of holotype, $\times 2500, \mathrm{C} 29885$.

3. Inner surface of paratype, $\times 2500$, C 29886 .

4. Cross-section of paratype, $\times 2500$, C 29887.

Figures 5-8 Pithonella heirtzleri holotype from Sample 259-122, 60-62 cm, paratypes from Sample 259-13-2, 60$62 \mathrm{~cm}$.

5. Side/apertural view of holotype, $\times 750, \mathrm{C}$ 29891 ,

6. Outer surface of paratype, $\times 2500$, C 29892.

7. Inner surface of paratype, $\times 2500$, C 29893.

8 . Cross section of paratype, $\times 2500$, C 29893.

Figures 9-12 Pithonella veeversi, Sample 259-13-2, 60-62 cm.

9. Side view of holotype, $\times 500$, C 29898.

10. Outer surface of holotype, $\times 2500$, C 29898.

11. Inner surface of paratype, $\times 2500$, C 29899.

12. Cross section of paratype, $\times 2500$, C 29899. 
PLATE 5
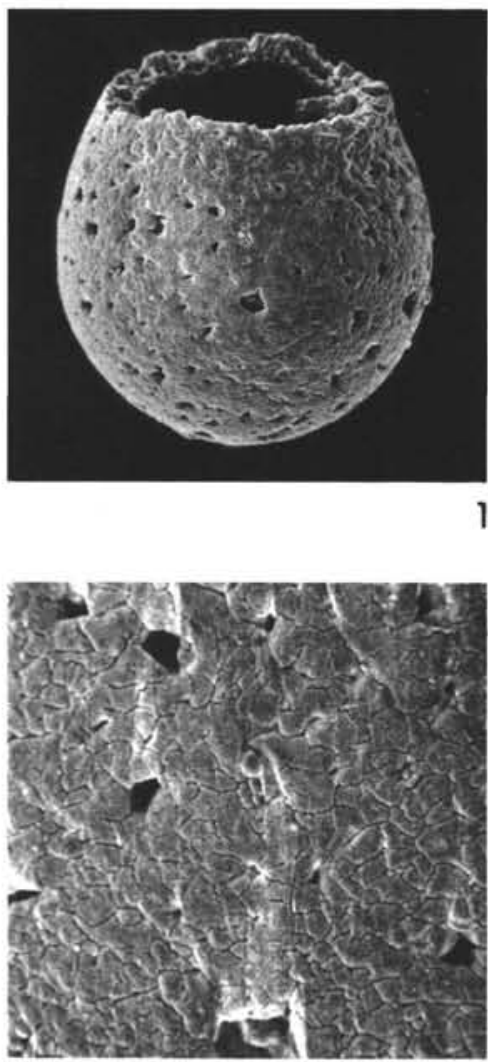

2
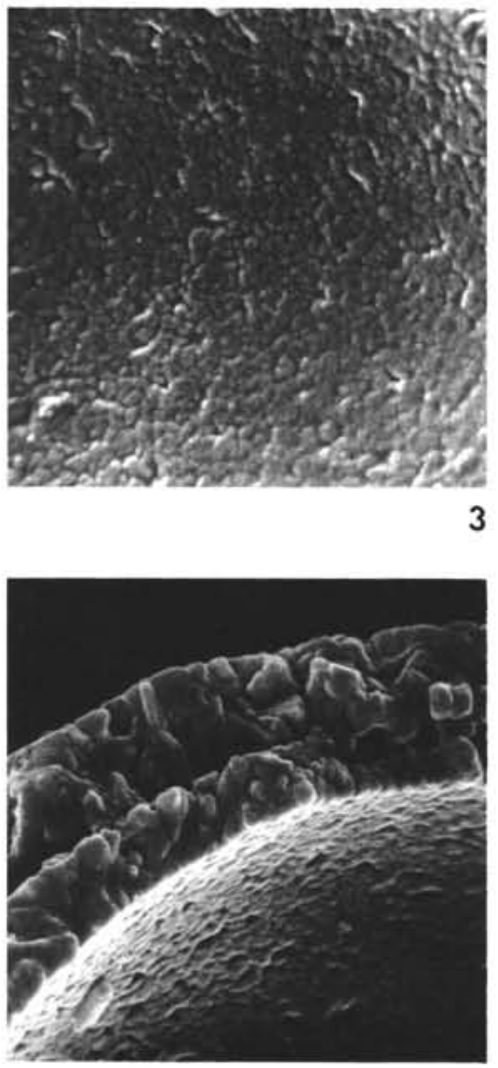

4
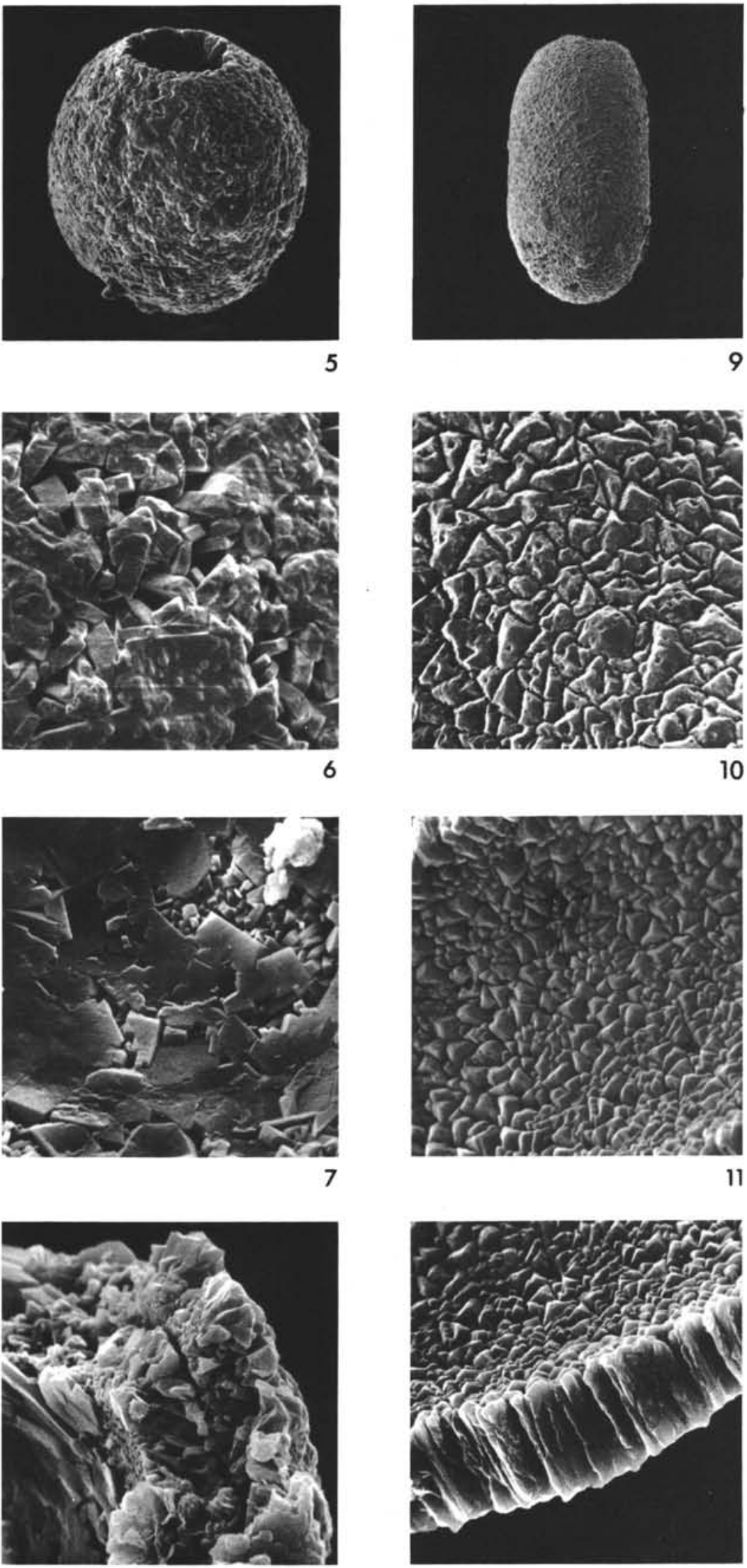

8 


\section{PLATE 6}

Figures 1-4 Pithonella quiltyi, Site 259.

1. Side/apertural view of holotype, $\times 550, C$ 29901.

2. Outer surface of paratype, Sample 12-2, 60-62 $\mathrm{cm}, \times 2500$, C 29902.

3. Inner surface of paratype, Sample 12-2, 60-62 $\mathrm{cm}, \times 2500$, C 29903.

4. Cross-section of paratype, Sample 13-2, 60-62 $\mathrm{cm}, \times 2500$, C 29904.

Figures 5-8 Pithonella johnstonei, Sample 260-6-1, 46-48 cm. 5 . Side/apertural view of holotype, $\times 800, C$ 29912.

6. Outer surface of holotype, $\times 2500$, C 29912.

7. Inner surface of paratype, $\times 2500, C 29913$.

8. Cross section of paratype, $\times 2500$, C 29913.

Figures 9-12 Pithonella cooki, Sample 260-6-1, 46-48 cm.

9. Side/apertural view of holotype, $\times 500, C$ 29914.

10. Outer surface of paratype, $\times 2500$, C 29915 .

11. Inner surface of paratype, $\times 2500, C 29916$.

12. Cross section of paratype, $\times 2500$, C 29916. 
PLATE 6

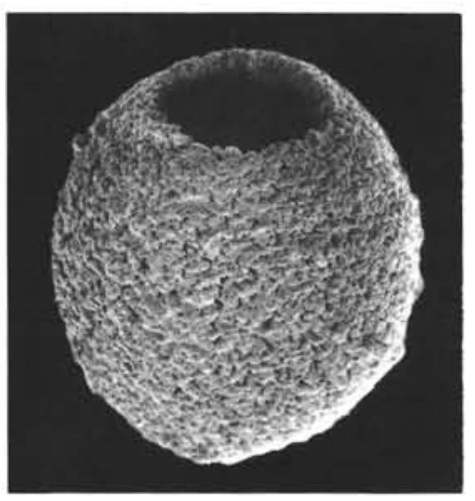

1
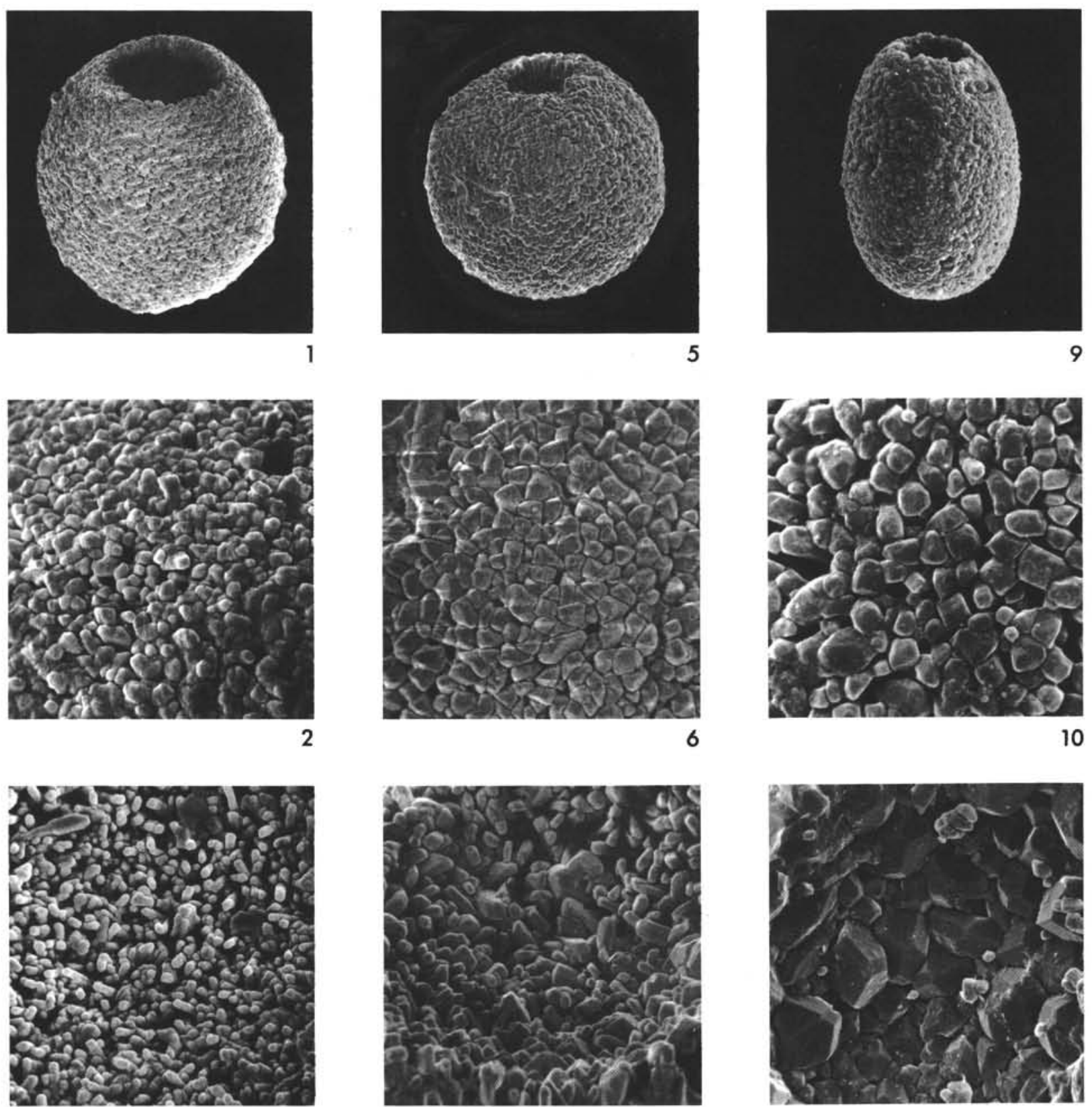

6
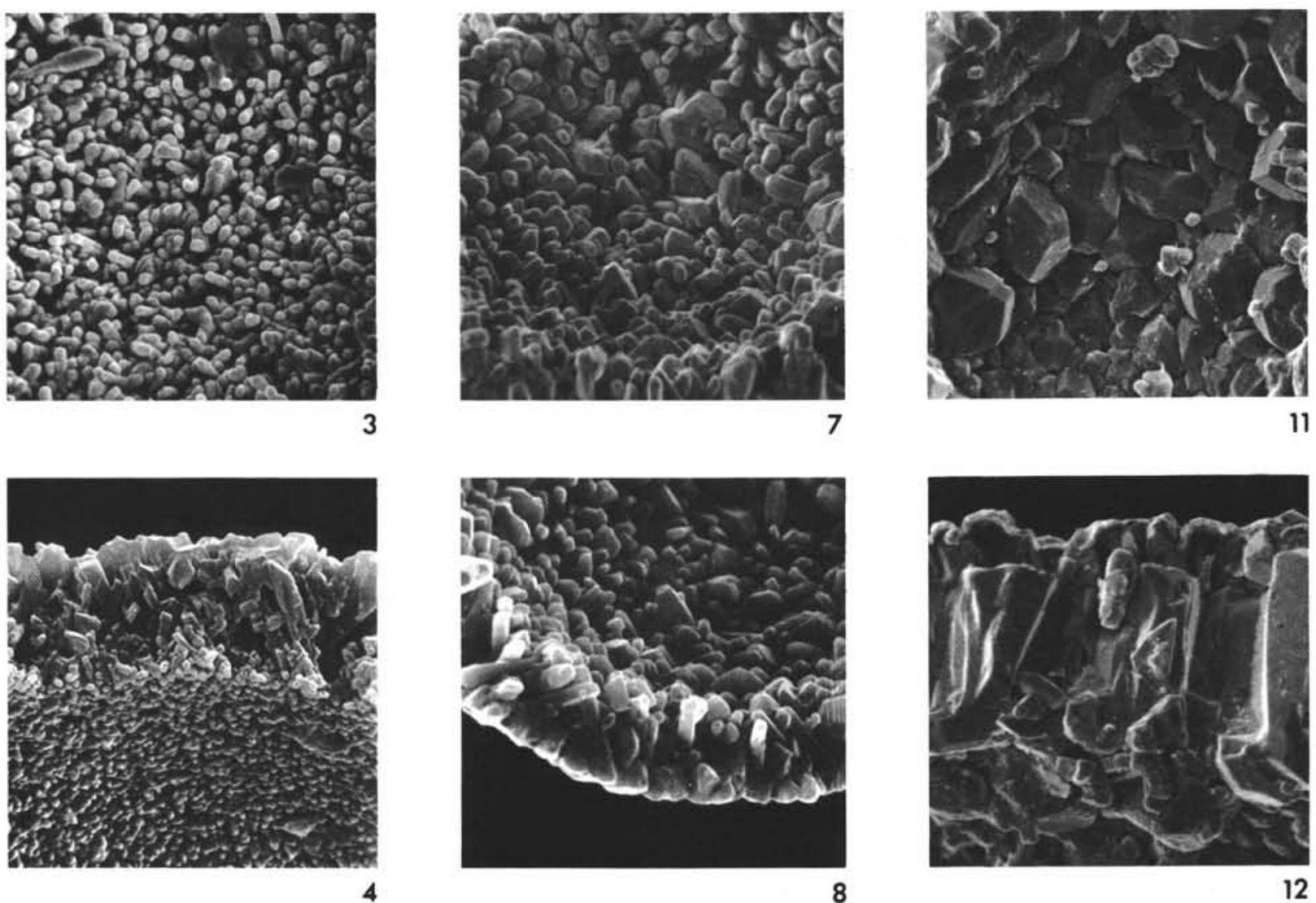


\section{PLATE 7}

Figures 1-5 Pithonella krasheninnikovi, Sample 260-6-1, 46-48 $\mathrm{cm}$.

1. Side/apertural view of holotype, $\times 350, \mathrm{C}$ 29921.

2. Outer surface of holotype, $\times 2500$, C 29921.

3. Outer surface of inner layer of paratype, $\times 2500$, C 29922 .

4. Inner surface of paratype, $\times 2500$, C 29923.

5. Cross-section of paratype, $\times 2500$, C 29923.

Figures 6-8 Pithonella $\mathrm{sp}$. B, Sample 260-6-1, 46-48 cm.

6. Side/apertural view, $\times 650$, C 29931.

7. Outer surface, $\times 2500, C 29931$.

8. Cross-section in aperture, $\times 2500$, C 29931.

Figures 9-12 Pithonella sp. A, Sample 263-3, CC.

9. Side view, $\times 650$, C 29932.

10. Outer surface, $\times 2500$, C 29932.

11. Inner surface, $\times 2500, C 29932$.

12. Cross-section in aperture, $\times 2500$, C 29932. 
PLATE 7
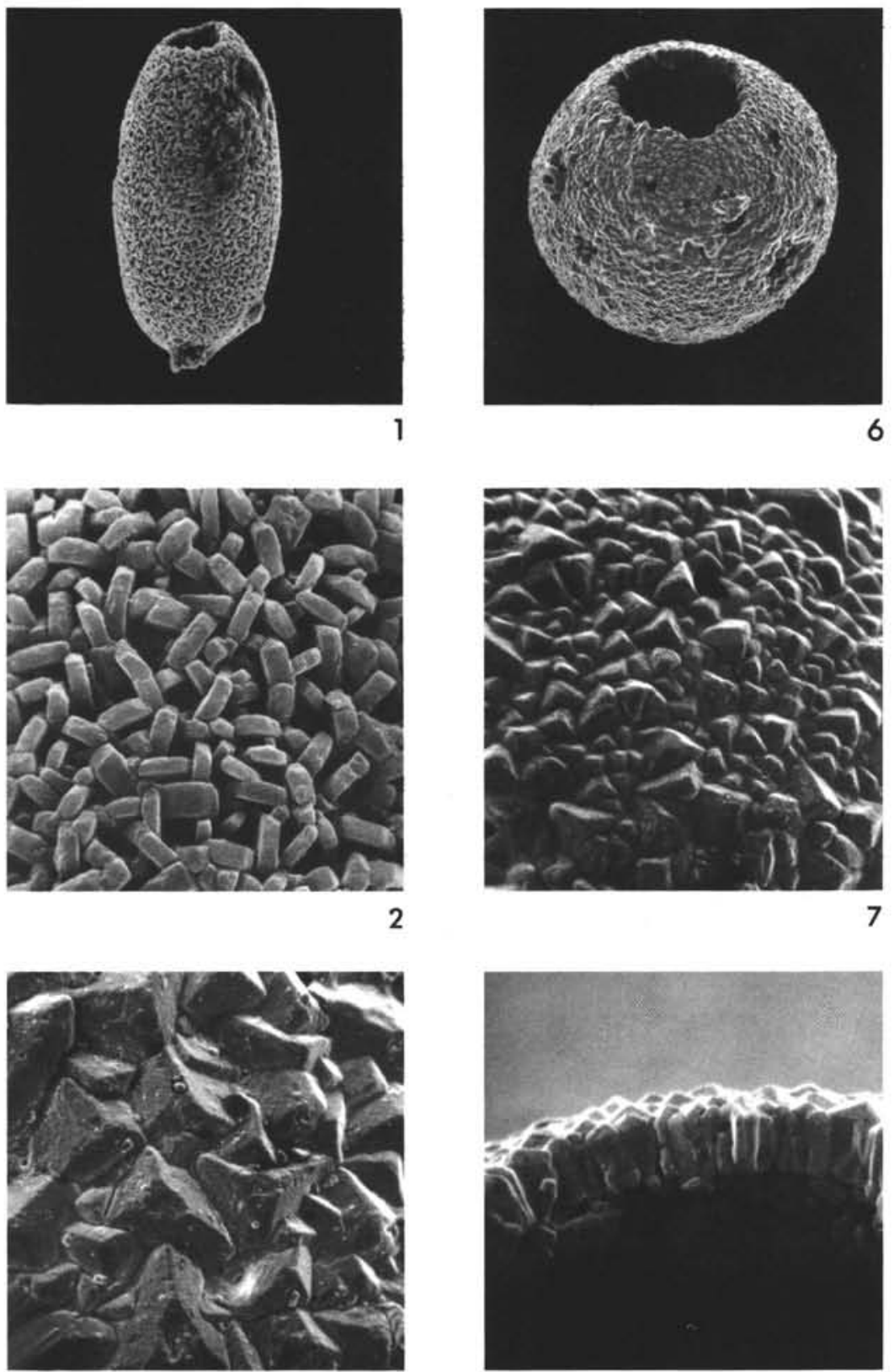

3

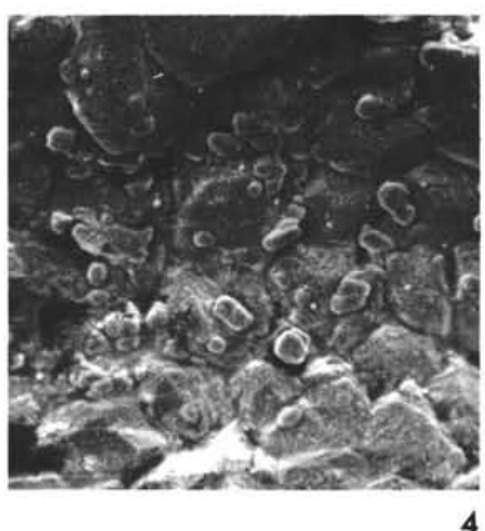

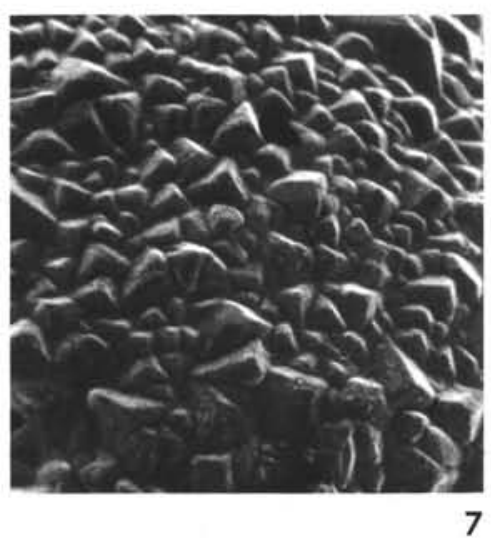
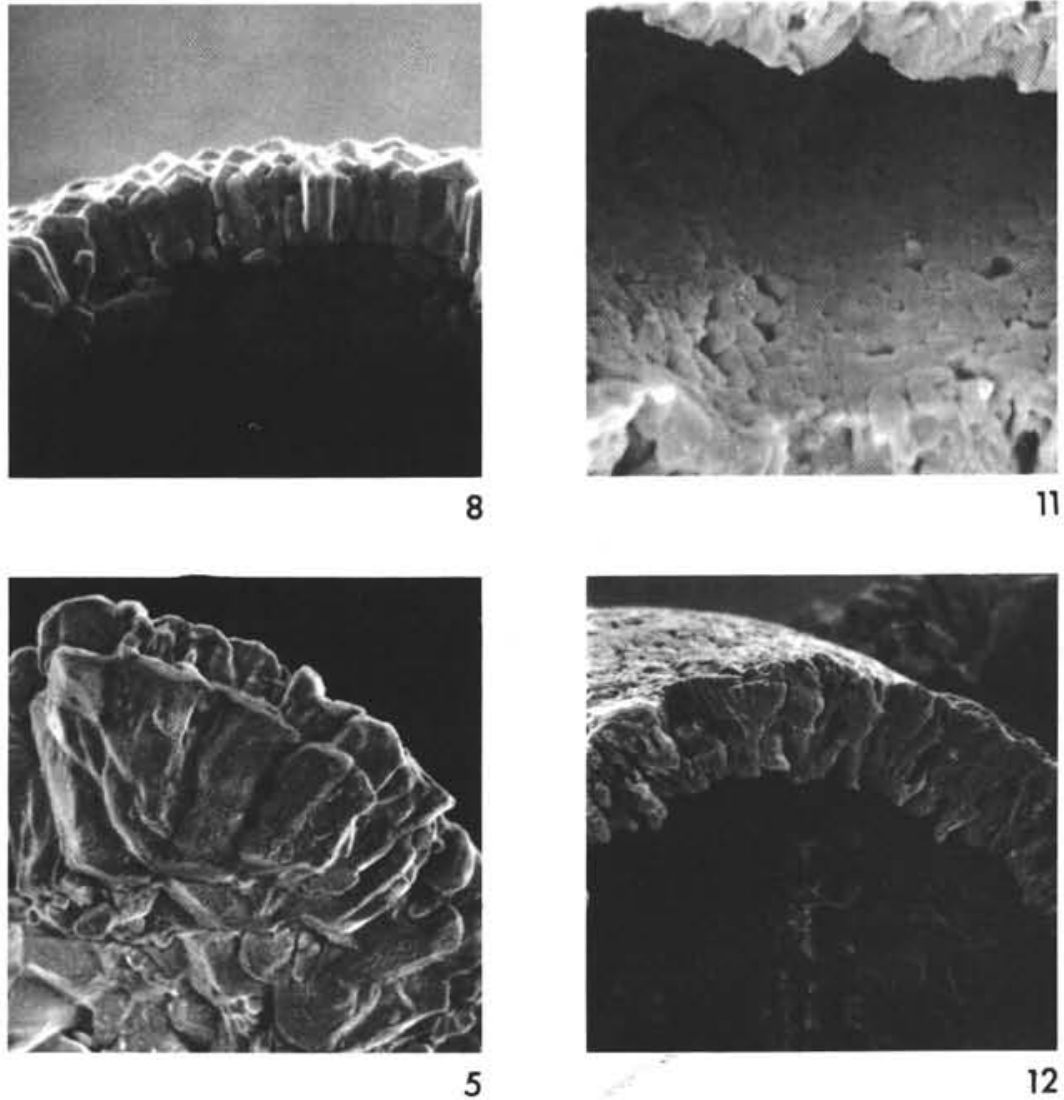
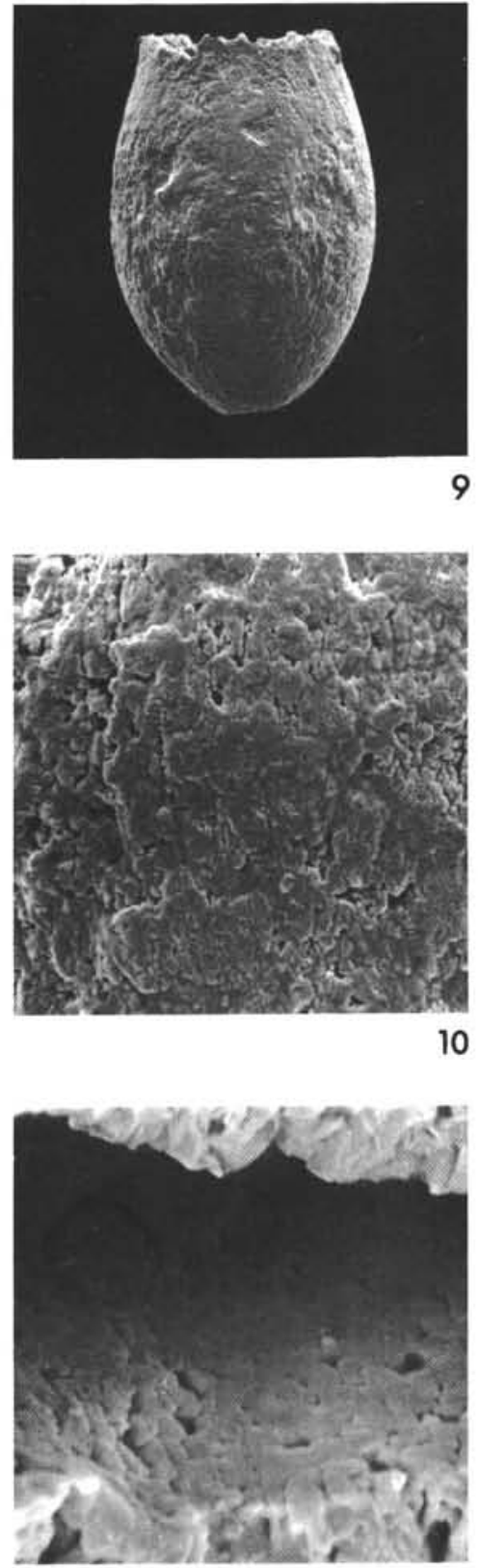

10

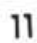




\section{PLATE 8}

Figures 1-3 Pithonella carteri, Sample 261-31, CC.

1. Paratype without aperture, $\times 700$, C 29812.

2. Paratype with fairly large, irregular aperture, $\times 750$, C 29813.

3. Cross-section of wall and inside view of broken paratype, $\times 900$, C 29811 .

Figures 4-8 Pithonella monighti, Sample 261-31, CC

4. Outer wall of holotype (Plate 1, Figure 5), $\times 1500$, C 29814 .

5 . Side/apertural view of paratype, $\times 750, C$ 29817.

6. Distal view of paratype, $\times 800, C 29818$.

7. Apertural view of paratype, $\times 1500$, C 29819.

8. Cross-section of wall and inside view of broken paratype, $\times 750$, C 29816 .

Figures 9-12 Pithonella thayeri, Site 261.

9. Spherical paratype without aperture, Sample

32, CC, $\times 700$, C 29824.

10. Spherical paratype formed by large crystals (detail see Plate 1, Figure 10), without aperture, Sample 31, CC, $\times 700$, C 29821.

11. Slightly irregular spherical paratype, without aperture, Sample 32, CC, ×700 C 29825.

12. Irregular spherical paratype, without aperture, Sample 31, CC, ×700, C 29826. 
PLATE 8
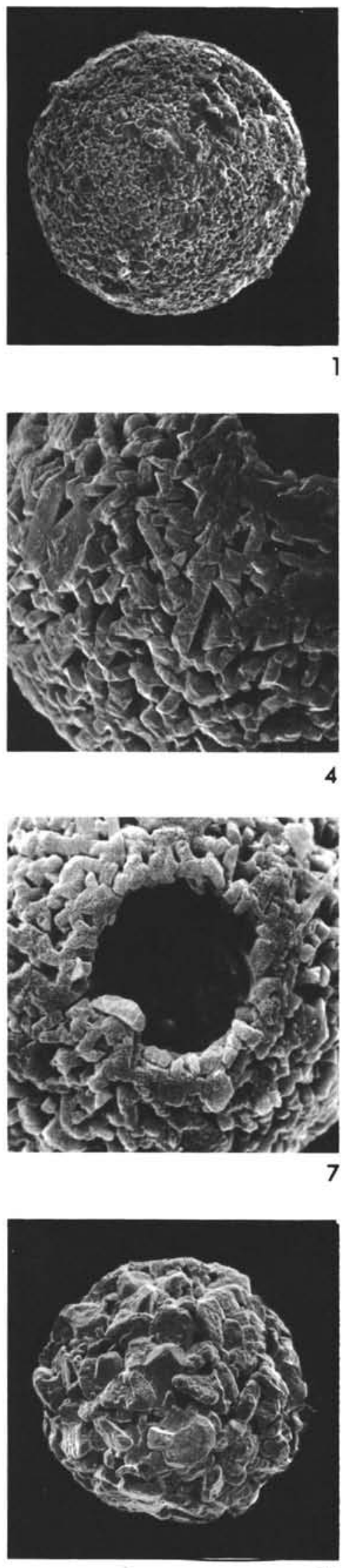
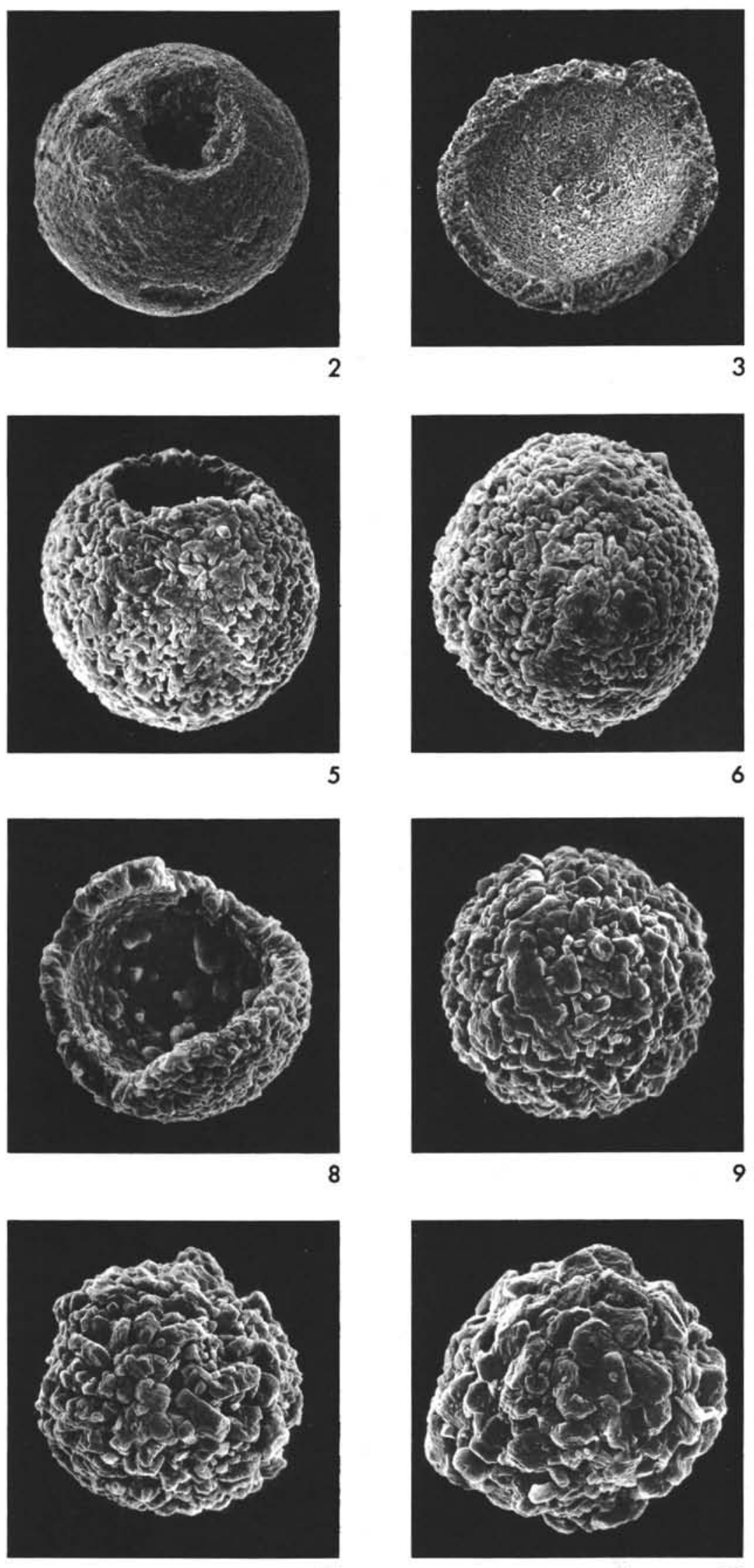

11 


\section{PLATE 9}

Figures 1-12 Pithonella thayeri, Site 261.

1. Irregular shaped paratype without aperture, Sample 33-1, 0-20 cm, ×500, C 29827.

2. Paratype with small aperture, Sample $32, \mathrm{CC}$, $\times 500$, C 29828.

3. Paratype with large aperture, Sample $32, \mathrm{CC}$, $\times 700$, C 29829.

4. Paratype with medium aperture, Sample 32, CC, $\times 600$, C 29830.

5. Wall surface in apertural area of paratype Figure 4, Sample 32, CC, ×1500, C 29830.

6. Paratype with very large aperture, inside of wall visible (? broken specimen), Sample 31, CC, $\times 700$, C 29822.

7. Cross-section of wall and inside view of broken paratype, Sample 32, CC, ×600, C 29823.

8. Broken paratype with thin inner layer, Sample 33-1, $0-20 \mathrm{~cm} \times 500$, C 29831.

9. Wall cross-section of paratype Figure 8, Sample 33-1, 0-20 cm $\times 1500$, C 29831.

10. Paratype consisting of two in apertural area closely attached specimens, Sample 33-1, 0-20cm, $\times 350$, C 29832.

11. Detail of attachment in paratype Figure 10, Sample 33-1, 0-20 cm, ×1000, C 29832.

12. Paratype consisting of two in apertural area closely attached specimens, Sample 33-1, 0-20 cm $\times 350$, C 29833. 
PLAte 9

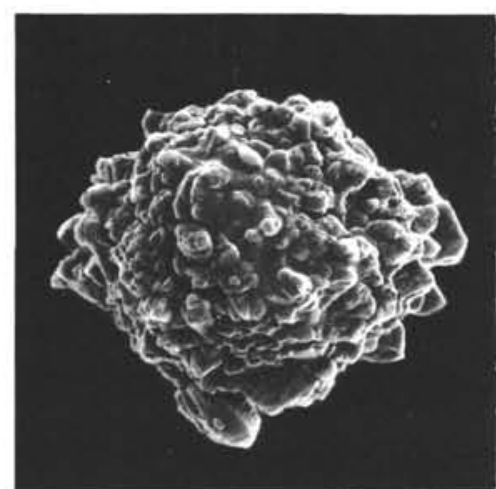

1

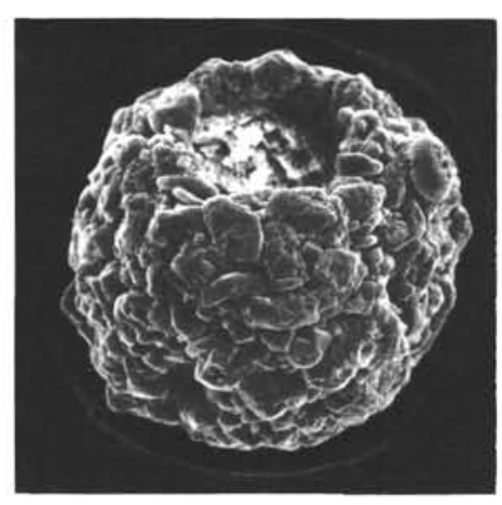

4

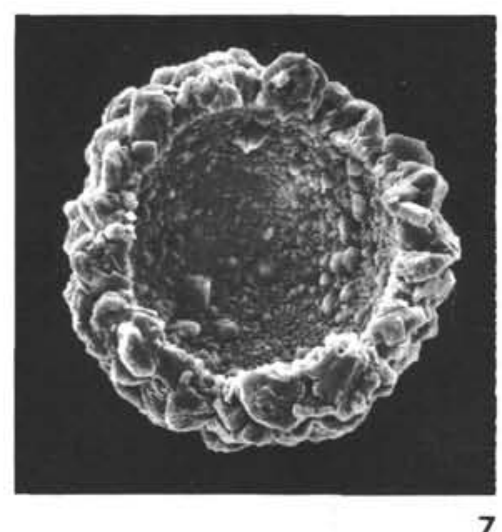

7

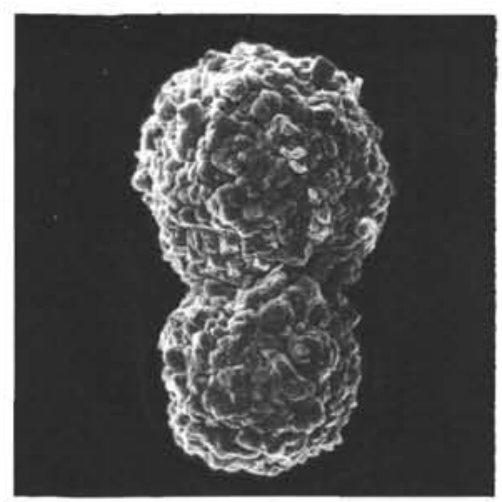

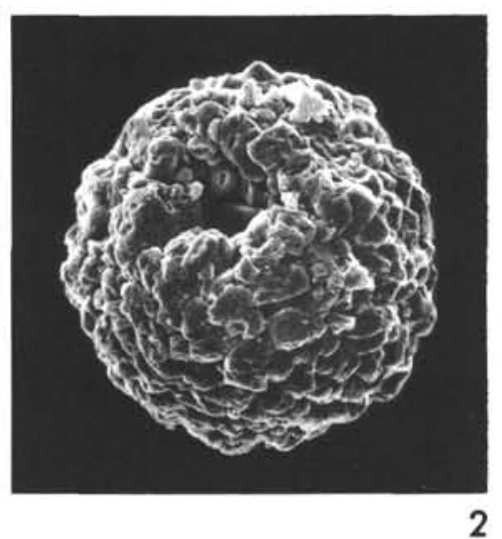
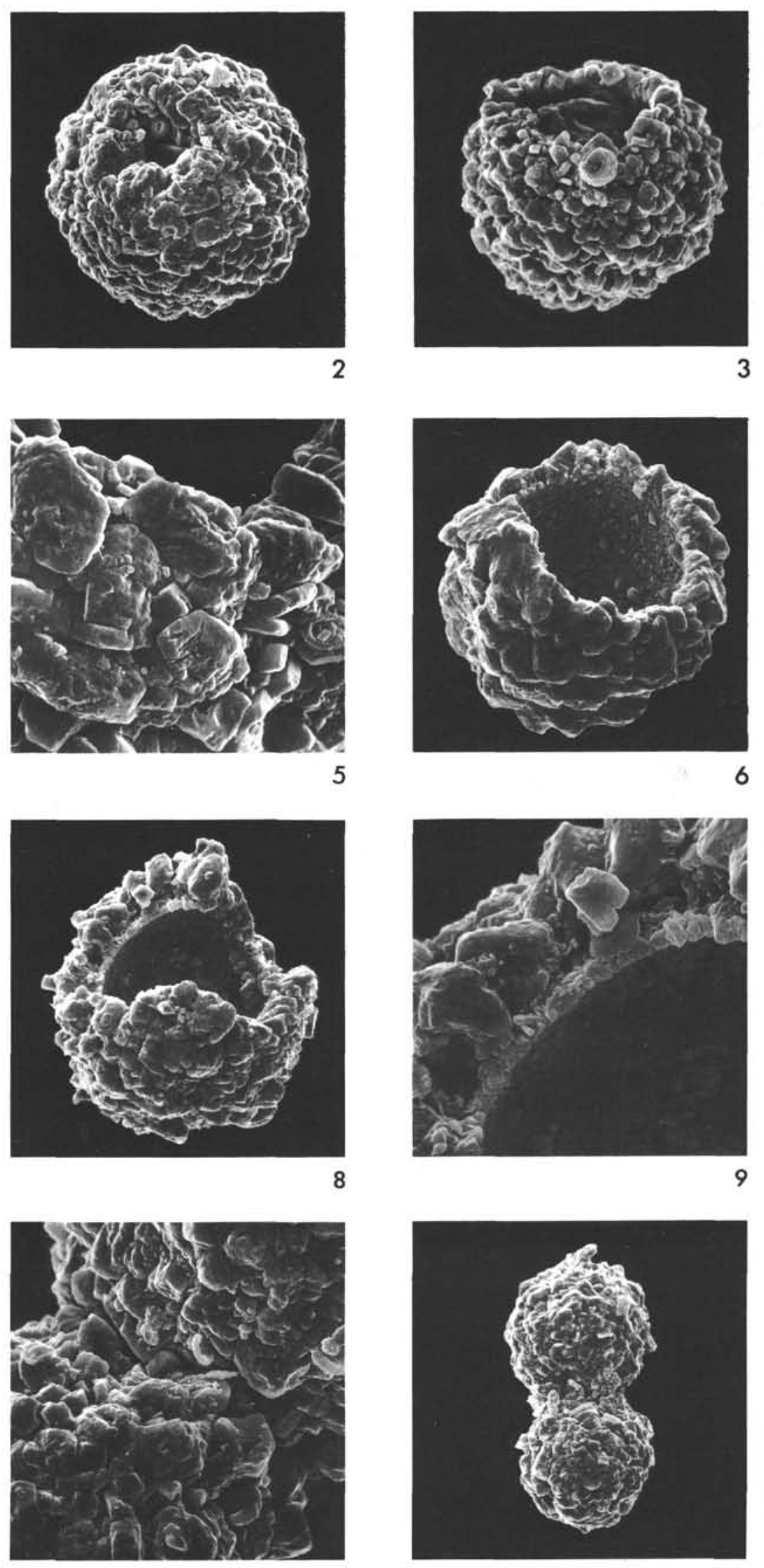

11 


\section{PLATE 10}

Figures 1-8 Pithonella helentappane, Sample 263-17, CC.

1. Distal view of paratype, $\times 700, C 29835$.

2. Wall surface in apertural area of paratype, $\times 1500$, C 29834 .

3. Apertural view of paratype with small aperture, $\times 600$, C 29838.

4. Apertural view of paratype with large aperture, $\times 600$, C 29839.

5. Apertural area of paratype Figure $4, \times 1500, C$ 29839.

6. Cross-section of wall and inside view of broken specimen, $\times 600$, C 29837.

7. Paratype formed by well-developed and preserved crystals, $\times 600$, C 29840.

8. Wall surface of paratype Figure 7, ×1500, C 29840.

Figures 9-12 Pithonella nonarenzae, Sample 263-17, CC.

9. Paratype, slightly elongate/irregular, without aperture, $\times 700$, C 29845.

10. Side/apertural view of paratype, $\times 650, C$ 29846.

11. Paratype, without aperture, $\times 700$, C 29847.

12. Cross section of wall and inside view of broken specimen, $\times 800$, C 29844. 
PLATE 10
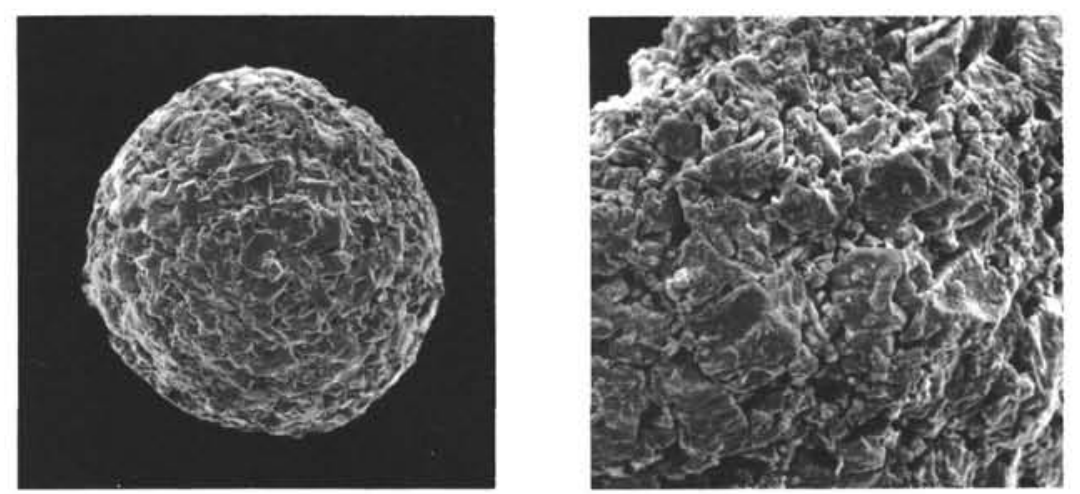

2

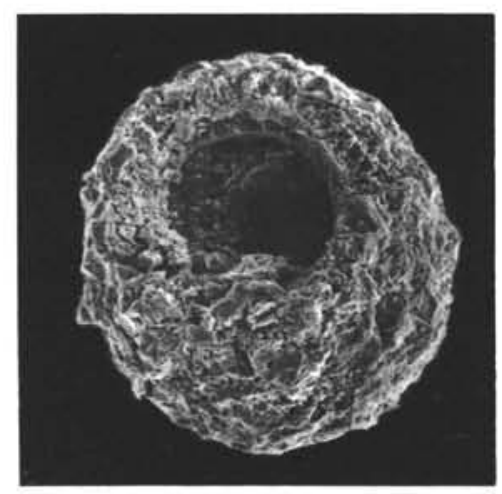

4
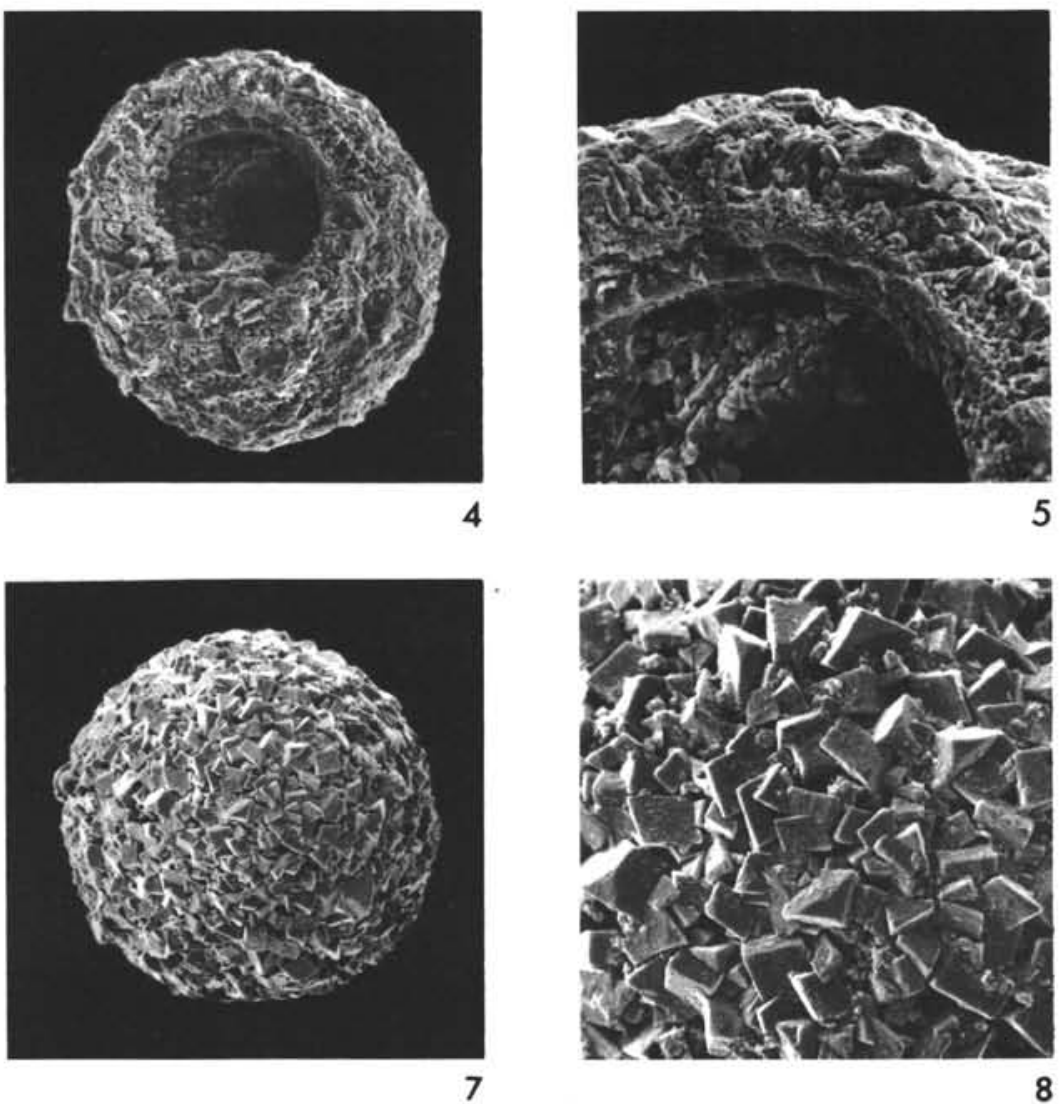

5
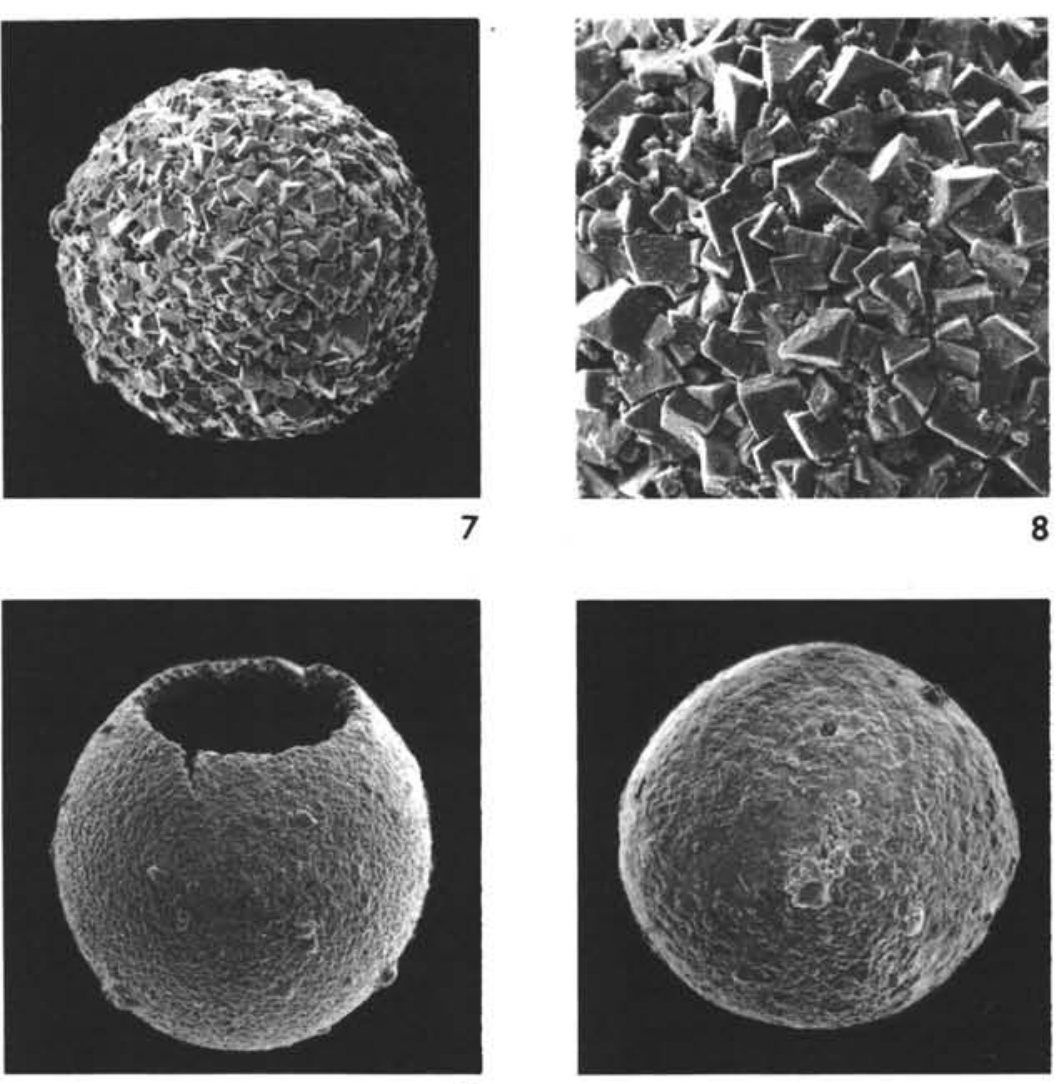

11
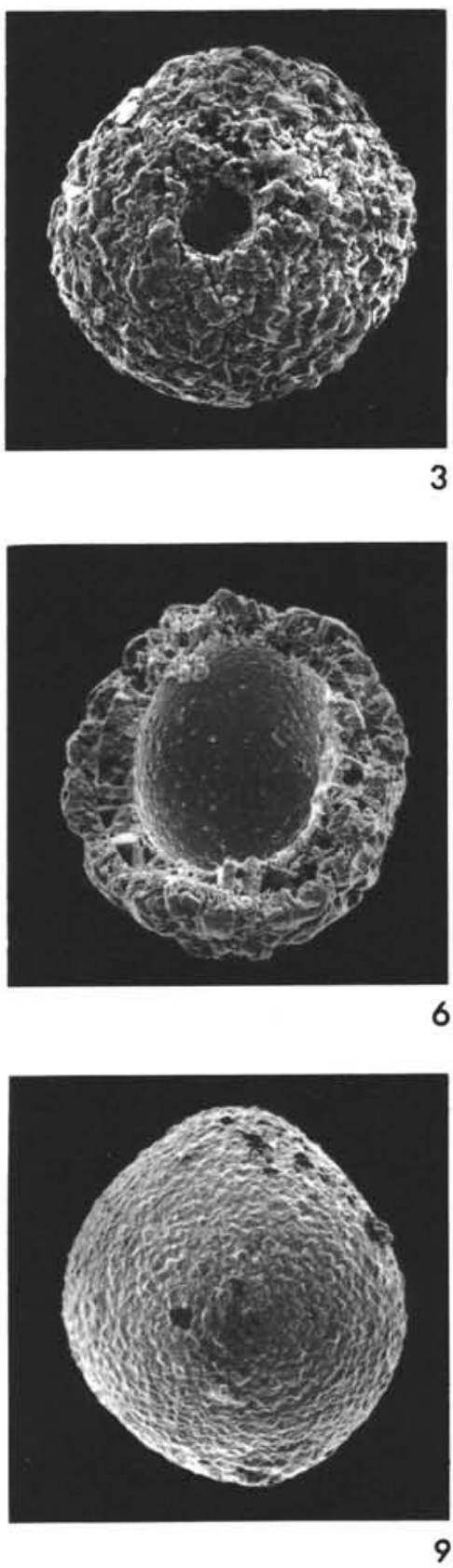

6

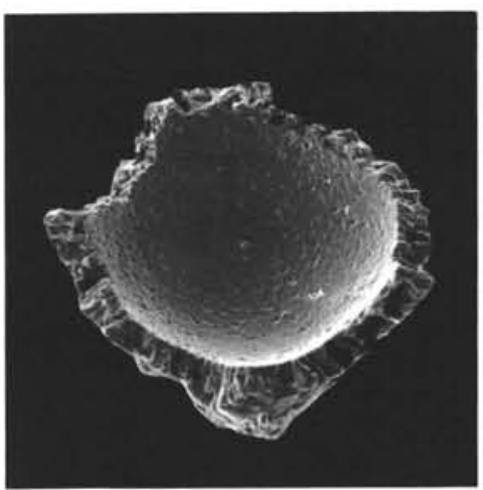




\section{PLATE 11}

Figures 1-8 Pithonella patriciagreeleyae, Site 263.

1. Paratype with very smooth surface and without aperture, Sample 3, CC, $\times 800$, C 29850.

2. Wall surface of paratype Figure 2, Sample 3, CC, $\times 2500$, C 29850 .

3. Side view of paratype, smooth surface with some angular pits, large aperture, Sample 5, CC, $\times 750$, C 29851 .

4. Wall surface of paratype Figure 3, Sample 5, CC, $\times 2500$, C 29851.

5. Paratype showing distinct crystals, no aperture, Sample 3, CC, $\times 800$, C 29852.

6. Wall surface of paratype Figure 3, Sample 3, CC, $\times 2500$, C 29852.

7. Broken paratype with sphere of unknown origin inside, Sample 3, CC, ×700, C 29853.

8. Cross section of wall and inside view of broken paratype, Sample 3, CC, ×750, C 29849.

Figures 9-12 Pithonella loeblichi, Sample 260-15, CC.

9. Side view of holotype, $\times 650, C 29854$.

10. Apertural area of holotype, $\times 1000$, C 29854.

11. Side/apertural view of paratype, $\times 700, C$ 29857.

12. Apertural area of paratype Figure $11, \times 2000$, C 29857. 
PLATE 11
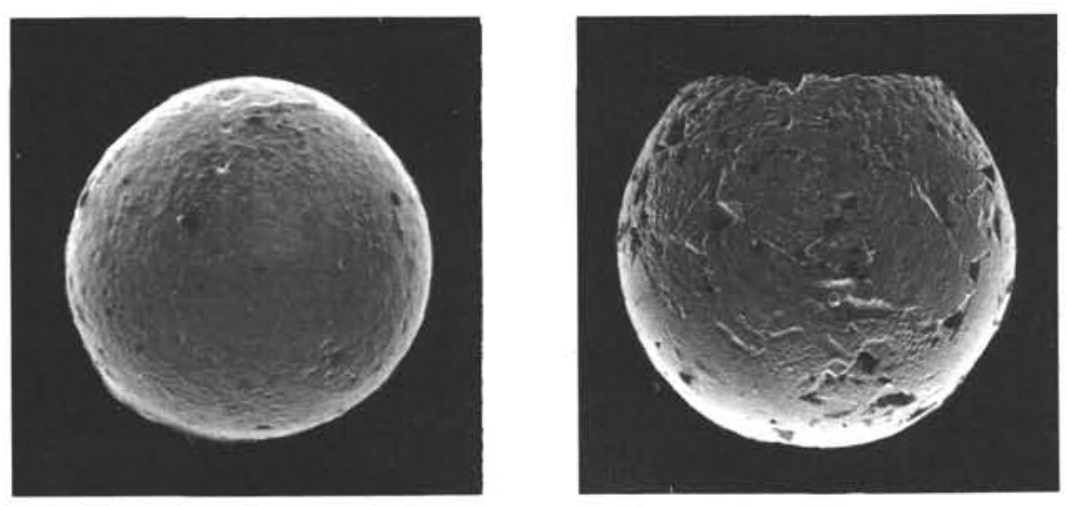

3
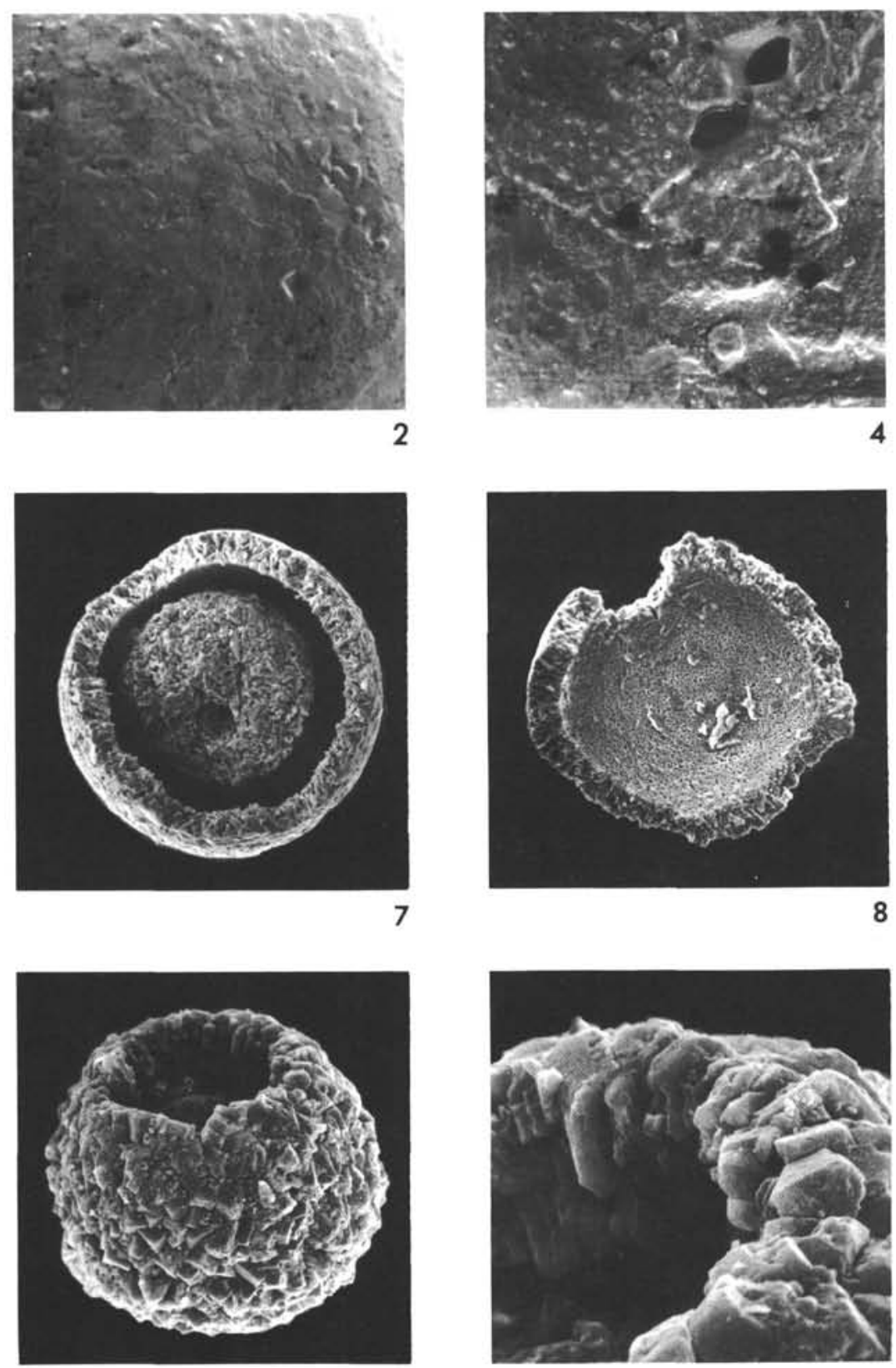

11

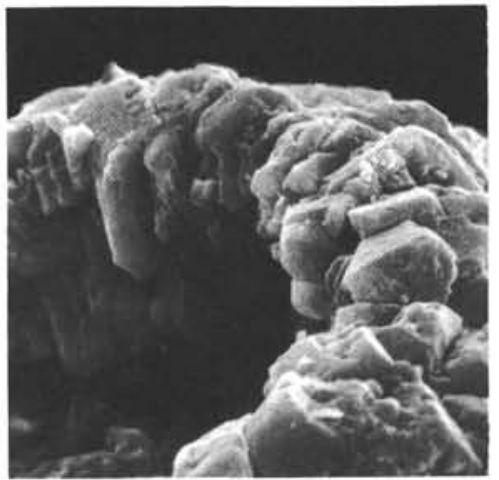

12
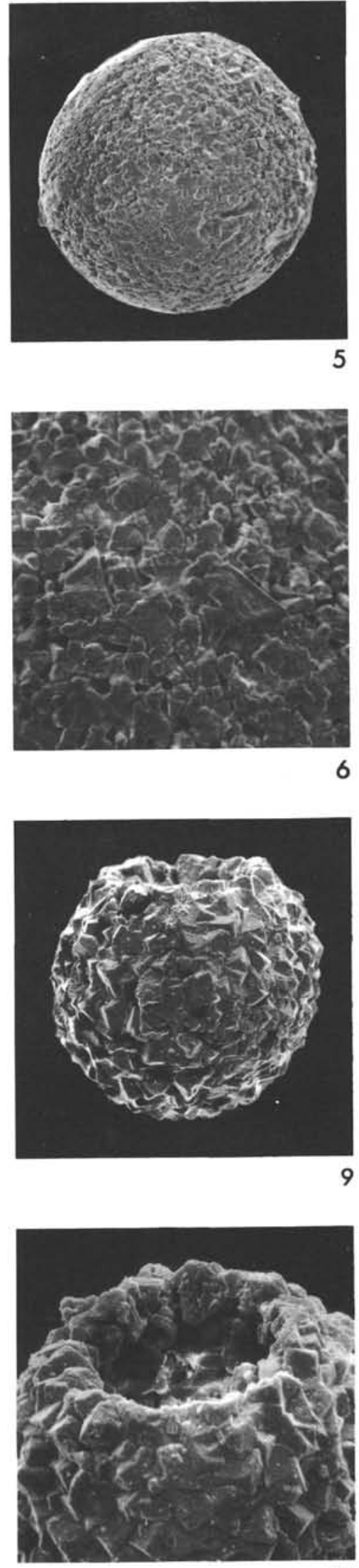

10 


\section{PLATE 12}

Figures 1-3 Pithonella loeblichi, Sample 260-15, CC.

1. Apertural view of paratype, $\times 650, C 29858$.

2. Apertural area of paratype Figure $1, \times 1100, \mathrm{C}$ 29858.

3. Cross-section of wall and inside view of broken paratype, $\times 700$, C 29855 .

Figures 4-6 Pithonella rockeri, Sample 260-12-1, 86-88 cm.

4. Distal view of paratype, $\times 700, C 29860$.

5. Surface detail of paratype Figure $4, \times 1500, C$ 29860.

6. Cross-section of wall and inside view of broken paratype, $\times 1000$, C 29861 .

Figures 7-12 Pithonella gustafsoni, Site 260.

7. Side/apertural view of paratype, part of wall around apertural rim broken out (upper part of photograph), exposing radially arranged crystals, Sample 11-1,100-102 cm, ×650, C 29866.

8. Side/apertural view of paratype with large aperture with smoothened rim, Sample 11-1, 100$102 \mathrm{~cm}, \times 650$, C 29864.

9. Apertural area of holotype (see Plate 3, Figure 9), Sample 9, CC, ×2500, C 29863.

10. Side view of paratype, Sample 11-1, 100-102 $\mathrm{cm}, \times 650, \mathrm{C} 29867$.

11. Surface detail of paratype Figure 10 (with Watznaueria sp.), Sample 11-1, 100-102 cm, $\times 2500$, C 29867.

12. Irregular shaped partly broken apertural area of paratype. Inside of specimen filled with coccolith and debris, Sample 11-1, 100-102 cm, $\times 1050$, C 29868 . 
PLATE 12

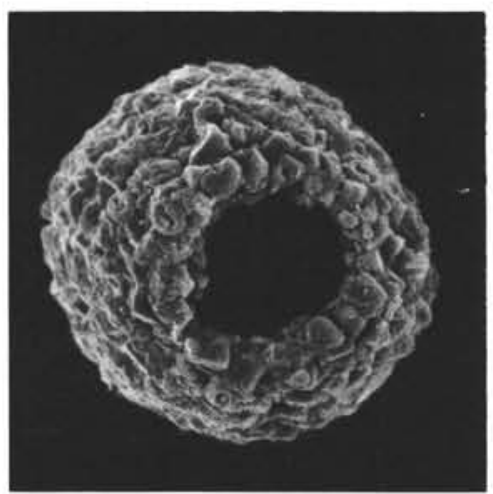

1
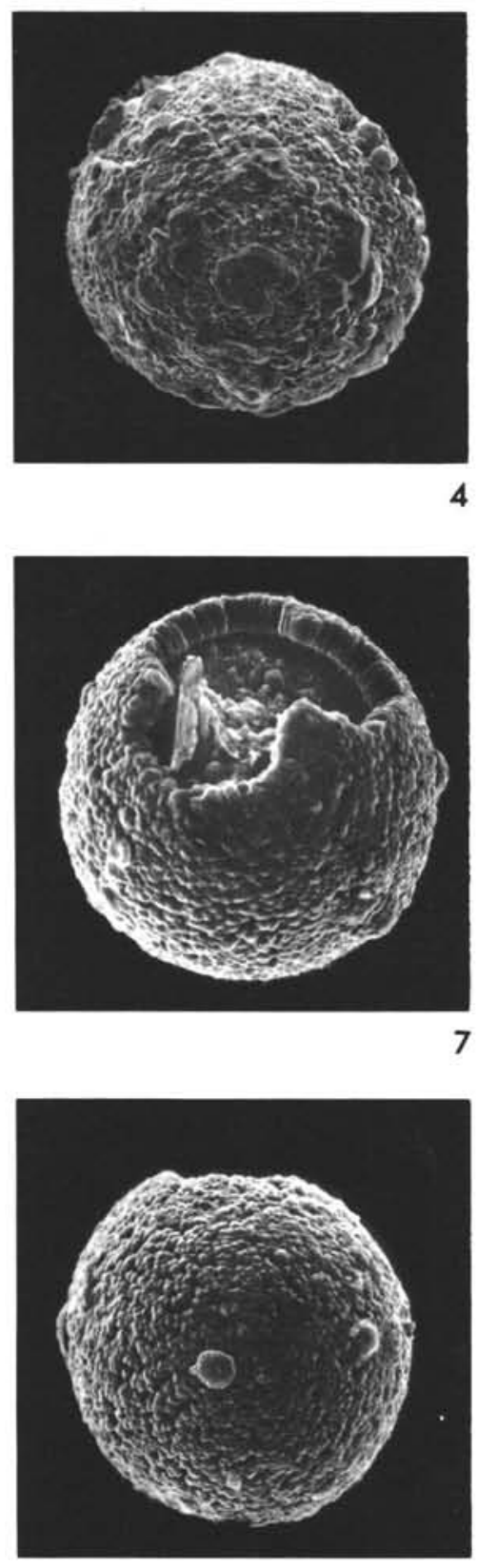

10

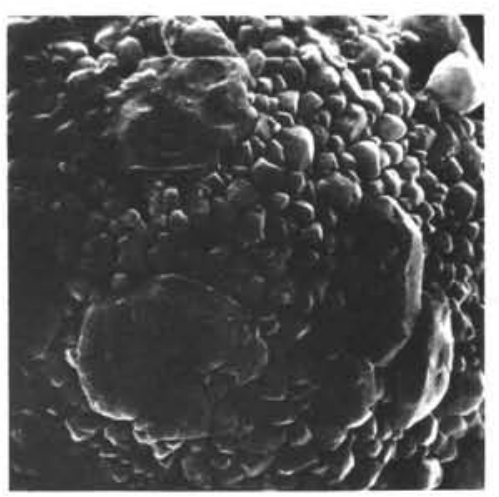

5

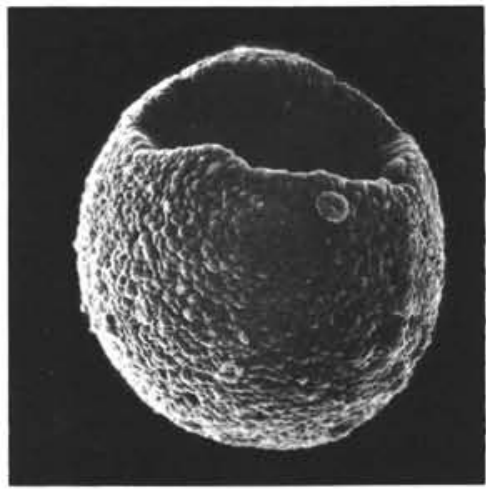

8
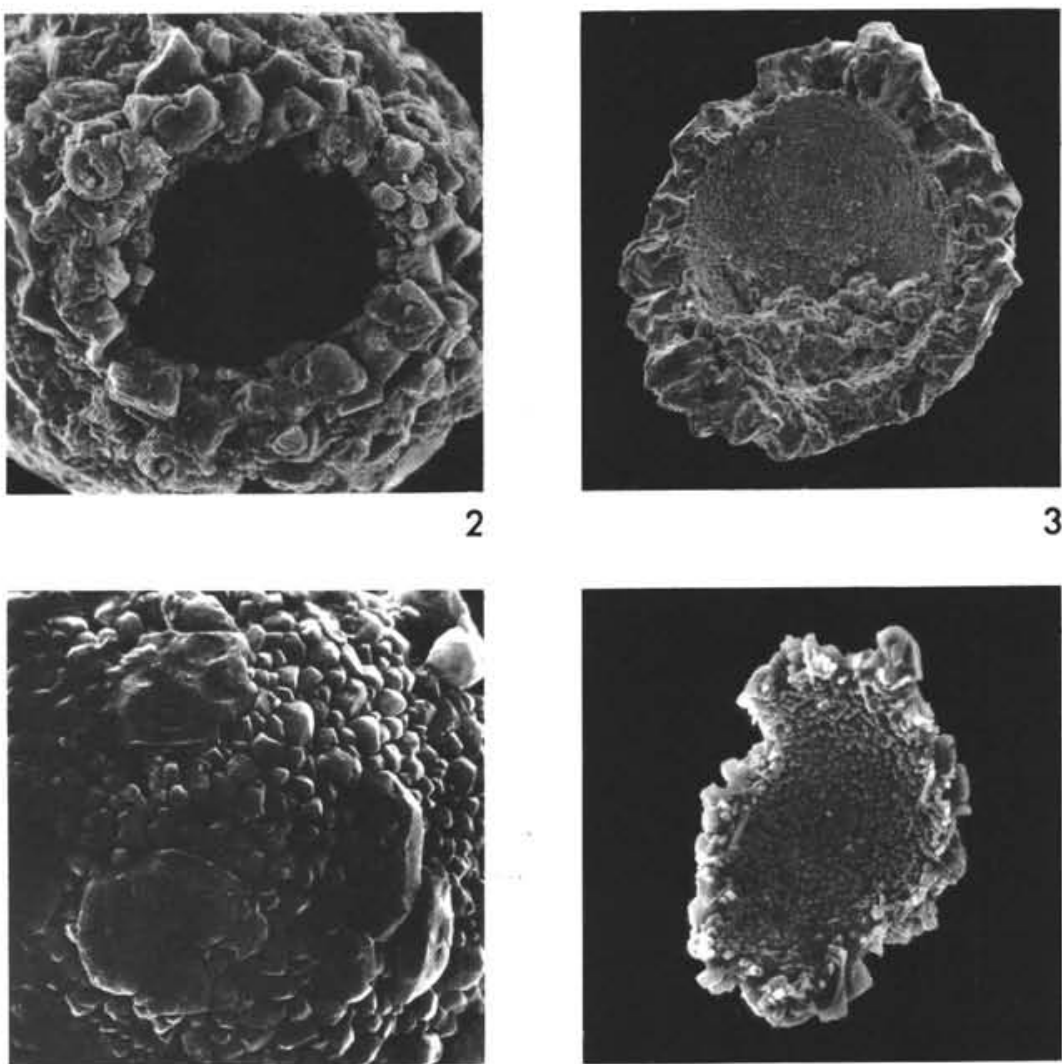

6
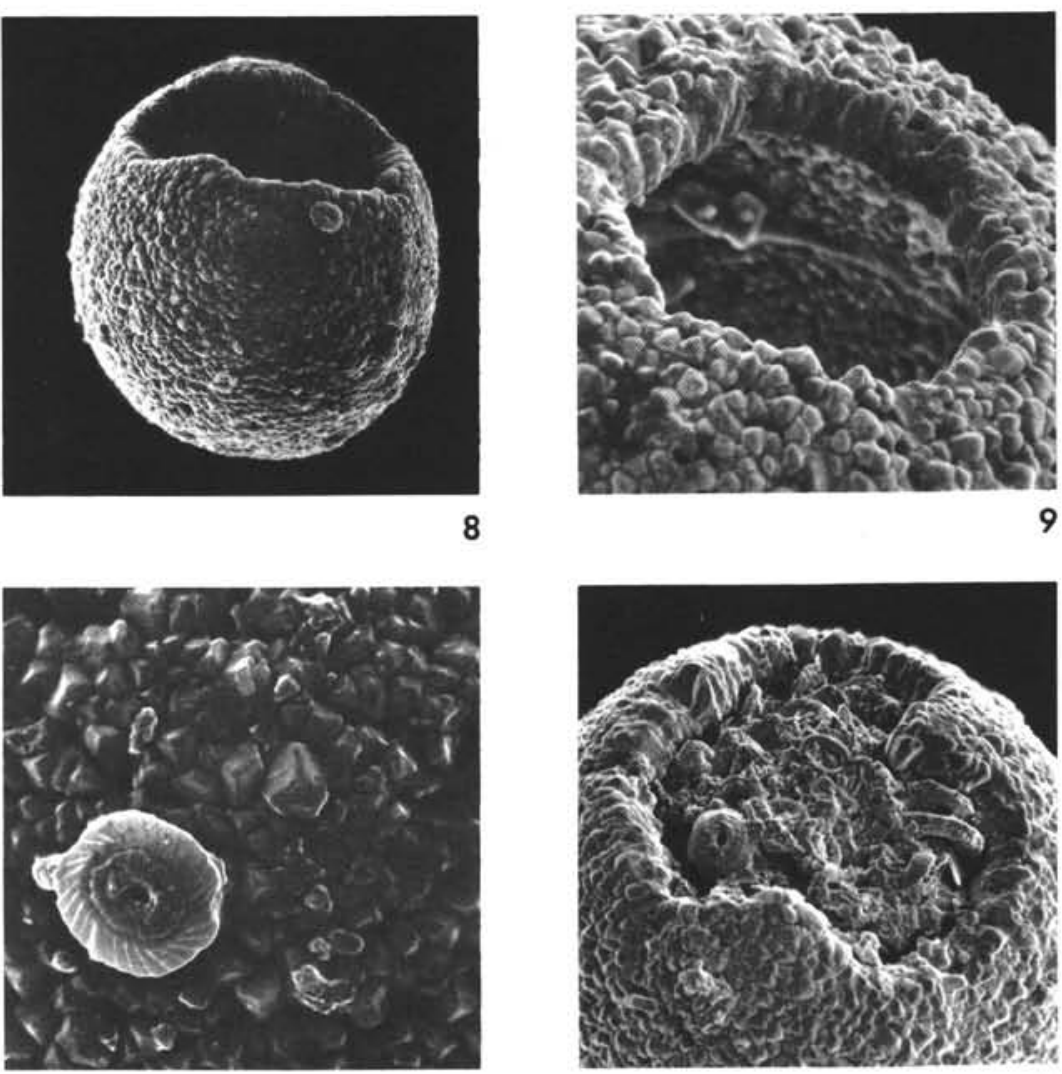

11 


\section{PLATE 13}

Figures 1-2 Pithonella gustafsoni, Sample 260-11-1, 100-102 $\mathrm{cm}$.

1. Cross section of wall and inside view of broken paratype, $\times 800$, C 29865.

2. Wall cross-section and inside surface of paratype, $\times 2500$, C 29869.

Figures 3-7 Pithonella edgari, Site 259.

3. Apertural area of holotype (see Plate 4, Figure

1), Sample $15-5,124-126 \mathrm{~cm}, \times 1500, \mathrm{C} 29870$.

4. Side view of paratype, Sample 13-2, 60-62 cm, $\times 800$, C 29872.

5. Paratype without aperture, Sample 13-2, 60-62 $\mathrm{cm}, \times 700$, C 29873.

6. Outer surface of paratype, Sample 13-2, 60-62 $\mathrm{cm}, \times 2500$, C 29874.

7. Cross section of wall and inside view of broken paratype, Sample 13-2, 60-62 cm, ×750, C 29871.

Figures 8-12 Pithonella robinsoni, Sample 259-17-2, 47-49 cm.

8. Apertural area of holotype, $\times 1500$, C 29875.

9. Apertural area of holotype, $\times 2500$, C 29875.

10. Side view of paratype, $\times 600, C 29877$.

11. Distal view of paratype, $\times 700, C 29878$.

12. Distal view of paratype Figure $11, \times 1500, C$ 29878 . 
Plate 13

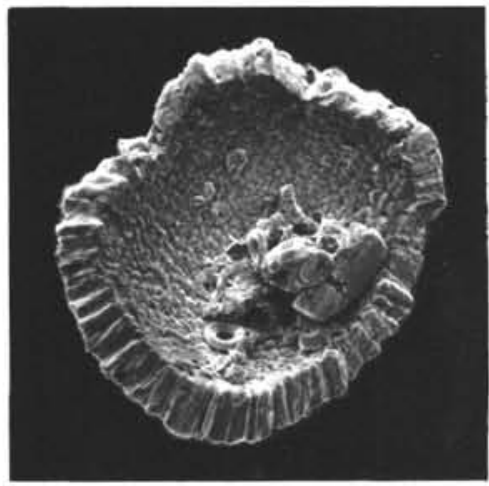

1

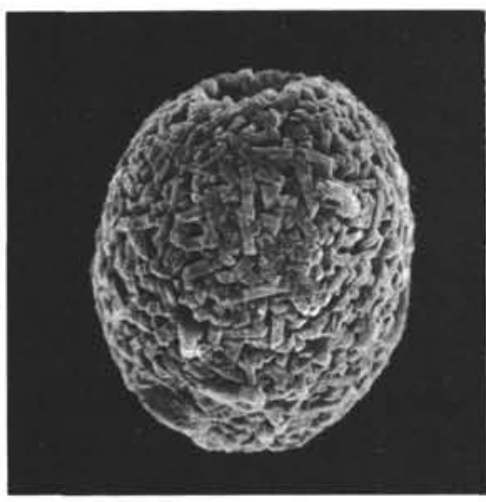

4
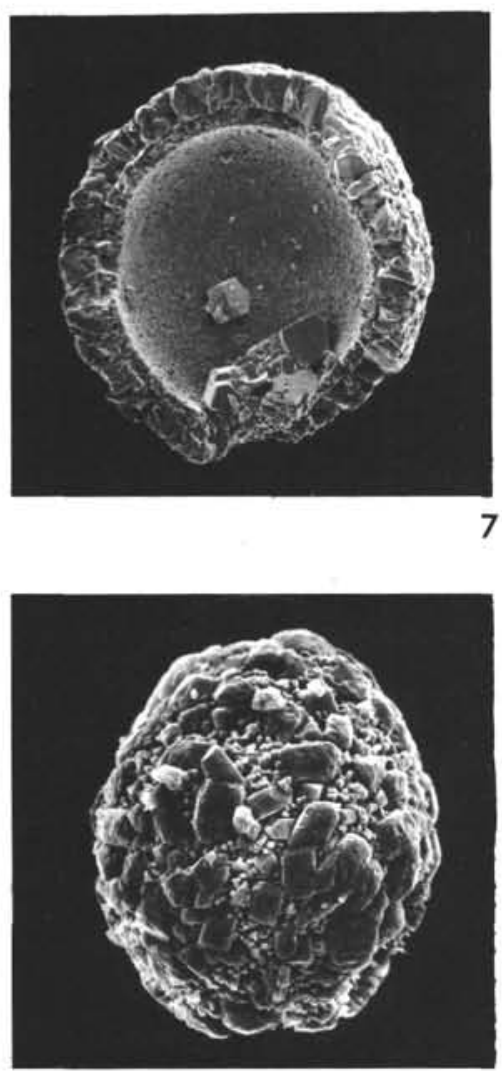

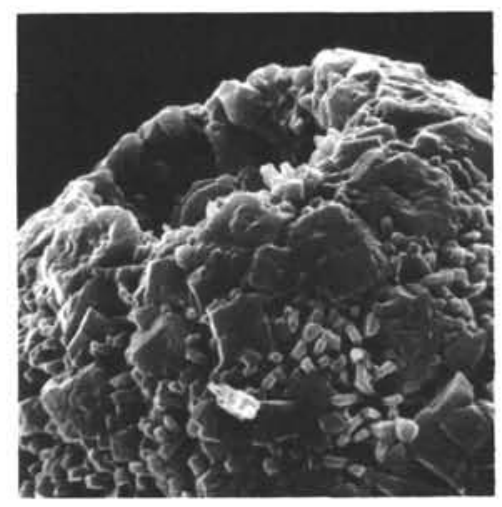

8
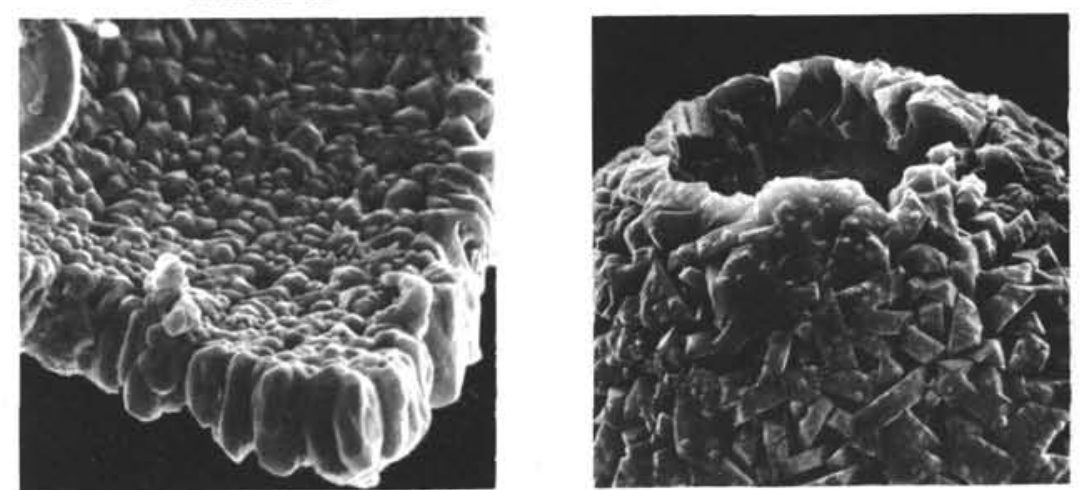

2
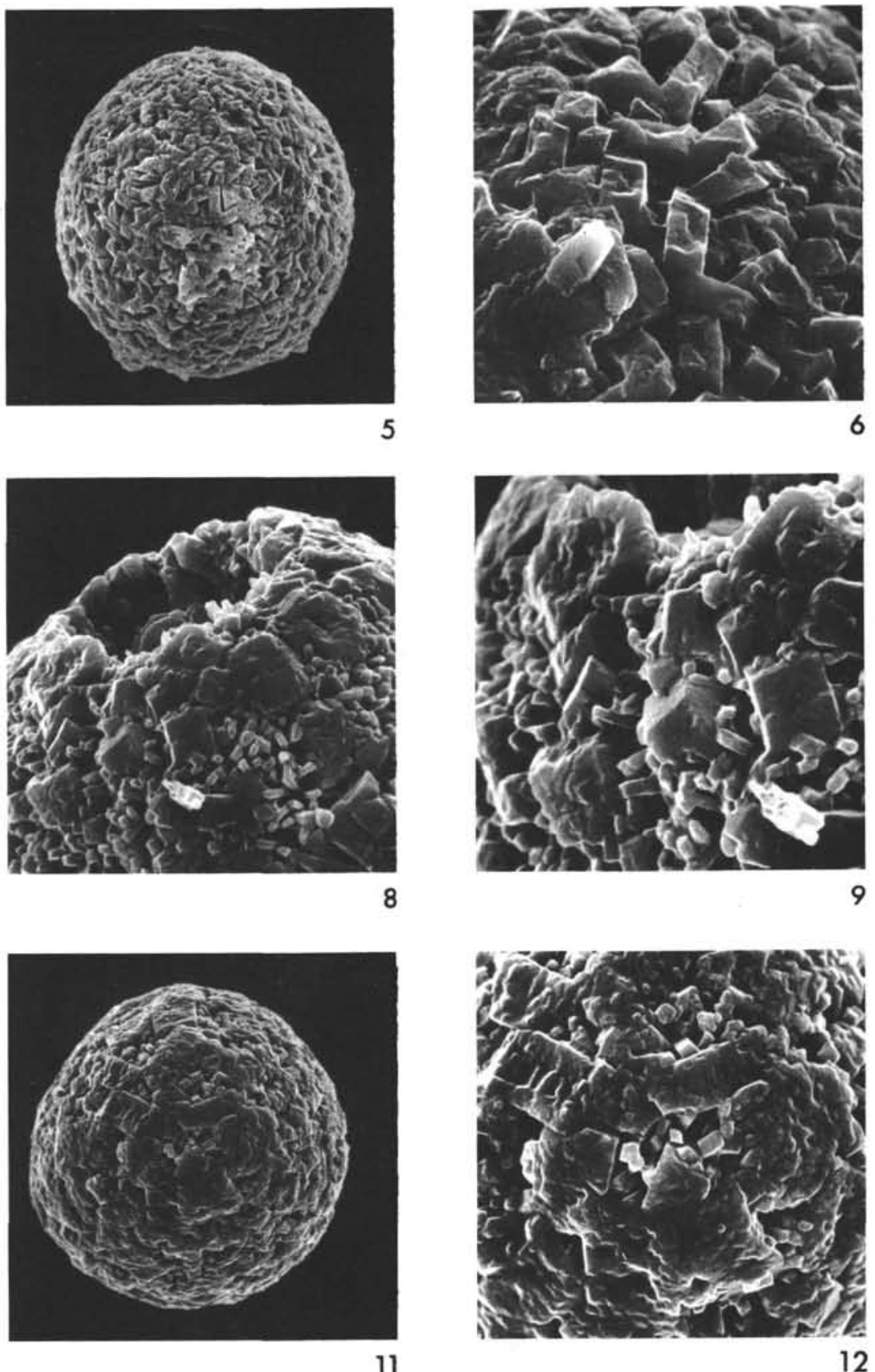


\section{PLATE 14}

Figures 1-3 Pithonella robinsoni, Sample 259-17-3, 38-40 cm.

1. Cross-section of wall and inside view of paratype, $\times 900$, C 29876.

2. Paratype with outer layer partially removed, exposing outer surface of inner layer, $\times 500, C$ 29879.

3. As Figure 2, $\times 1500, \mathrm{C} 29879$.

Figures 4-9 Pithonella sheilasantawae, Sample 259-17-3, 38-40 $\mathrm{cm}$.

4. Side/apertural view of paratype, $\times 700, C$ 29882.

5. Side view of paratype, $\times 650$, C 29883.

6. Outer surface of paratype Figure $5, \times 1500, \mathrm{C}$ 29883.

7. Partial view of apertural rim of holotype. Thick outer and thin inner layer clearly visible, $\times 2500, C$ 29880.

8. As Figure 7, different angle of view, $\times 1500, C$ 29880.

9. Cross section of wall and inside view of paratype, $\times 650$, C 29884 .

Figures 10-12 Pithonella francadecimae, Sample 259-12-2, 60-62 $\mathrm{cm}$.

10. Side/apertural view of paratype, $\times 650, \mathrm{C}$ 29888.

11. Side view of paratype Figure 10, $\times 650$, C 29888.

12. Side/apertural view of paratype, $\times 650$, C 29889. 
PLATE 14

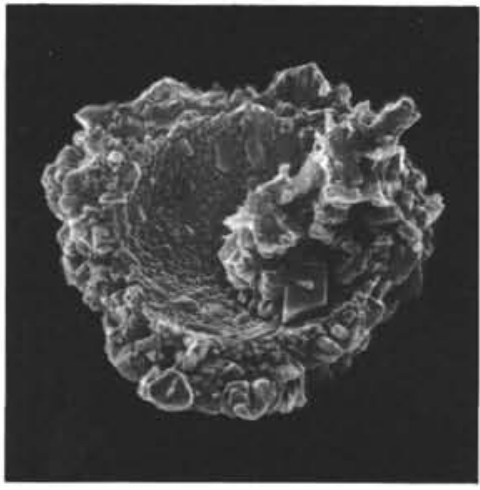

1

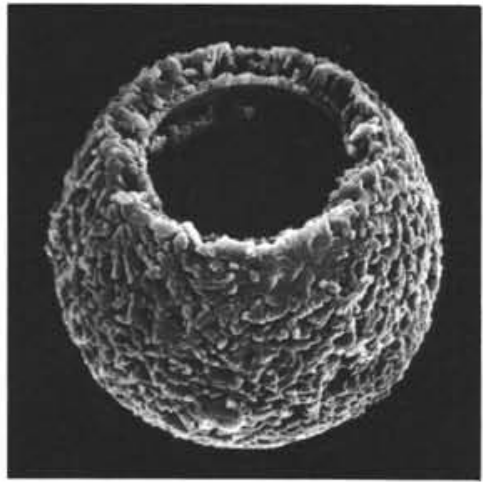

4
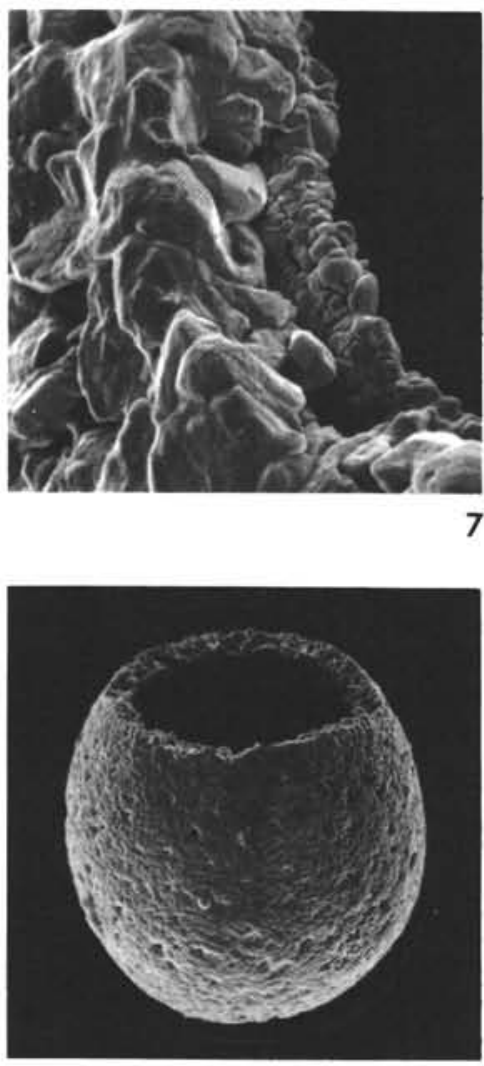

10
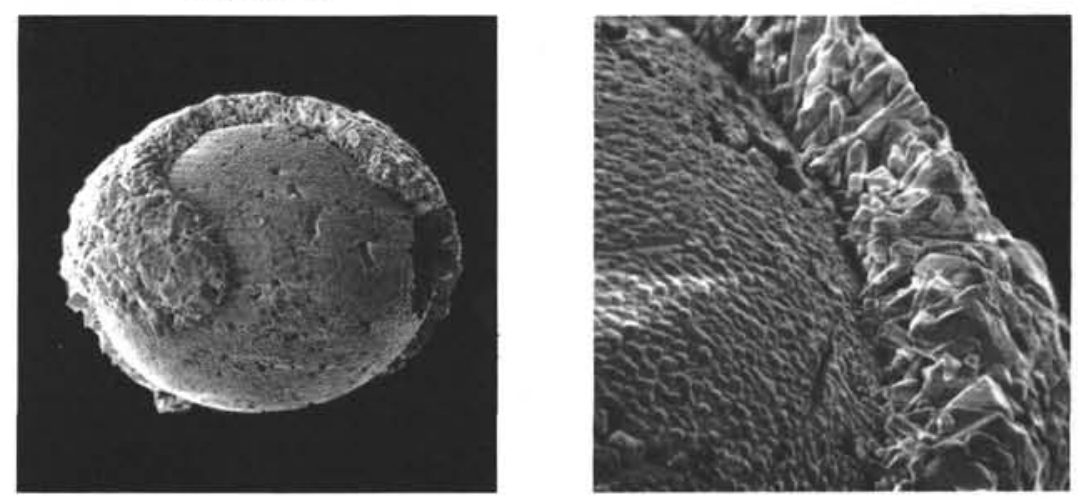

2

3

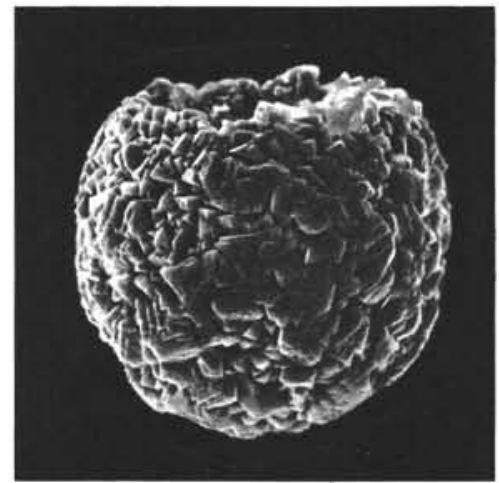

5
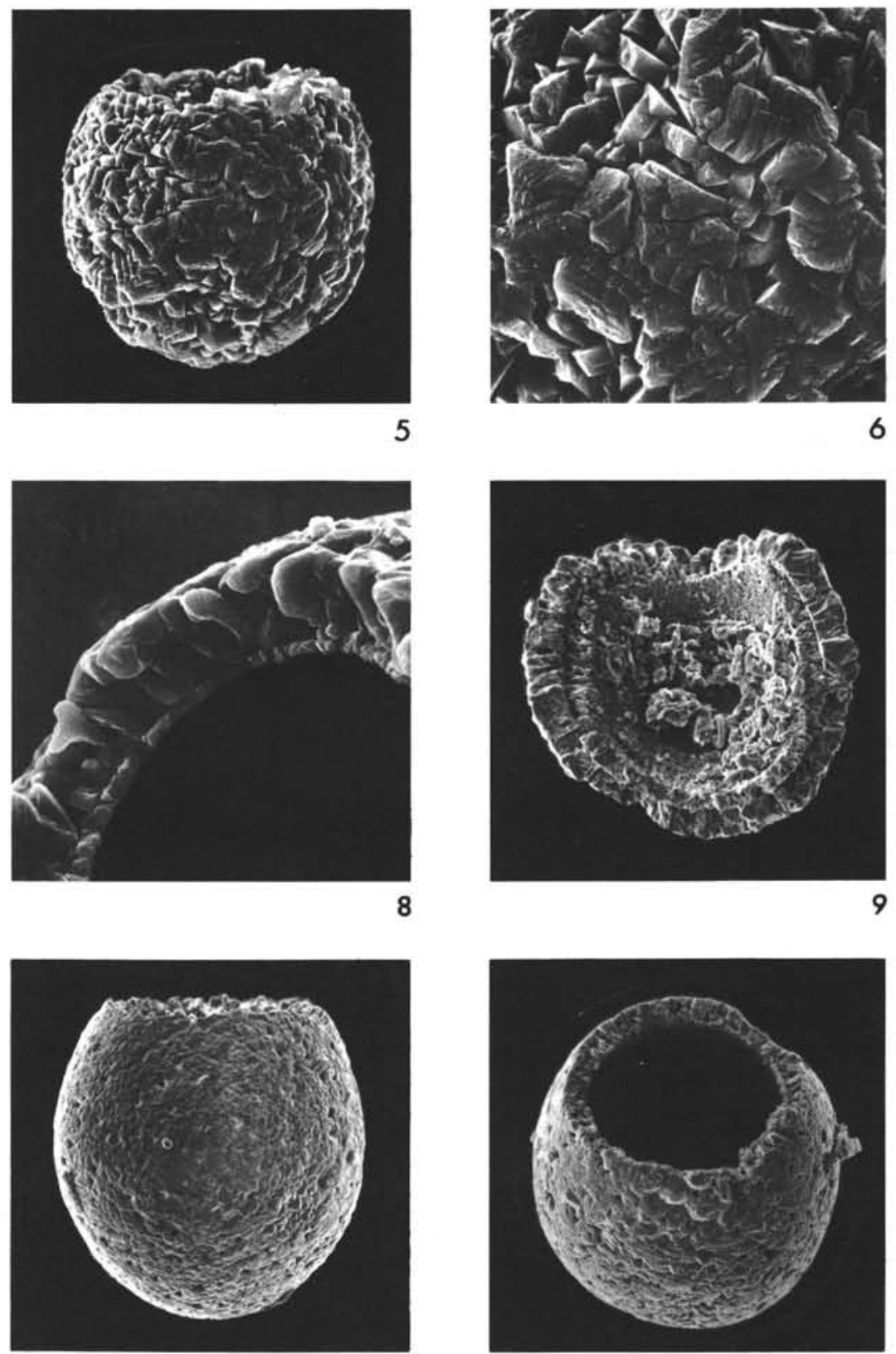

11 


\section{PLATE 15}

Figures 1-6 Pithonella francadecimae, Site 259.

1. Apertural rim of paratype Plate 14, Figure 12, Sample 12-2, 60-62 cm, ×3250, C 29889.

2. Cross-section of wall and inside view of paratype, Sample 12-2, 60-62 cm, ×1000, C 29886. 3 . Inner surface with irregular pores of paratype Figure 2, Sample 12-2, 60-62 cm, ×2500, C 29886. 4. Outer surface of paratype, Plate 14 Figure 12, Sample 12-2, 60-62 cm, ×2500, C 29889.

5. Paratype with operculum still loosely attached to and covering apertural area, Sample 14-3, 135$137 \mathrm{~cm}, \times 500$, C 29890.

6. As Figure 5, Sample 14-3, 135-137 cm, $\times 500, C$ 29890.

Figures 7-12 Pithonella heirtzleri, Site 259.

7. Side/apertural view of paratype, Sample 12-2, 60-62 cm, $\times 800$, C 29894.

8. Apertural area of paratype Figure 7, Sample 12-2, 60-62 cm, ×1500, C 29894.

9. Side/apertural view of paratype, Sample 13-2, 60-62 cm, ×650, C 29895.

10. Apertural area of paratype Figure 9, Sample 13-2, 60-62 cm, $\times 1500$, C 29895.

11. Distal view of paratype, Sample 12-2, 60-62 $\mathrm{cm}, \times 800$, C 29896.

12. As Figure 11, partial view, Sample 12-2, 60-62 $\mathrm{cm}, \times 2500$, C 29896. 
PLATE 15

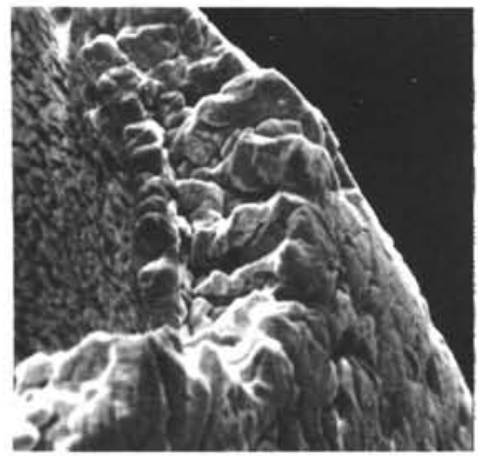

1

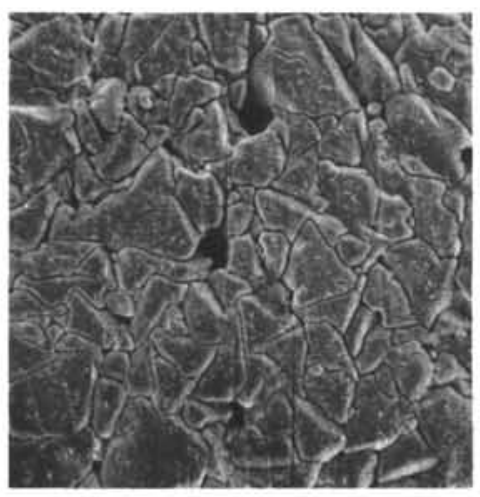

4

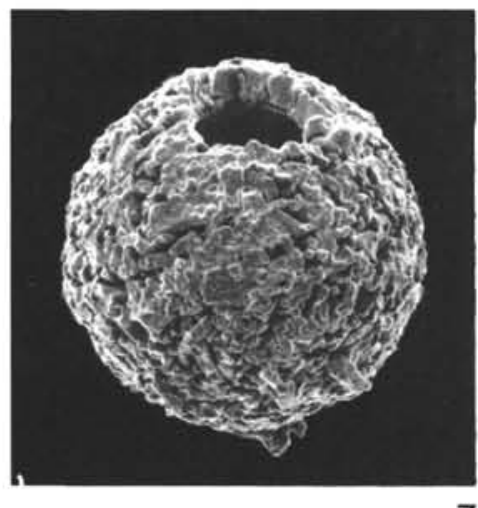

7

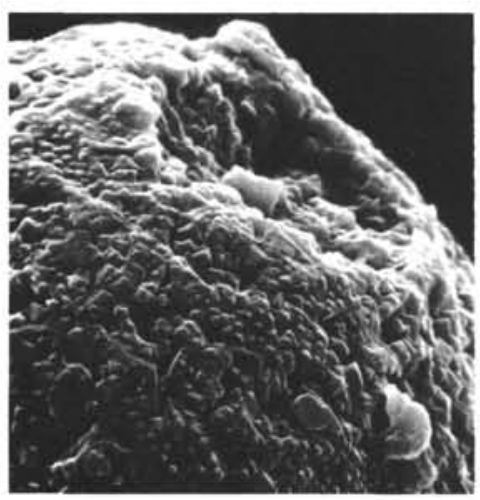

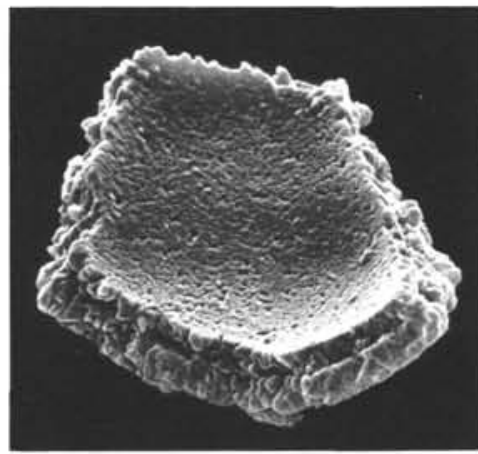

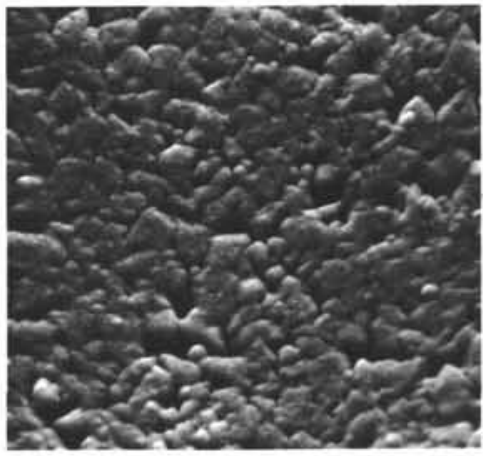

2
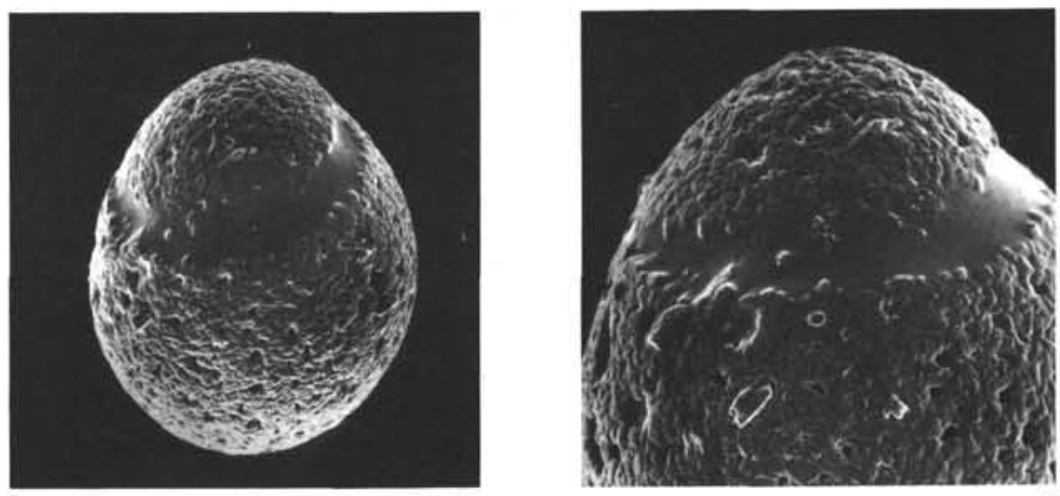

5

6
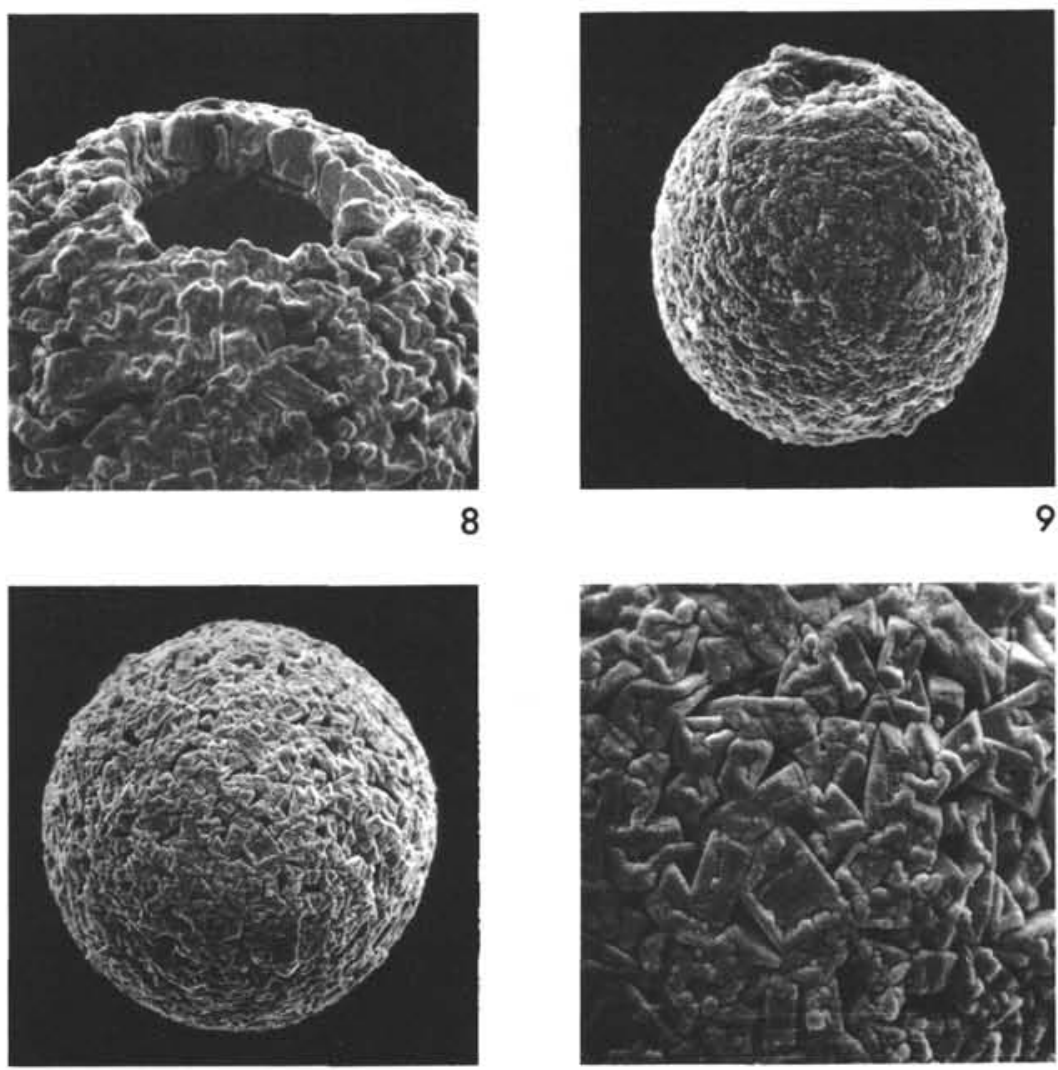

11 


\section{PLATE 16}

Figures 1-4 Pithonella heirtzleri, Site 259.

1. Cross-section of wall and inside view of broken paratype. The three layers, outer, middle, and inner, are clearly visible, Sample $12-2,60-62 \mathrm{~cm}$, $\times 600$, C 29897.

2. Partial view of paratype Figure 1, Sample 12-2, 60-62 cm, ×1500, C 29897.

3. Cross-section of wall and inside view of broken paratype. As in Figure 1, the three layers are clearly visible. In addition is partially exposed the outer surface of the middle layer (right side of figure), Sample 13-2, 60-62 $\mathrm{cm} \times 600$, C 29893.

4. Partial view of Figure 3, showing outer surfaces of outer- and middle layer, Sample 13-2, 60-62 cm, $\times 2500$, C 29893.

Figures 5-12 Pithonella veeversi, Sample 259-13-2, 60-62 cm.

5 . Side/apertural view of paratype, $\times 550, \mathrm{C}$ 29900.

6. Partial view of paratype of Figure $5, \times 1500, C$ 29900.

7. Cross-section of wall and inside view of broken paratype, $\times 1000$, C 29899 .

8. Partial view of inner surface of paratype Figure 7, $\times 5000$, C 29899.

9 . Side/apertural view of paratype, $\times 700, \mathrm{C}$ 29900.

10. Partial view of apertural area of paratype Figure $9, \times 2500$, C 29900.

11. Partial view of outer surface (middle part of specimen) of paratype Figure 9, ×3500, C 29900.

12. Partial view of outer surface (near apertural rim) of paratype Figure 9, ×4000, C 29900. 
PLATE 16
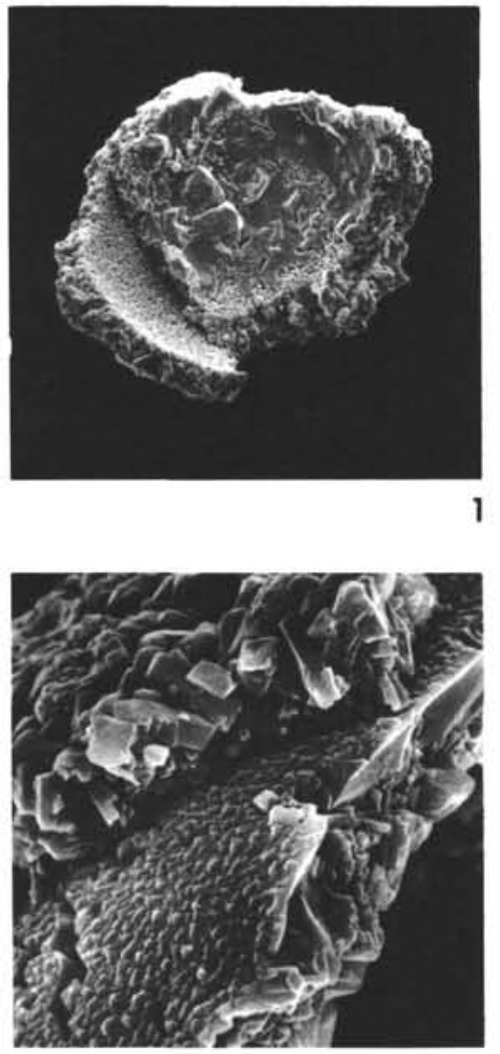

4

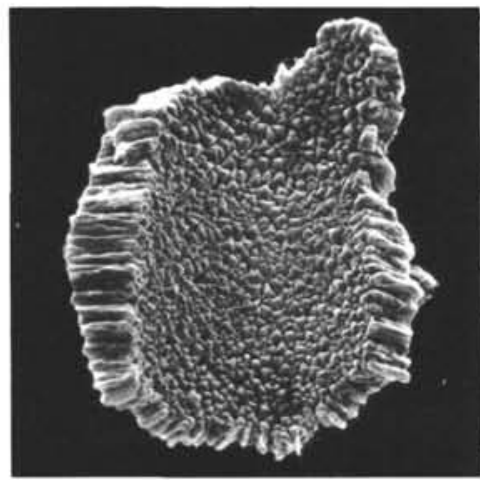

7

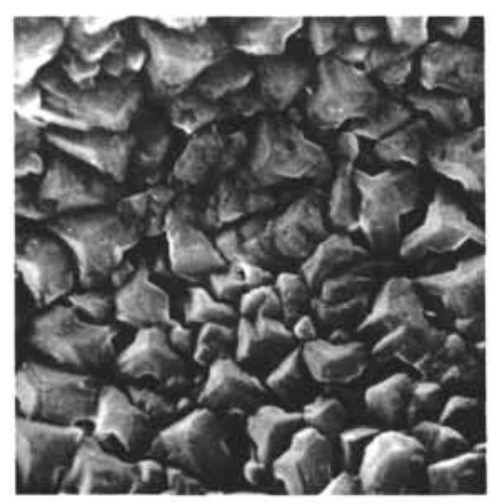

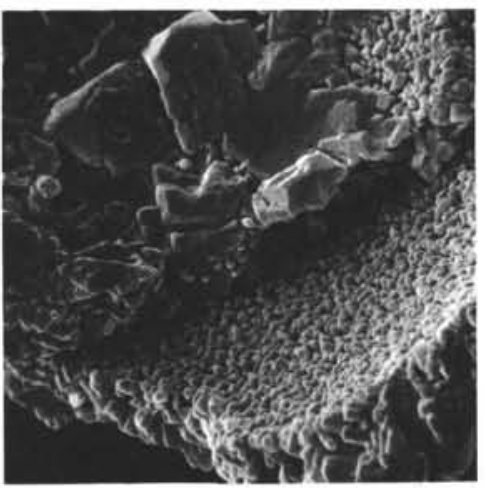

2
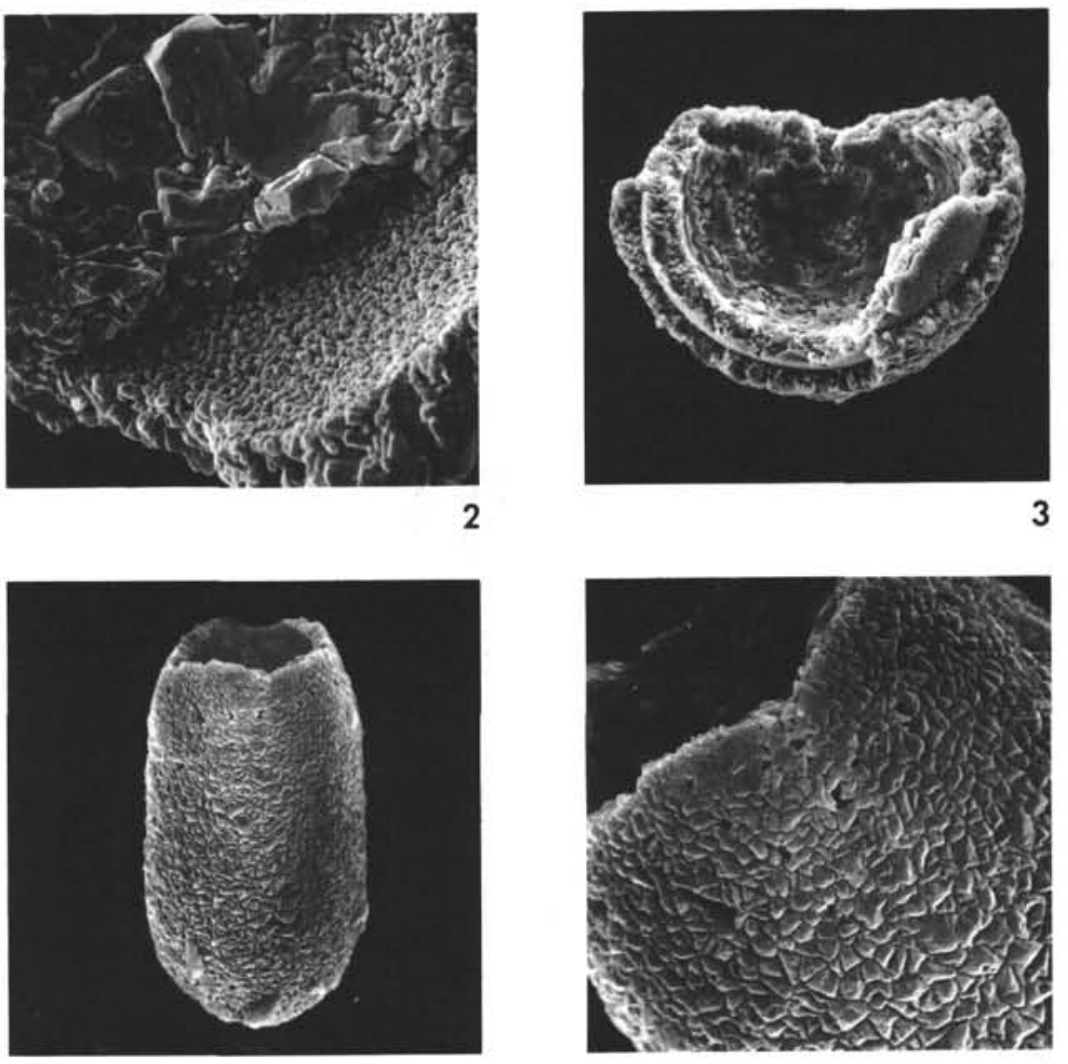

5
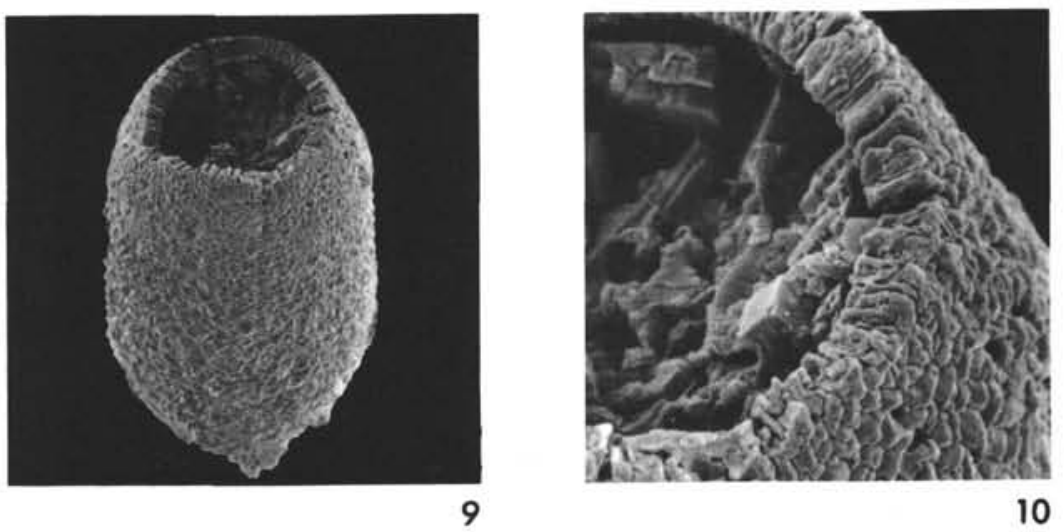

10
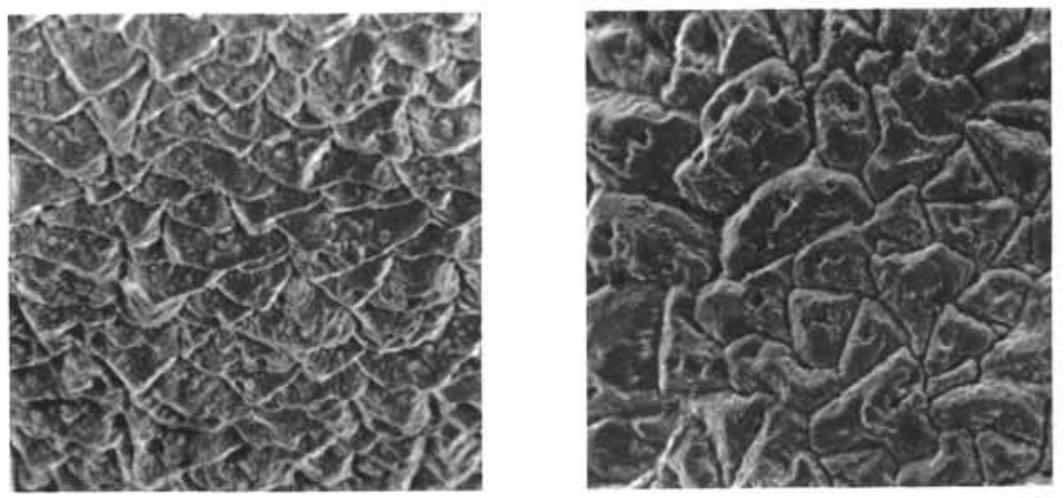

11 


\section{PLATE 17}

Figures 1-12 Pithonella quiltyi, Site 259.

1. Side/apertural view of paratype, Sample 12-2, 60-62 cm, ×750, C 29905.

2. Side/apertural view of paratype, Sample 13-2, 60-62 cm, ×750, C 29906.

3. Side view of paratype, Sample $13-2,60-62 \mathrm{~cm}$, $\times 700$, C 29907.

4. Side of paratype without aperture, Sample 122, 60-62 cm, ×700, C 29908.

5. Side view of paratype, Sample 13-2, $60-62 \mathrm{~cm}$, $\times 500$, C 29909.

6. Apertural view of paratype of Figure 5, Sample 13-2, 60-62 cm ×1000, C 29909.

7. Partial view of apertural rim of paratype of Figure 5, Sample 13-2, 60-62 cm, ×500, C 29909.

8. Side view of paratype without aperture, Sample 13-2, 60-62 cm ×700, C 29910.

9. Side view of paratype without aperture, Sample 17-2, 47-49 cm, ×500, C 29911.

10. Cross-section of wall and inside view, of broken paratype, Sample 17-2, 47-49 cm, $\times 900, C$ 29904.

11. Partial view of outer surface of paratype Figure 9, Sample 17-2, 47-49 cm, ×2500, C 29911. 12. Partial view of apertural rim of paratype Figure 1, Sample 12-2, 60-62 cm, ×2500, C 29905. 
PLATE 17
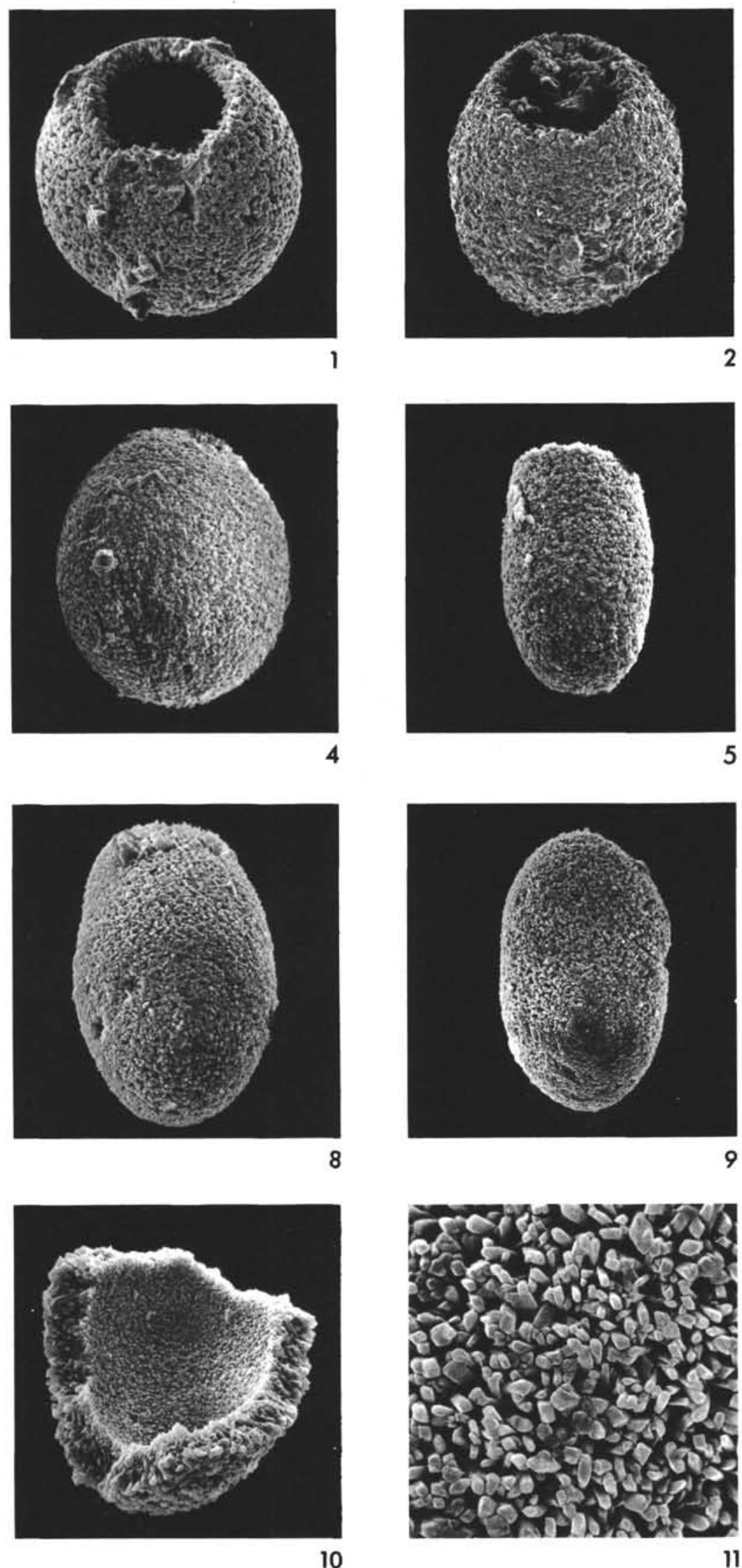

2

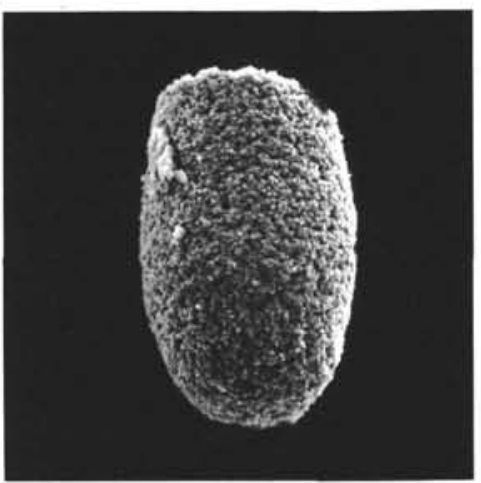

5

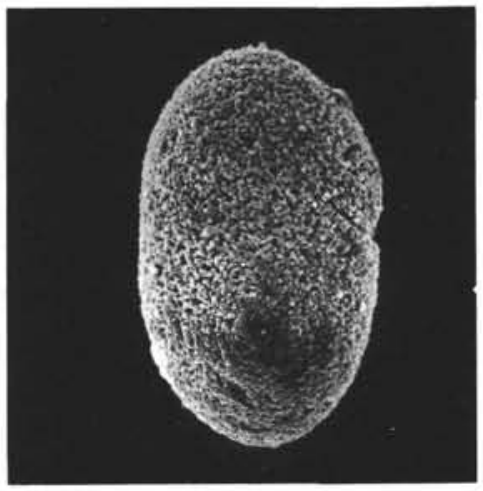

9

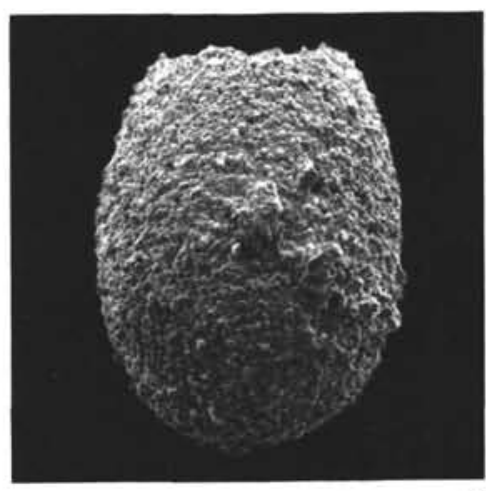

3
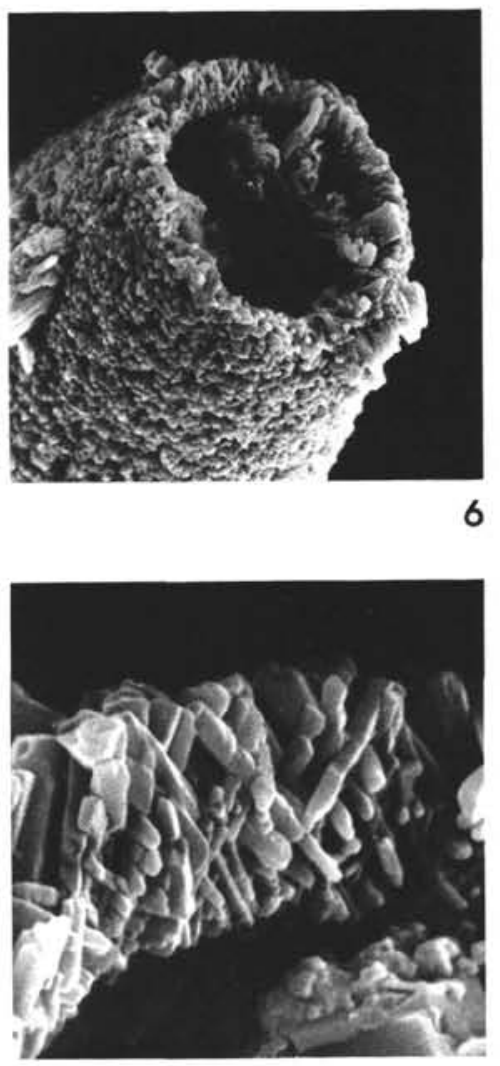

7
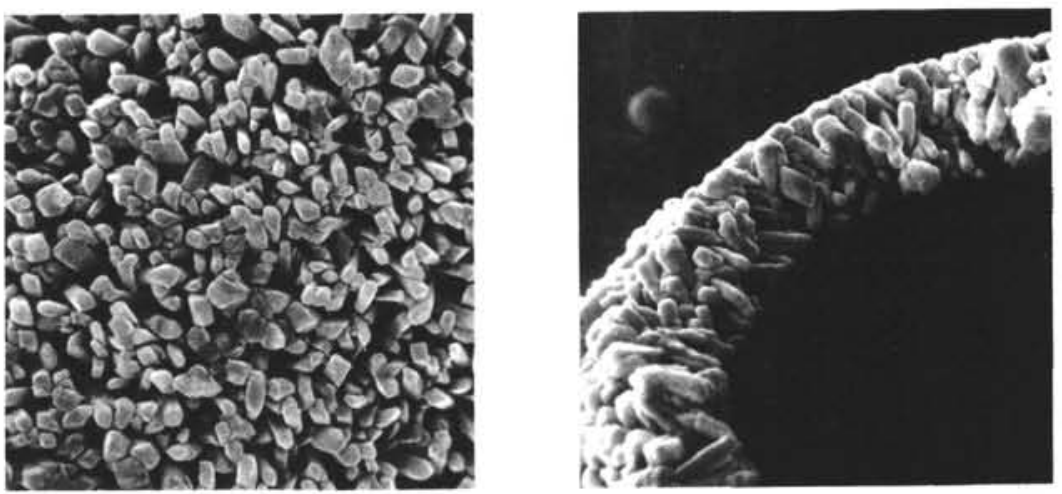

12 


\section{PLATE 18}

Figures 1-2 Pithonella johnstonei, Sample 260-6-1, 46-48 cm.

1. Apertural area of holotype (Plate 1, Figure 5), $\times 2500$, C 29912.

2. Cross-section of wall and inside view of broken paratype, X1100, C 29913.

Figures 3-9 Pithonella cooki, Sample 260-6-1, 46-48 cm.

3. Side view of paratype, $\times 550$, C 29917.

4. Partial view of outer surface of paratype Figure

$5, \times 2500$, C 29918 .

5. Side view of paratype, $\times 800$, C 29918.

6. Apertural area of paratype Figure $5, \times 2000, C$ 29918.

7. Partial view of outer surface of paratype, $\times 2500$, C 29919.

8. Cross-section of wall and inside view of paratype, $\times 500$, C 29916.

9. Apertural area of specimens transitioned between $P$. cooki and $P$. krasheninnikovi, $\times 1500$, C 29920.

Figures 10-12 Pithonella krasheninnikovi, Sample 260-6-1, 46-48 $\mathrm{cm}$.

10. Apertural area of holotype (Plate 7, Figure 1), $\times 1000$, C 29921.

11. Side view of paratype, $\times 450$, C 29922.

12. Side view of paratype, $\times 400$, C 29923. 
PLATE 18

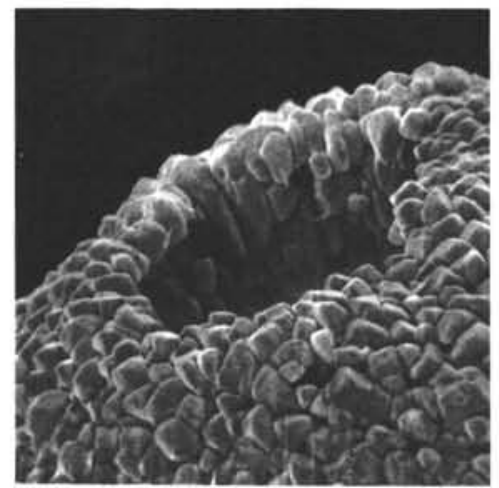

1

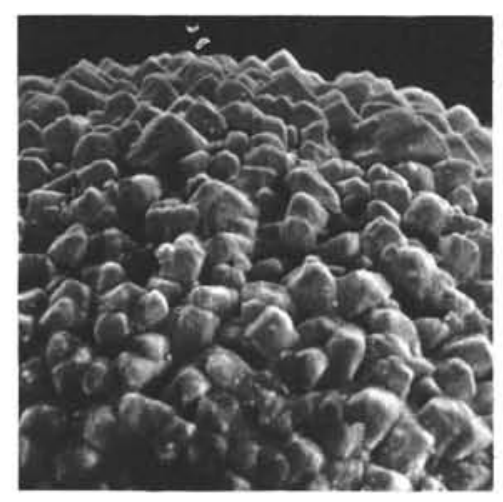

4

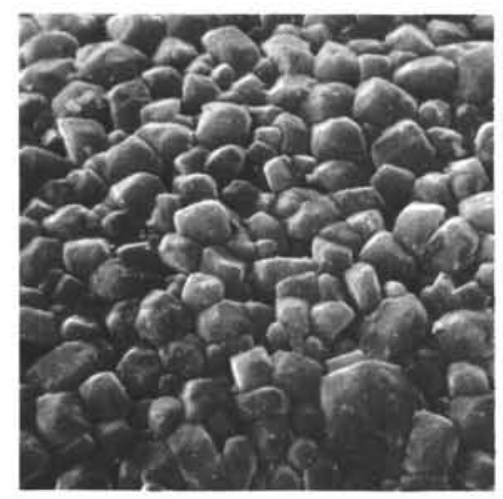

7

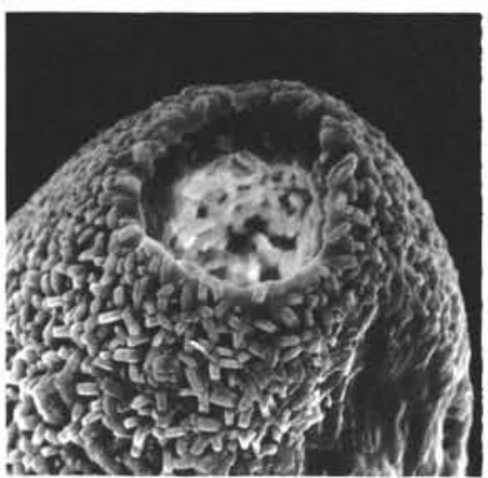

10
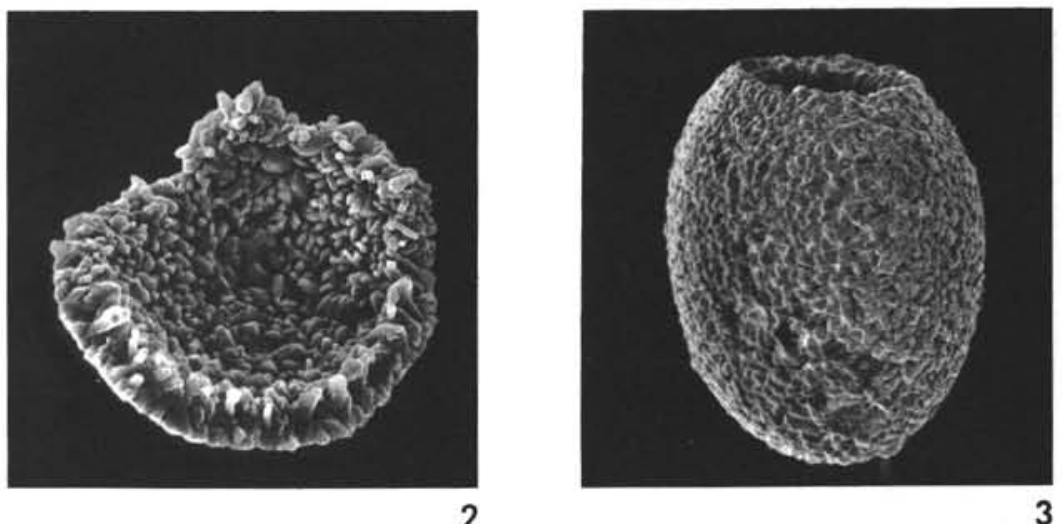

3
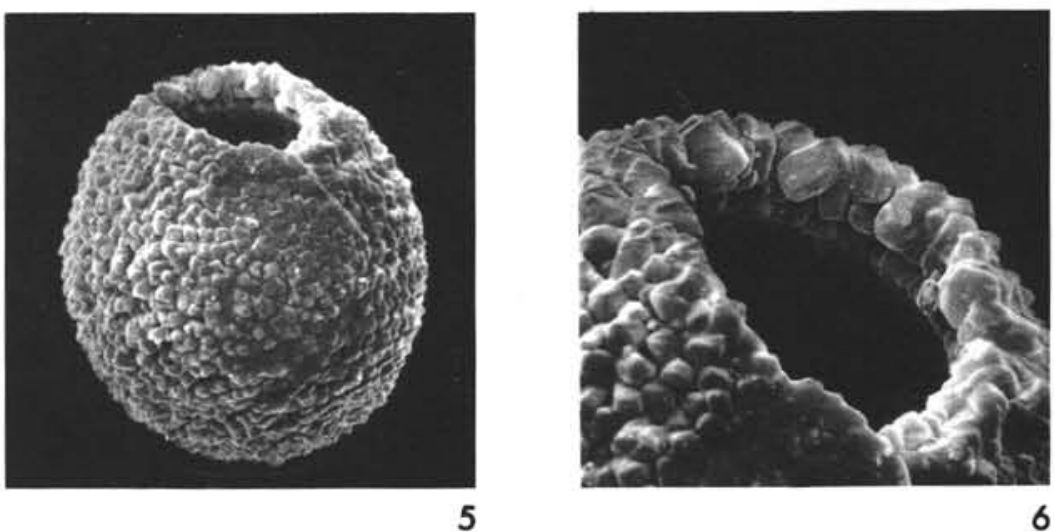

6

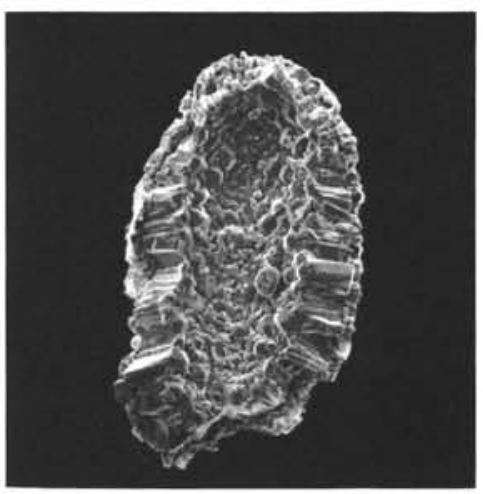

8

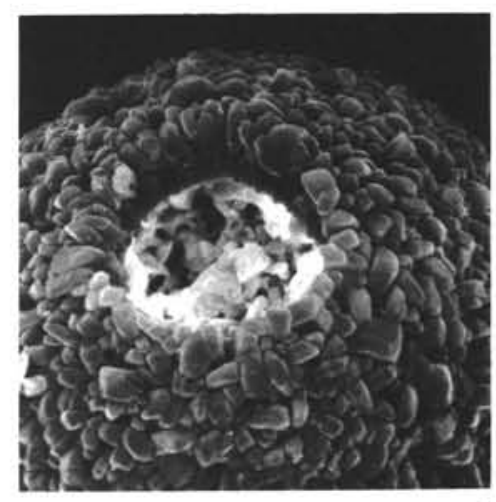

9

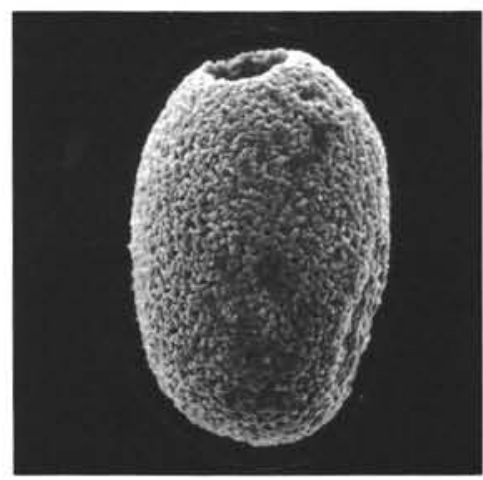

11

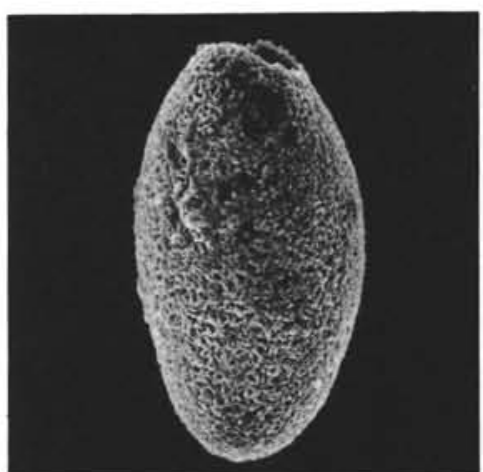

12 


\section{PLATE 19}

Figures 1-12 Pithonella krasheninnikovi, Sample 260-6-1, 46-48 $\mathrm{cm}$.

1. Side view of paratype with outer layer partially removed, and exposing inner layer, $\times 650$, C 29924.

2. Partial view of paratype Figure 1, on right:outer layer; on left: inner layer, $\times 1500, \mathrm{C}$ 29924.

3. Partial view of paratype Figure 1: outer layer, $\times 2500$, C 29924.

4. Partial view of paratype Figure 1, left: outer layer; right: inner layer, ×2500, C 29924.

5 . Side view of paratype with outer layer partially removed, exposing inner layer, $\times 400$, C 29925.

6. Partial view of paratype Figure 5: inner layer covered by outer layer on lower left and upper right, $\times 1500$, C 29925 .

7. Side view of paratype without aperture and only inner layer preserved, $\times 500$, C 29926.

8. Partial view of outer surface of paratype Figure 7 with crystal faces well developed, $\times 1500$, C 29926.

9. Partial view of surface of outer layer of specimen transitioned between $P$. cooki and $P$. krasheninnikovi, $\times 2500$, C 29927.

10. Side view of paratype with aperture and only inner layer preserved, $\times 500$, C 29928.

11. Partial view of surface of inner layer of paratype Figure 10, ×5000, C 29928.

12. Cross-section of wall and inside view of paratype, $\times 1000$, C 29923. 
PLATE 19
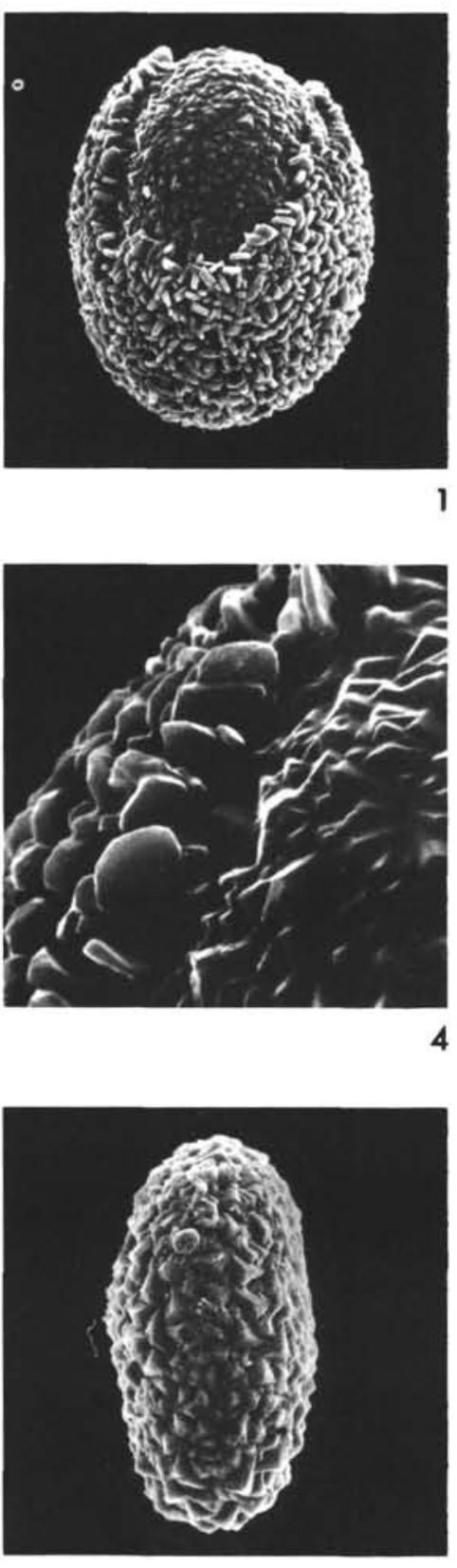

7

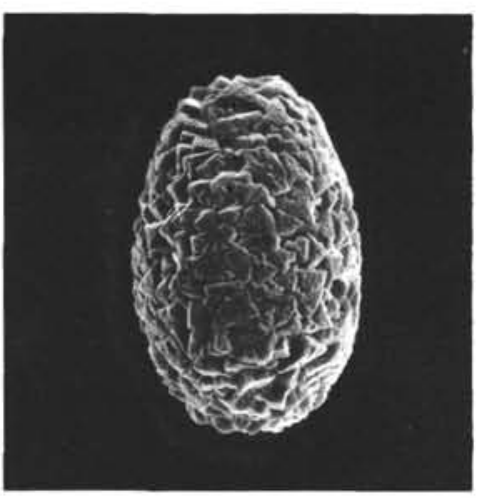

10

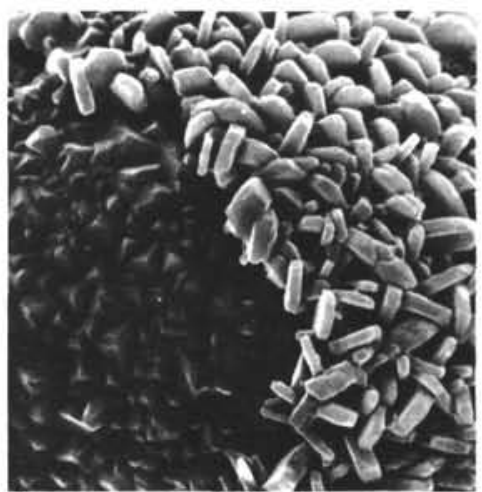

2

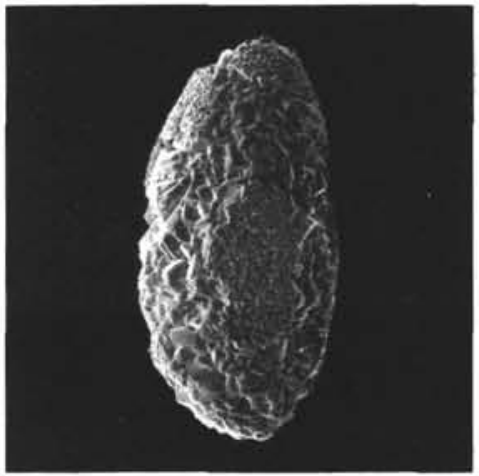

5
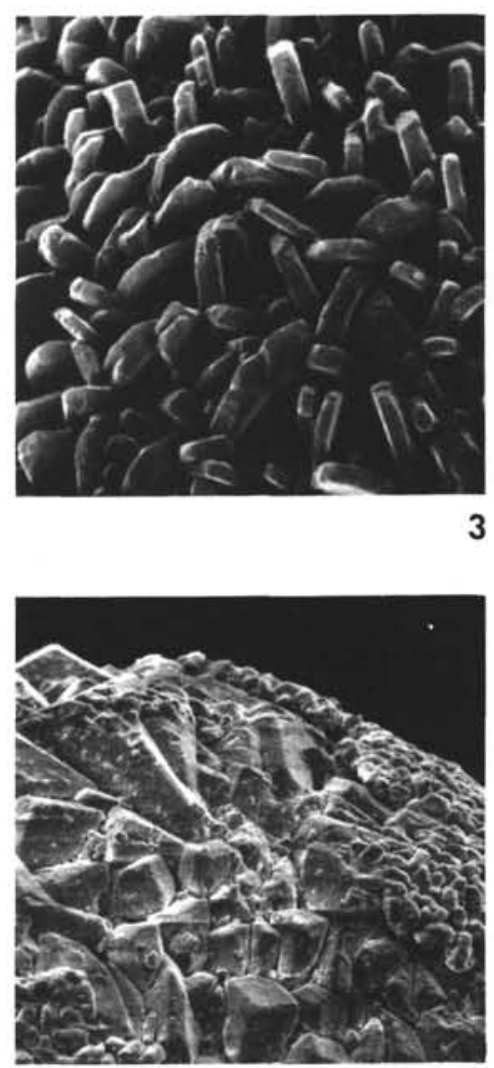

6
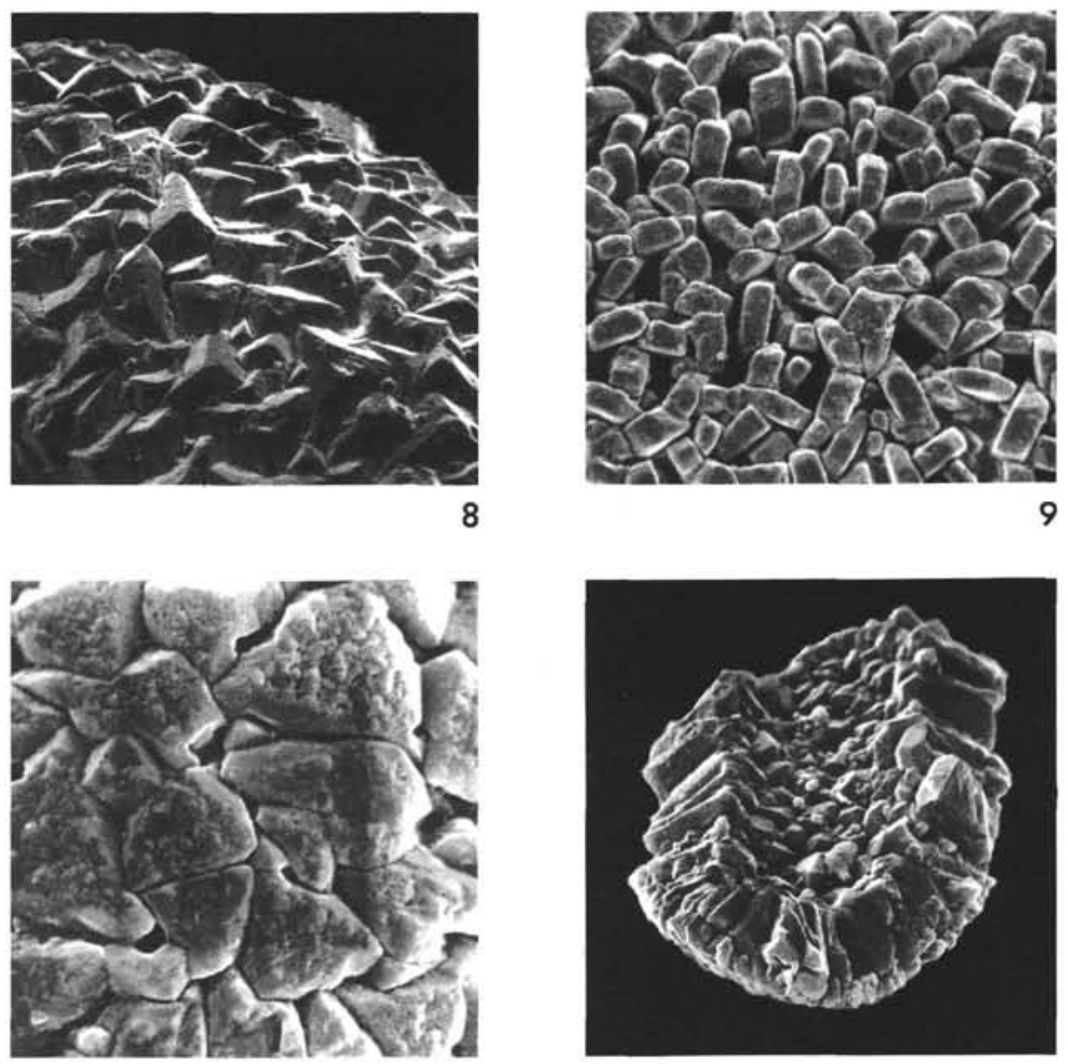


\section{PLATE 20}

Figures 1-2 Pithonella krasheninnikovi, Sample 260-6-1, 46-48 $\mathrm{cm}$.

1. Side view of paratype with outer layer removed, $\times 500$, C 29929.

2. Apertural area of paratype Figure $1, \times 1500, C$ 29929.

Figures 3-4 Pithonella cf. krasheninnikovi, Sample 260-6-1, 46$48 \mathrm{~cm}$.

3. Side view of specimen with outer layer crystals similar as in P. krasheninnikovi but with few larger, more massive crystals interspaced, $\times 600$, C 29930. 4. Partial view of specimen Figure 4 with few, distically larger crystals, ×1500, C 29930 .

Figures 5-6 Pithonella sp. C, Sample 260-6-1, 46-48 cm.

5 . Side/apertural view of specimen whose wall is formed by crystals of strongly varying size and shape, X550, C 29933.

6. Apertural area of specimen Figure 5, $\times 1500, \mathrm{C}$ 29933.

Figures 7-8 Pithonella sp. D, Sample 260-6-1, 46-48 cm

7. Side view of specimen, $\times 450$, C 29934.

8. Apertural area of specimen Figure 5, showing large crystals forming apertural rim, $\times 1000, C$ 29934.

Figure 9 Pithonella sp. B, Sample 260-6-1, 46-48 cm.

9. Apertural area of specimen (Plate 7, Figure 6), $\times 1500$, C 29931.

Figures 10-12 Pithonella sp. A, Sample 263-3, CC.

10. Apertural area of specimen Figure 11 (same specimen: Plate 7, Figure 9), ×1000, C 29932.

11. Side/distal view of specimen, $\times 650$, C 29932 .

12. Distal area of specimen Figure 11 with small, circular opening, $\times 650$, C 29932. 
PLATE 20

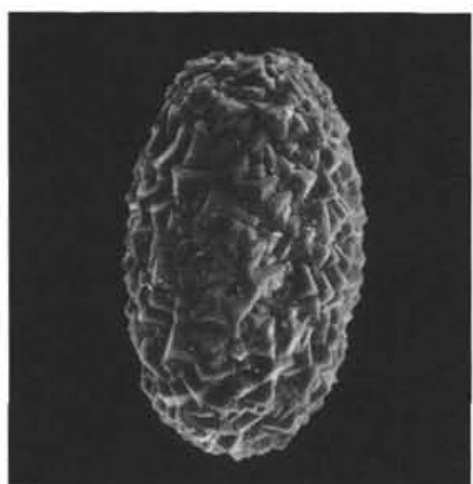

1

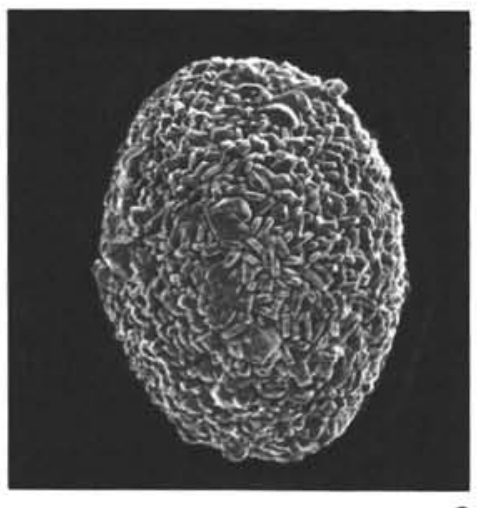

3
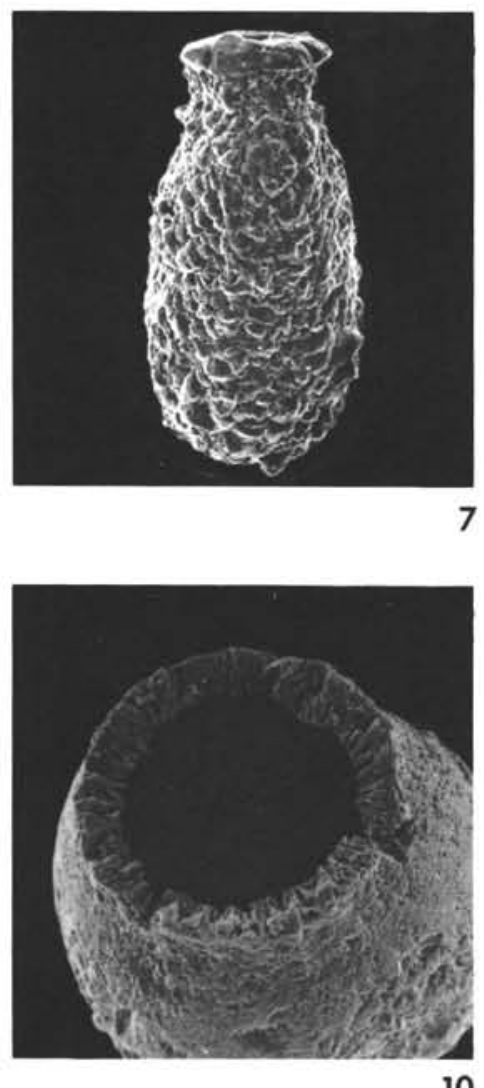
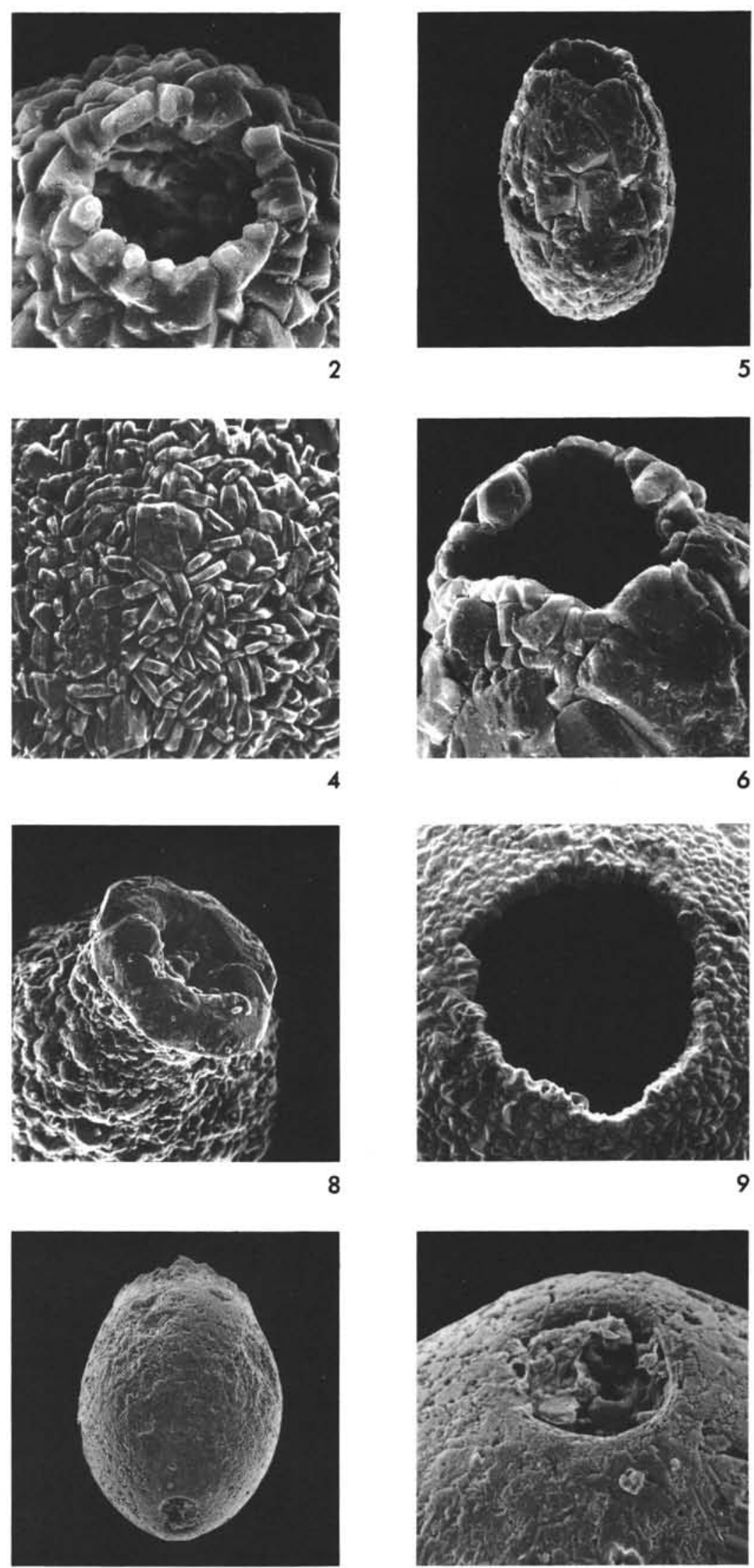

11 
PLATE 21

Higher enlargements of holotypes figured on Plates 1 and 2.

Figure 1 Pithonella carteri, holotype, ×1600, C 29809.

Figure 2 Pithonella mcnighti, holotype, $\times 1450$, C 29814.

Figure 3 Pithonella thayeri, holotype, $\times 1300$, C 29820.

Figure 4 Pithonella helentappanae, holotype, $\times 1300, C$ 29834.

Figure 5 Pithonella nonarenzae, holotype, $\times 1400$, C 29841 .

Figure 6 Pithonella patriciagreeleyae, holotype, $\times 1600, \mathrm{C}$ 29809. 
PLATE 21
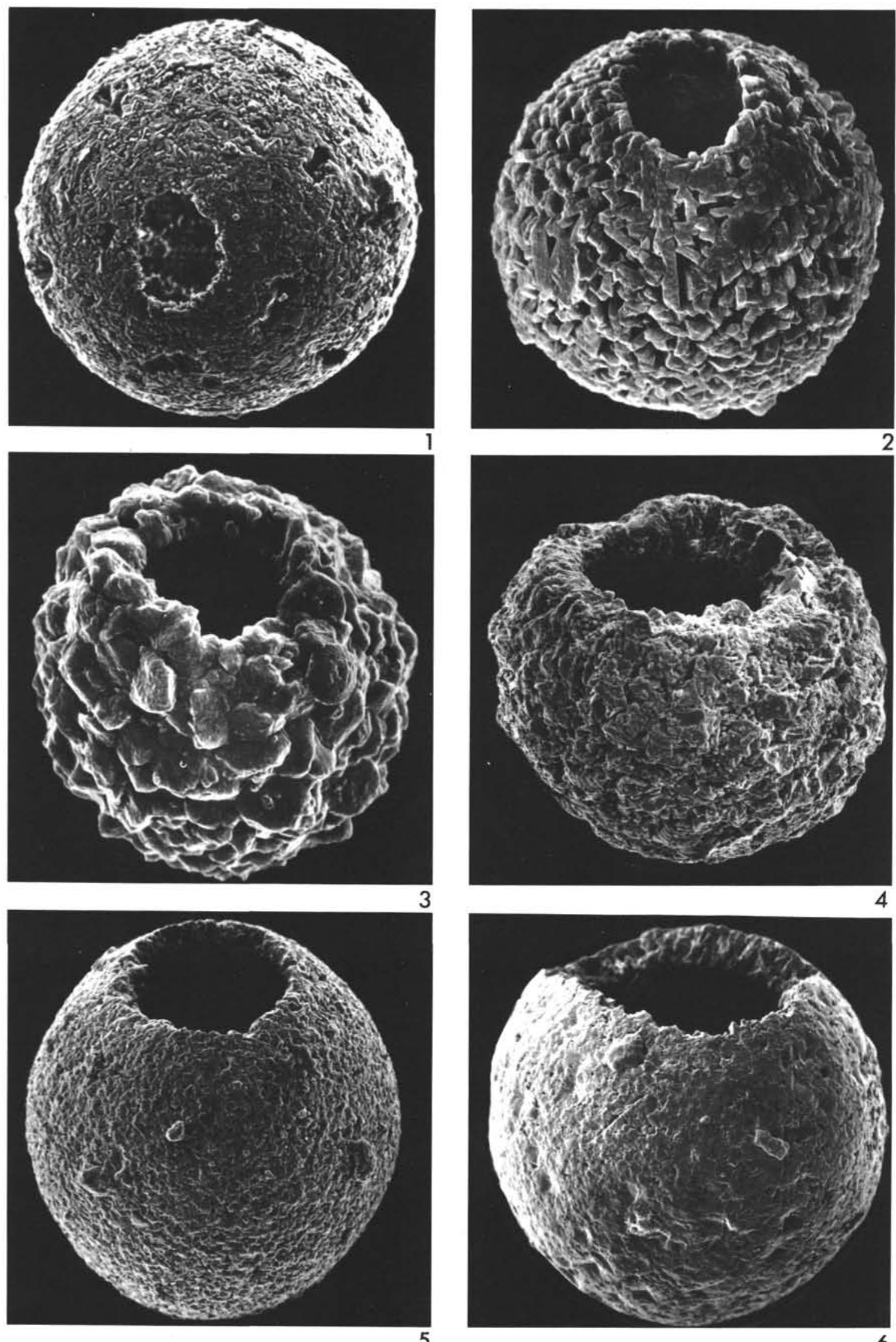
PLATE 22

Higher enlargements of holotype figured on Plates 3 and 4.

Figure 1 Pithonella loeblichi, holotype, ×1350, C 29854.

Figure 2 Pithonella rockeri, holotype, $\times 1350$, C 29859.

Figure 3 Pithonella gustafsoni, holotype, ×1500, C 29863.

Figure 4 Pithonella edgari, holotype, $\times 1500$, C 29870.

Figure 5 Pithonella robinsoni, holotype, $\times 1300$, C 29875.

Figure 6 Pithonella sheilasantawae, holotype, $\times 1350, \mathrm{C}$ 29880. 
PLATE 22
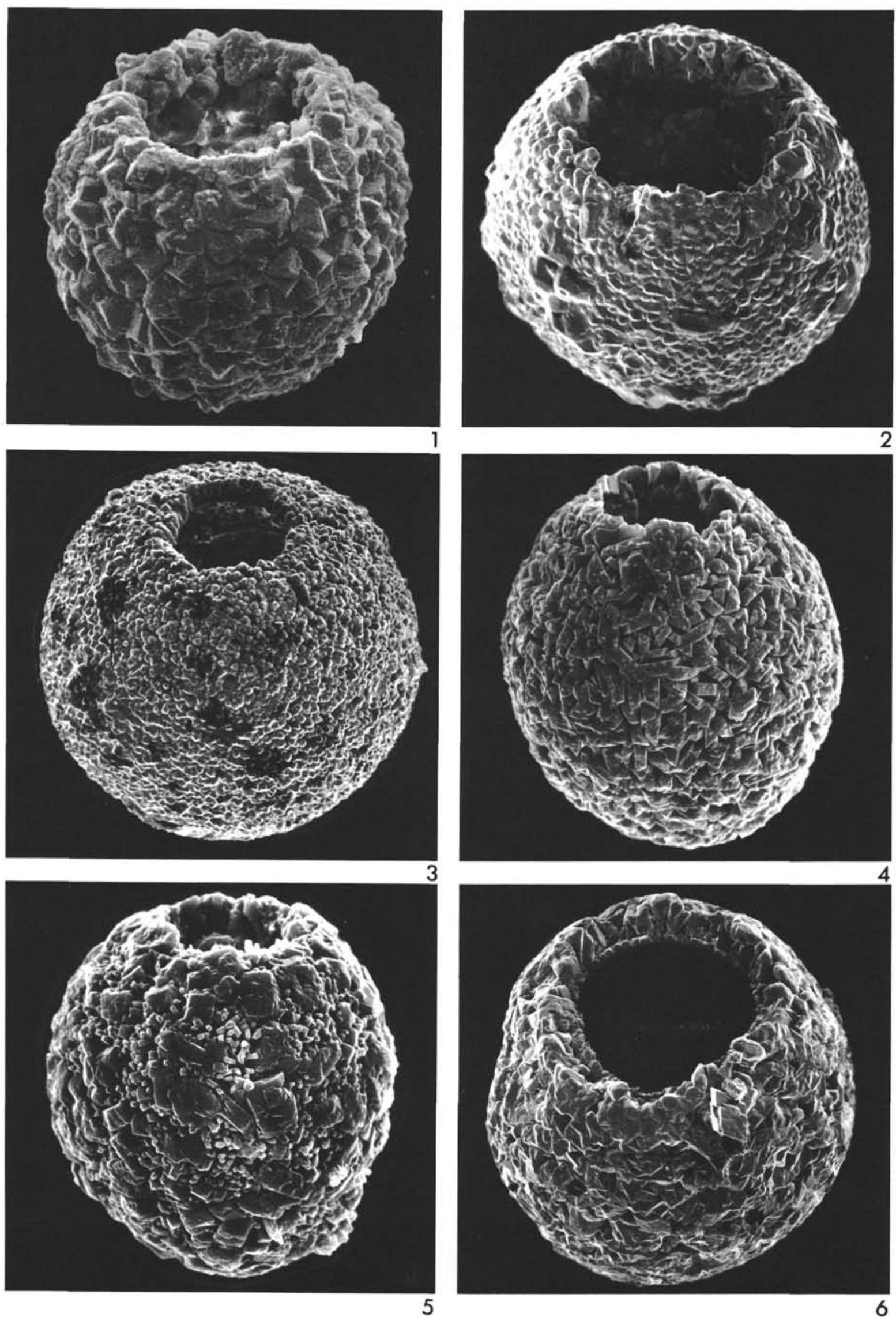
PLATE 23

Higher englargements of holotype figured on Plates 5 and 6.

Figure 1

Pithonella francadecimae, holotype, $\times 1200, C$ 29885.

Figure 2 Pithonella heirtzleri, holotype, $\times 1350$, C 29891 .

Figure 3 Pithonella veeversi, holotype, × 1000, C 29898.

Figure $4 \quad$ Pithonella quiltyi, holotype, $\times 1050$, C 29901.

Figure $5 \quad$ Pithonella johnstonei, holotype, $\times 1600$, C 29912.

Figure $6 \quad$ Pithonella cooki, holotype, ×950, C 29914. 
PLATE 23
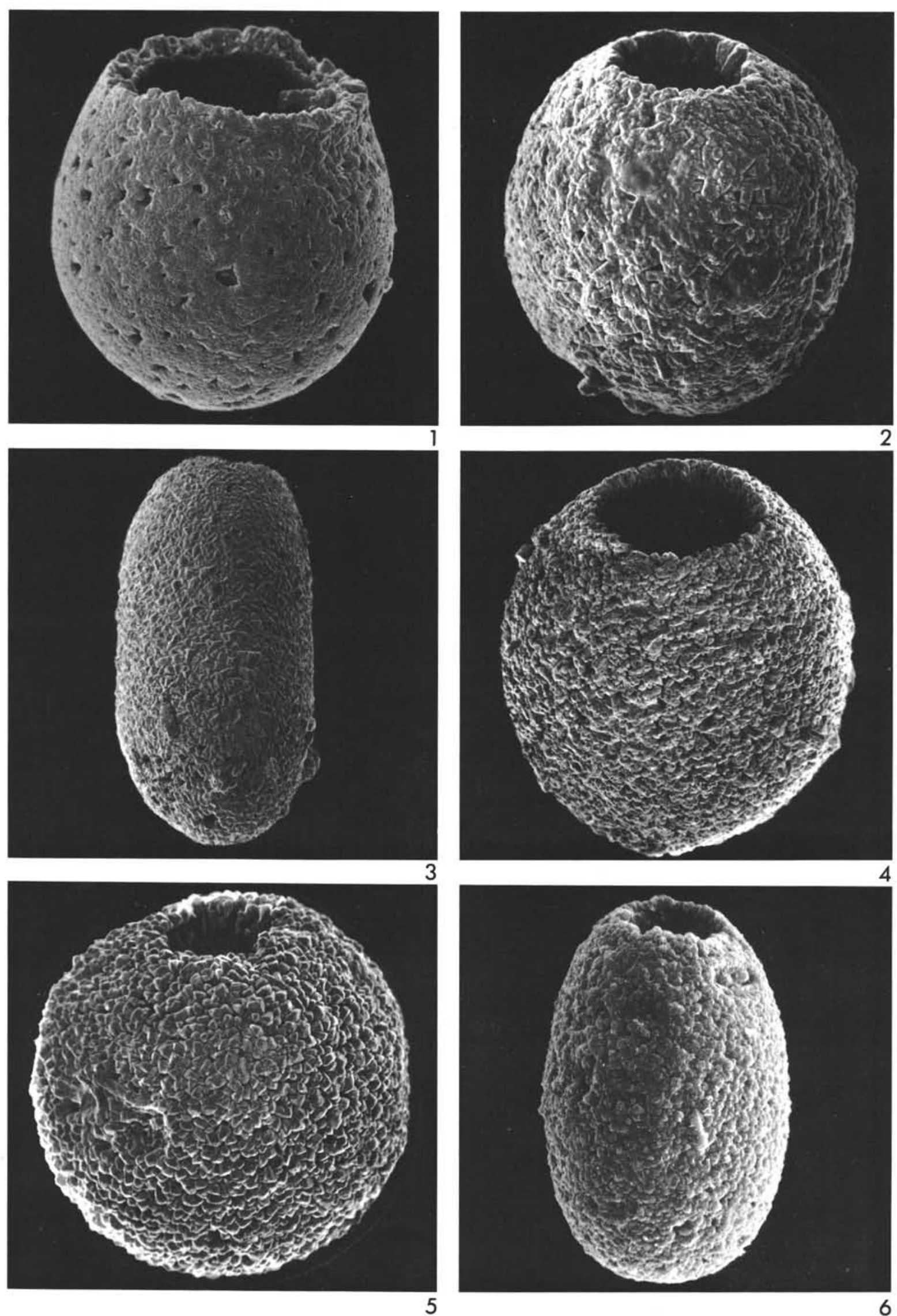


\section{PLATE 24}

Higher enlargements of holotype and paratype of Pithonella krasheninnikovi, and of types in open nomenclature, figured on Plates 7 and 20

Figure 1 Pithonella krasheninnikovi, holotype, $\times 650, C$ 29921.

Figure 2 Pithonella krasheninnikovi, paratype, $\times 900, C$ 29929.

Figure 3 Pithonella sp. B, ×1250, C 29931.

Figure $4 \quad$ Pithonella sp. A, ×1200, C 29932.

Figure 5 Pithonella sp. C, ×1000, C 29933.

Figure $6 \quad$ Pithonella sp. D, ×750, C 29934. 
PLATE 24
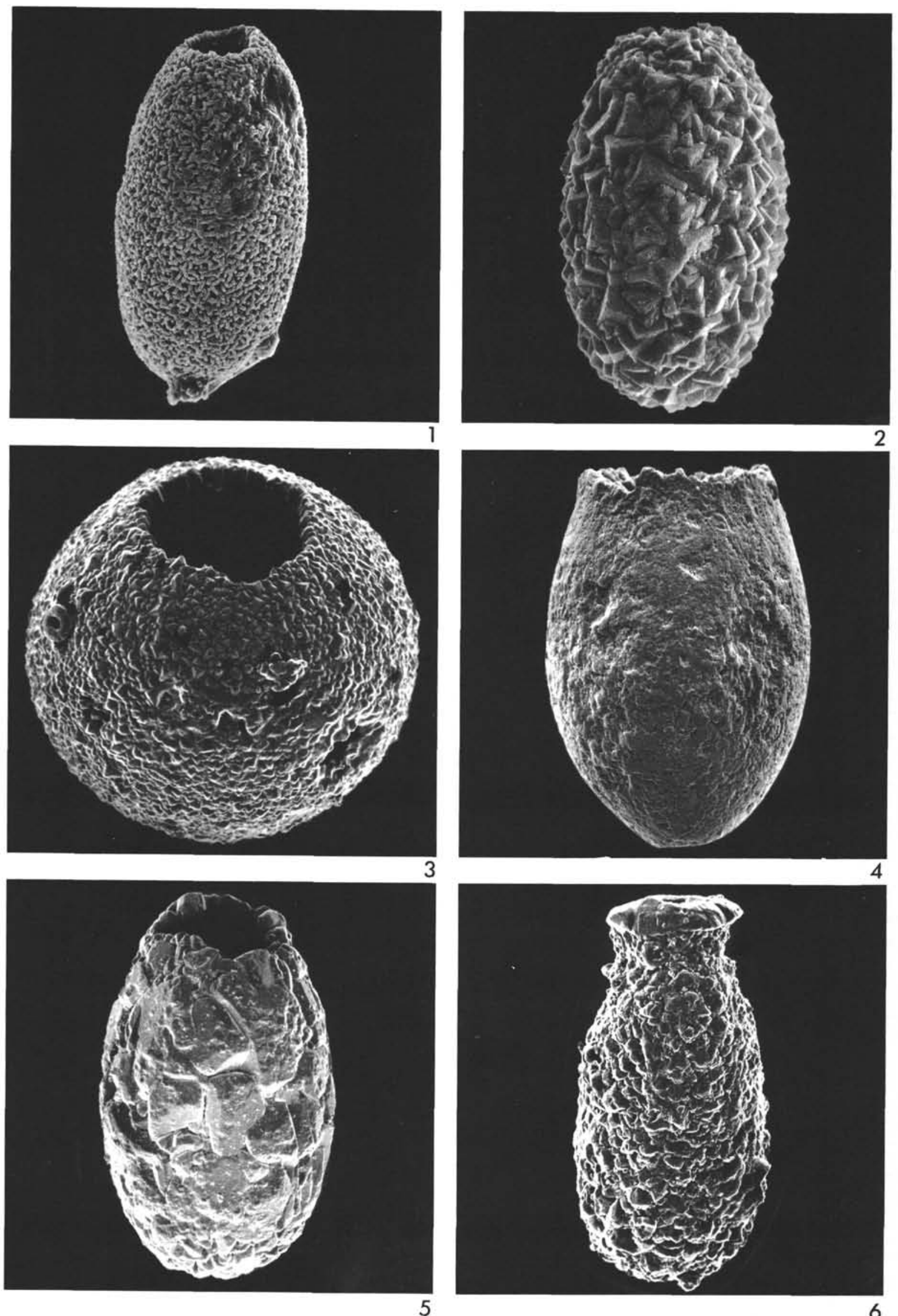